UNIVERSIDADE DE SÃO PAULO

FACULDADE DE FILOSOFIA, LETRAS E CIÊNCIAS HUMANAS

DEPARTAMENTO DE LETRAS MODERNAS

PROGRAMA DE PÓS-GRADUAÇÃO EM ESTUDOS LINGÜÍSTICOS E LITERÁRIOS EM INGLÊS

\author{
CLAUDIA MARIA AFFONSO
}

\title{
PAMELA \\ UM ESTUDO SOBRE A RELAÇÃO PERSONAGEM / ESPAÇO NO ROMANCE INGLÊS DO SÉCULO XVIII
}

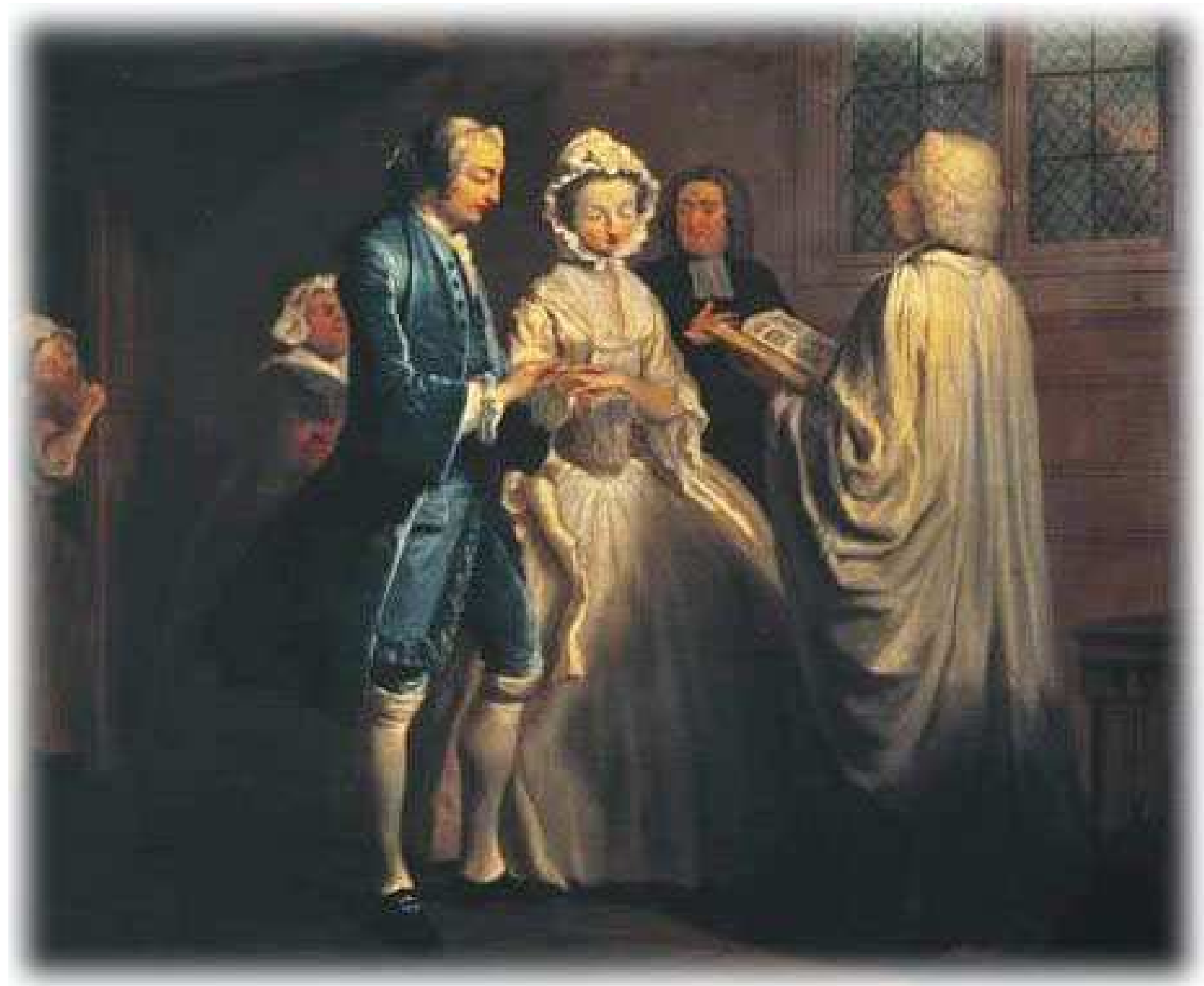

v. 1

São Paulo 
UNIVERSIDADE DE SÃO PAULO

FACULDADE DE FILOSOFIA, LETRAS E CIÊNCIAS HUMANAS

DEPARTAMENTO DE LETRAS MODERNAS

PROGRAMA DE PÓS-GRADUAÇÃO EM ESTUDOS LINGÜÍSTICOS E LITERÁRIOS

EM INGLÊS

\title{
PAMELA \\ UM ESTUDO SOBRE A RELAÇÃO PERSONAGEM / ESPAÇO NO ROMANCE INGLÊS DO SÉCULO XVIII
}

\author{
Claudia Maria Affonso
}

Dissertação apresentada ao Programa de Pós-Graduação em Estudos Lingüísticos e Literários em Inglês do Departamento de Letras Modernas da Faculdade de Filosofia, Letras e Ciências Humanas da Universidade de São Paulo, para a obtenção do título de Mestre em Letras.

Orientador: Profa. Dra. Sandra Guardini Teixeira Vasconcelos

v. 1

São Paulo

2009 


\section{AGRADECIMENTOS}

À Profa. Dra. Sandra Guardini Teixeira Vasconcelos, professora titular da Faculdade de Filosofia, Letras e Ciências Humanas da USP, pela orientação e por ter tornado esta pesquisa possível.

À minha família: meu pai, que me mostrou o valor do conhecimento; minha mãe, que me ensinou o gosto pela literatura e a apreciar a beleza da vida; meu marido, pela paciência e pelo apoio silencioso e amoroso; e, minha irmã, que, por ser arquiteta, me instruiu na observação do espaço.

Aos professores de minha banca de qualificação, Prof. Dr. Antonio Dimas e Prof. Dr. Daniel Puglia da USP, pelos valiosos comentários.

Aos meus colegas do grupo de estudos da Profa. Sandra, pelas inúmeras tardes de sexta-feira dedicadas à difusão do conhecimento.

Aos funcionários da biblioteca da Faculdade de Filosofia, Letras e Ciências Humanas da USP, pela eficiência na manutenção de um centro do saber sem o qual esta pesquisa não teria sido possível.

A todos aqueles que, de uma maneira ou outra, contribuíram para o desenvolvimento deste estudo.

Imagem da capa: "Pamela is married". Joseph Highmore. Óleo sobre tela, 1743-4. Acervo da Tate Gallery, Londres. Disponível em: <http://www.janeausten.co.uk/graphics/pamelawedding.jpg> Acesso em: 11 jul. 2009. 


\section{ÍNDICE}

RESUMO

ABSTRACT

1. INTRODUÇÃO

2. PAMELA: A RELAÇÃO PERSONAGEM / ESPAÇO NO ROMANCE

2.1. A caracterização do espaço: a mansão de Bedfordshire

2.2. A ênfase no espaço interior

2.3. A centralidade do espaço em Pamela 26

2.4. Narrador e modo narrativo 34

2.5. Um embate no interior da mansão de Bedfordshire: carta XV 50

2.6. A caracterização das personagens: Pamela e Mr B. 62

2.7. A caracterização do espaço: a mansão de Lincolnshire 67

2.8. A importância do espaço exterior 73

2.9. Uma cena no exterior da mansão de Lincolnshire: às margens do lago 79

2.10. Considerações finais

3. CONCLUSÃO

4. APÊNDICE I: Carta XV

5. APÊNDICE II: Cena do Lago

6. APÊNDICE III: Ilustrações de Pamela

7. APÊNDICE IV: Ilustrações de mansões inglesas da época

7. BIBLIOGRAFIA 


\section{RESUMO}

O século XVIII foi um período de grandes mudanças na estrutura social e econômica vigente. Como consequiência, a forma de organização do espaço de moradia também se alterou. Houve uma reordenação do espaço doméstico com a criação de lugares privados dentro e fora da casa e a valorização dos jardins ao redor das grandes propriedades rurais inglesas. A ascensão da nova classe média e um crescente interesse pela introspecção e privacidade propiciaram a formação destes espaços reservados ao isolamento.

A partir do surgimento do romance na primeira metade do século XVIII, o espaço doméstico viu-se valorizado e descrito com mais atenção na narrativa literária. Este cuidado em retratar a vida doméstica na literatura surgiu a partir do desejo de representar a vida dos homens comuns de modo mais autêntico. Em Pamela, romance do escritor inglês Samuel Richardson publicado pela primeira vez na Inglaterra em 1740, observamos esta ênfase no espaço interior do recolhimento e da introspecção. A relação que se estabelece entre as personagens e o espaço dentro do romance é vital para a construção do enredo.

Palavras-chave: Pamela, Samuel Richardson, espaço, romance, século XVIII. 


\begin{abstract}
Great social and economic changes were brought about in the eighteenth-century causing, among other alterations, the rearrangement of the living spaces in the houses. This reorganization of the domestic space was responsible for the creation of private spaces inside and outside the great English country houses together with an improvement in the surrounding gardens. At that time the new middle classes were gaining more and more political and economic power and developing a taste for privacy, which required the creation of specific places inside and outside the houses for the enjoyment of the pleasures of isolation and introspection.

With the rise of the novel in the first half of the eighteenth century, this domestic space was also valued, pictured and described with more attention in literature. This increasing interest in the domestic life is associated with a wish to portray the everyday lives of ordinary men with greater authenticity. In Pamela, a novel by Samuel Richardson published for the first time in England in 1740, this emphasis in the private space of isolation and introspection is clearly depicted. The deep correlation between space and characters in the novel is vital for the development of the plot.
\end{abstract}

Key-words: Pamela, Samuel Richardson, space, novel, eighteenth-century. 


\section{INTRODUÇÃO}

Este estudo pretende desenvolver uma análise da relação que se estabelece entre as personagens e o espaço no romance Pamela, do escritor inglês Samuel Richardson. No Brasil do século XXI, o interesse de um trabalho de pesquisa que verse sobre um romance da tradição literária inglesa do século XVIII pode ser justificado através das palavras de Antonio Candido, crítico que trouxe muitos avanços à teoria literária no Brasil e em cujos livros encontramos argutas análises de obras nacionais e estrangeiras, além de textos teóricos que discutem vários aspectos da literatura.

Um de seus textos que apresenta com maestria a importância da literatura na vida do homem é "O Direito à Literatura", de 1988, que se encontra no livro Vários Escritos. Neste ensaio ele faz uma reflexão sobre a necessidade do respeito aos direitos humanos para a construção de uma sociedade mais justa e inclui a literatura e a arte em geral como parte dos direitos do homem, um direito que ele qualifica como intransferível e imprescindível à sua formação.

Segundo seu entendimento, a literatura satisfaz primeiramente uma necessidade elementar e universal do homem de ficção e fantasia, pois todos indistintamente precisamos de certa dose de sonho. Além disso, a literatura é um fator de humanização, já que, ao trazer o leitor para dentro do universo literário, oferece a ele a oportunidade de viver as mais variadas experiências, proporcionando-lhe uma melhor compreensão de si mesmo e da vida. Ademais, a literatura é uma fonte de conhecimento do mundo e do ser, porque ao representar dá maior inteligibilidade à realidade social e humana. Sendo uma construção autônoma de significado, mas que não está desligada das fontes de inspiração do real, fornece um entendimento mais profundo sobre o mundo em que vivemos. ${ }^{1}$

Desta forma, mesmo sem pertencer a uma determinada sociedade localizada temporalmente distante de sua vida, o leitor, através da experiência da leitura, entra em contato com uma realidade mediada que em última instância é também sua, a sua realidade de ser vivente que experimenta na realidade particular da obra literária uma experiência que, embora não seja a sua própria, é intrínseca à vida humana.

\footnotetext{
${ }^{1}$ ANTONIO CANDIDO. "O Direito à Literatura". In: ANTONIO CANDIDO. Vários Escritos. 4ed. Rio de Janeiro:Ouro sobre Azul; São Paulo:Duas Cidades, 2004. pp. 169-191
} 
Explica-se assim o interesse de um estudo que busque compreender a estrutura de um mundo tão distante espacial e temporalmente do mundo em que vivemos. Além disso, uma pesquisa que se concentre sobre um romance do século XVIII inglês se justifica pela importância social e histórica das mudanças que viriam a alterar completamente a organização da vida no mundo ocidental nos séculos subseqüentes. Se hoje vivemos o primado do individualismo e da propriedade privada, devemos muito aos nossos antepassados que, ao difundir no século XVIII suas idéias de um direito individual acima do direito coletivo, estabeleceram as bases de um novo sistema econômico que ganharia vigor de modelo hegemônico nos séculos posteriores. Por estes e outros motivos, um estudo mais profundo sobre uma obra literária escrita na Inglaterra do século XVIII pode nos fornecer indícios sobre os motivos que nos levam a viver do modo como o fazemos hoje em dia.

Ao buscar respostas às muitas questões que se colocam a nós ao longo da vida nos valemos de muitos instrumentos, inclusive da literatura, como forma de mediação e representação da realidade. Isto nos incita a um estudo mais profundo da obra literária e dentro dela a eleger quais aspectos se destacam de forma mais viva a nosso olhar de leitor. A partir da observação de quais elementos da narrativa pareciam se sobressair dentro do romance como reveladores mais contundentes da realidade, formou-se a questão central deste estudo, que vem definida a seguir:

Qual é a relação que se estabelece entre espaço e personagem na construção do romance?

Subseqüente a esta surgiu uma segunda pergunta, decorrente da análise inicial:

Se este é um romance da interioridade e do espaço privado e doméstico, por que grande parte das ações que mudam o rumo da narrativa acontece do lado de fora da casa, nos espaços externos?

Para tanto formulamos a seguinte hipótese:

A relação que se estabelece entre os vários elementos da narrativa é uma relação de interdependência em que todos se influenciam mutuamente na construção da realidade mediada da obra literária. Deste modo, a relação entre espaço e personagem é também uma relação que ambos os elementos estabelecem entre si, portanto as personagens não encontram no espaço somente um pano de fundo sobre o qual desenrolam suas ações, mas interagem com ele de forma viva e determinante dentro da narrativa. 
Uma outra hipótese foi elaborada como possível resposta à segunda questão, referente aos espaços interno e externo:

O espaço interno, representado na narrativa pelo closet, se define no romance como o espaço da reflexão e da proteção, de domínio da mulher, e o espaço externo, como o espaço da ação e da realização, de domínio masculino. Um precisa do outro para se constituir, da mesma forma como, de acordo com a razão do século XVIII, a ação bem fundada necessita da reflexão e a reflexão precisa reverberar na ação para que haja um progresso tanto no nível pessoal quanto no social.

Partindo das questões e das hipóteses formuladas acima, o principal objetivo deste estudo é:

Elaborar uma análise da relação espaço - personagem que procure abarcar tanto o espaço interno, ou espaço da casa, quanto o espaço externo, os jardins e a área que se estende para além da propriedade.

Os conceitos que orientam esta investigação se baseiam na crítica integradora de Antonio Candido, cujas análises, segundo sua própria definição, partem de uma intuição e impressão inicial de leitor, para então se embrenhar em um trabalho de análise formal e de atenção aos fatores não literários, para com isto alcançar um juízo, uma avaliação, em que se reconhece e define o valor da obra literária. Esta somente pode ser compreendida se nos referirmos a três ordens de realidade: primeiramente, os fatores externos, que a vinculam ao tempo; em seguida, o autor, que se manifesta no texto, pois é quem o realiza formalmente; finalmente o próprio texto, que contém os elementos anteriores, mas que os transcende. ${ }^{2}$ Assim, Candido define a obra literária como

“...uma realidade autônoma, cujo valor está na fórmula que obteve para plasmar elementos não literários: impressões, paixões, idéias, fatos, acontecimentos, que são a matéria-prima do ato criador. A sua importância quase nunca é devida à circunstância de exprimir um aspecto da realidade, social ou individual, mas à maneira por que o faz."

Deste modo, esta análise também se vale dos elementos sociais, históricos, biográficos, geográficos, que se encontram no mundo extrínseco à obra, mas no qual ela está inserida, uma vez que todos os elementos que compõem a vida interagem na formação de uma única estrutura vital que organiza e é organizada por cada um de seus integrantes, os

\footnotetext{
${ }^{2}$ ANTONIO CANDIDO. Formação da Literatura Brasileira: Momentos Decisivos 1750-1880. 10ed. Rio de Janeiro, Ouro sobre Azul, 2006. p. 35.

${ }^{3}$ Id., ibid., p. 35.
} 
responsáveis pela realização dos preceitos que compõem a realidade em um determinado tempo e lugar. Um estudo literário que não visse a obra como parte integrante de seu tempo deixaria de levar em conta importantes dados, que enriquecem e aclaram a análise, e certamente perderia na compreensão mais profunda da cosmovisão do autor, que, com sua técnica e genialidade, formaliza na literatura os movimentos históricos e sociais de uma determinada sociedade a um determinado tempo, pois como nos diz Antonio Candido, "...a realidade social se transforma em componente de uma estrutura literária [...] e só o conhecimento desta estrutura permite compreender a função que a obra exerce."4

Finalmente, gostaríamos de salientar que há muitos estudos sobre este romance publicados em outros países, porém, à exceção de alguns literatos que se debruçaram com afinco e entusiasmo sobre a literatura inglesa deste período, poucos são os trabalhos de pesquisa produzidos no Brasil sobre as obras do século XVIII inglês, e mais especificamente sobre Pamela. Do mesmo modo, há muitas análises que centram seu olhar sobre outros elementos que compõem a narrativa que não o espaço, ou que, ao observá-lo no romance, se concentram no espaço interior, doméstico, com poucas referências ao ambiente externo e às ações que se desenrolam do lado de fora da casa. Assim sendo, este estudo procura abranger estes dois aspectos: os espaços interno e externo, descrevê-los e analisá-los em sua relação com as personagens. Este é o foco último deste estudo, que, embora se concentre sobre a constituição do espaço no romance, não pode deixar de se referir a outros elementos essenciais de sua composição, como personagem, narrador e modo narrativo, uma vez que o leitor está submetido a uma narradora que é também a protagonista de sua própria história, e que a transmite ao leitor através da escrita de cartas e de um diário, ação que realiza no espaço privado de seu closet. Esta análise, portanto, procura abranger não somente o espaço, mas estudar a relação que este estabelece com outros elementos da narrativa, uma vez que todos agem juntos no processo de realização da obra literária.

Seja para saciar uma necessidade de fantasia, seja como forma de conhecimento do mundo ou apenas pelo prazer de seu valor estético, a literatura matiza o ser com seu colorido vibrante, e sua apreciação tanto como leitor quanto como estudioso permite ao homem a possibilidade de desfrutar de um estilo de vida que contemple “...o belo natural, o belo artístico, o belo pensar",

\footnotetext{
${ }^{4}$ ANTONIO CANDIDO. Literatura e Sociedade. 9ed. Rio de Janeiro, Ouro sobre Azul, 2006. p. 9.

${ }^{5}$ PERNIOLA, M. "Expansão e fragmentação do horizonte estético". Revista Diacrítica: Filosofia e Cultura. Universidade do Minho, n. 20/2, 2006. p. 108.
} 


\section{PAMELA:}

\section{A RELAÇÃO PERSONAGEM / ESPAÇO NO ROMANCE}

Virginia Woolf, em A Room of One's Own, defende a idéia de que para se tornar escritora a mulher necessita de independência financeira e privacidade, condições que ela considera vitais ao desenvolvimento da escrita de ficção. Seu inteligente e sagaz ensaio tem como foco a situação feminina em comparação e contraste com a posição do homem na sociedade ao longo dos tempos, e parte de sua própria experiência, pois, como escritora no início do século XX, Woolf circulava em rodas substancialmente masculinas. Sua observação e vivência motivaram uma profunda pesquisa que toca pontos como a segurança e prosperidade naturalmente conferidas ao homem em contraste com a pobreza e insegurança usualmente presentes na vida da mulher. ${ }^{6}$

Após detalhado estudo, ela conclui que os textos antigos sobre o universo feminino eram invariavelmente escritos a partir de uma perspectiva masculina e que pouco se sabe de fato sobre a vida das mulheres anteriormente ao século XVIII. No entanto, uma grande mudança sobreveio neste período, pois

"...towards the end of the eighteenth century a change came about which, if I were rewriting history, I should describe more fully and think of greater importance than the Crusades or the Wars of the Roses. The middle-class woman began to write."7

Aos poucos estas mulheres começaram a escrever e descrever suas vidas, seus desejos, suas aflições, suas dúvidas, fruto da observação do caráter e da análise das emoções a que elas estavam habituadas após tantos anos de confinamento no âmbito do espaço doméstico. Talvez por isso o romance fosse uma forma mais apropriada, pois "If one shuts one's eyes and thinks of the novel as a whole, it would seem to be a creation owing a certain looking-glass likeness to life, though of course with simplifications and distortions innumerable." $\mathrm{O}$ escritor seria então aquele ser que vive mais intensamente a realidade da vida, pois a ele é conferida a tarefa de encontrá-la, coletá-la e comunicá-la ao resto do mundo. ${ }^{9}$

\footnotetext{
${ }^{6}$ WOOLF. V. A Room of One's Own. London, Penguin, 2004. p. 28.

${ }^{7}$ Id., ibid., p. 75.

${ }^{8}$ Id., ibid., p. 82.

${ }^{9}$ Id., ibid., p. 127.
} 
Mesmo receando parecer demasiado materialista, Woolf reafirma ao final de seu ensaio a importância do capital e do espaço privado para a criação, pois segundo ela "Intellectual freedom depends upon material things. Poetry depends upon intellectual freedom. And women have always been poor, not for two hundred years merely but from the beginning of time."10

Em uma clara referência ao ensaio de Woolf, Robert Folkenflik, em A Room of Pamela's Own, parte da questão da privacidade para analisar o espaço no romance Pamela de Samuel Richardson, objeto deste estudo. Enquanto Woolf utiliza a questão espacial para defender a independência da mulher como necessidade básica para o desenvolvimento completo de suas capacidades, Folkenflik afirma que, em Pamela, o espaço privado não está associado à liberação feminina, como não poderia ser no início do século XVIII, mas sim à autodeterminação da mulher $^{11}$, ou seja, à compreensão de si mesma como indivíduo pertencente a um determinado extrato social a partir do qual se estabelecem as relações interpessoais no romance.

A corte de um jovem aristocrata à bela criada é o conflito que centra a ação deste romance, publicado no século XVIII e que é parte da tradição literária inglesa. Do início ao final da narrativa o leitor é conduzido através do desenrolar do relacionamento amoroso entre Pamela e Mr B.: ela é a dama de companhia com atributos muito além de sua condição social; ele, o típico representante das classes mais abastadas: voluntarioso, libertino e inconseqüente. Esta fábula romântica, cujo enredo é construído a partir de cartas da criada a seus pais e posteriormente de um diário que a jovem escreve durante o período que passa isolada e incomunicável na mansão de Lincolnshire, pode de início dar a impressão de uma história rasa, mas de fato revela uma grande profundidade de sentido e uma vasta agudeza de compreensão.

A julgar pela popularidade da obra na época (sua primeira publicação data de 1740) podemos dizer que seu alcance e influência foram muito maiores do que podemos imaginar nos dias de hoje. R. F. Brissenden diz sobre Pamela, "There has perhaps never been a literary success quite like that of Pamela. Certainly no previous work of fiction had ever attained such rapid, widespread and enduring popularity, and few have since." 12 Esta afirmação de 1965 pode nos parecer exagerada nos dias de hoje, uma vez que nos séculos subseqüentes à publicação de Pamela o mundo editorial conheceu uma expansão sem precedente. Contudo,

\footnotetext{
${ }^{10}$ Id.,ibib., p. 123.

${ }^{11}$ FOLKENFLIK, R. “A Room of Pamela's Own”. ELH. Johns Hopkins University, v.39, n.4, dez. 1972. p. 585.

${ }^{12}$ BRISSENDEN, R. F. Samuel Richardson. London, Longmans Green, 1965. p. 11.
} 
tal expressão nos dá uma dimensão da importância da obra na época e de sua relevância para a evolução do gênero na tradição literária inglesa. De 1740 a 1762, o romance teve oito edições autorizadas, sendo uma dessas ricamente ilustrada por dois renomados artistas da época, Hubert François Gravelot e Francis Hayman. O propósito das ilustrações era, em parte, elevar a personagem de Pamela, portanto Richardson escolheu cenas que mostrassem a dignidade e o refinamento da jovem, que é retratada nas estampas mais como uma dama do que propriamente como uma criada. Além de figurar nas ilustrações que fazem parte da obra, Pamela também serviu de inspiração para trabalhos em cera, pinturas em leques, murais e telas $^{13}$, o que comprova o grande apelo do romance e de sua protagonista. Com o passar dos anos, no entanto, a reputação de Richardson e a popularidade de sua obra declinaram. De fato acredita-se que, no final do século XVIII e início do século XIX, sua popularidade se restringisse ao público infantil. ${ }^{14}$ Esta idéia parece ser comprovada pelo romance Jane Eyre de Charlotte Brontë, publicado na Inglaterra em 1847. Nas primeiras páginas do livro, a personagem conta os anos de sua infância passados na casa dos tios. Sua memória a reporta às frias noites de inverno em que Bessie, a ama, contava histórias de amor e aventura às crianças extraídas de antigas baladas, contos de fadas ou “...(as at a later period I discovered) from the pages of Pamela..."15

Hoje em dia, as urgências da vida moderna dificultam a leitura de uma história como a de Pamela e colocam em segundo plano a personagem que, há um tempo, foi “...the heroine of ladies, gentlemen, and chambermaids..." $\mathrm{Na}$ visão de Brissenden isso se deve principalmente à prolixidade de Richardson, já que seus romances são longos, e à dificuldade de leitura colocada pela forma epistolar, que parece artificial ao leitor moderno. Contudo, a importância do romance na literatura do século XVIII é inegável. Em seu livro The Rise of the Novel, Ian Watt destaca três escritores da primeira metade do século XVIII que seriam responsáveis pela criação do romance moderno. São eles: Daniel Defoe, Samuel Richardson e Henry Fielding, que com seus romances teriam estruturado as bases de um novo gênero literário.

13 Joseph Highmore produziu, entre os anos de 1742 e 1745 , uma série de 12 telas que narram o enredo do romance. Estas telas, embora pintadas sem o conhecimento de Richardson, foram apreciadas pelo autor por preservar o espírito do romance e ilustrar de modo fiel as personagens, a arquitetura e os costumes da época. Hoje elas podem ser vistas em alguns dos museus da Inglaterra, como a National Gallery ou a Tate Gallery de Londres. Nas palavras de Duncan Eaves estes quadros são “....without doubt, the greatest illustrations ever made for the novel." DUNCAN EAVES, T. C. "Graphic Illustration of the Novels of Samuel Richardson: 1740-1810". The Huntington Library Quarterly. University of California, v.14, n.4, ago. 1951. p. 358.

14 DUNCAN EAVES, T. C. "Graphic Illustration of the Novels of Samuel Richardson: 1740-1810". The Huntington Library Quarterly. University of California, v.14, n.4, ago. 1951. p. 382.

${ }^{15}$ BRONTË, C. Jane Eyre. London, Penguin, 1994. p. 11.

${ }^{16}$ DUNCAN EAVES, 1951, p. 362. 
O estudo de Ian Watt parte da tentativa de responder a uma pergunta que para ele se apresenta como crucial para o entendimento do gênero. Ele dá início à sua análise se questionando se estes romancistas estariam realmente produzindo uma nova forma de literatura e, ao assumir que a resposta é afirmativa, de que maneira ela se diferencia da prosa de ficção anterior. A resposta parece estar naquilo que ele define como 'realismo formal'. Ao falar em realismo ou gênero 'realista', Watt não pretende exprimir a idéia de que toda a literatura anterior ao surgimento do romance buscasse retratar o irreal, mas sim que a forma usada pelo romance para imitar a realidade busca, através de uma série de procedimentos formais, transmitir "...an authentic account of the actual experience of individuals." ${ }^{17}$ Para ele, o romance se diferencia da narrativa em prosa produzida até então, por tratar da história de um homem comum que narra sua experiência individual de vida. $O$ herói do romance não é um homem que representa os desejos ou aspirações de sua coletividade. Ele é um homem comum, com uma vida comum, problemas e desafios comuns a cada um de nós; e é justamente por retratar cenas da vida que o romance atinge seu objetivo de compartilhar a experiência de um na tentativa de abranger o todo.

O romance surge a partir de uma drástica mudança filosófica que se inicia com Locke e Descartes no século XVII e que tem por princípio a negação da teoria medieval de que as verdadeiras 'realidades' seriam universais, e defende o princípio de que a verdade somente pode ser descoberta através da experiência individual de cada ser humano que apreende este mundo real através de seus sentidos ${ }^{18}$. Sendo assim, a partir do Renascimento a crença na experiência individual do homem em detrimento da tradição coletiva propicia o surgimento de um gênero literário que viesse ao encontro dessa nova visão de mundo.

Através de uma série de procedimentos formais, o romance busca a autenticidade dos fatos que relata. Para Watt, as características que fariam do romance "....a full and authentic report of human experience" 19 seriam mais precisamente um enredo a serviço do relato de uma vida comum, de uma experiência individual única; a particularização da personagem, que é apresentada como uma pessoa comum, com um nome comum e não raro um sobrenome; a particularização do tempo que influencia as personagens, mudando sua maneira de pensar e agir através da experiência pessoal que se desenvolve ao longo do tempo; a particularização do espaço que é específico e claramente definido na narrativa; e

\footnotetext{
${ }^{17}$ WATT, I. The Rise of the Novel: Studies in Defoe, Richardson and Fielding. London, Pimlico, 2000. p. 27.

${ }^{18}$ Id., ibid., pp. 11-12.

${ }^{19}$ Id., ibid., p. 32.
} 
finalmente, a linguagem usada pelos romancistas é clara e simples e procura reproduzir a linguagem dos homens comuns.

Dentro desta perspectiva, isto que Watt define como 'realismo formal' seria então uma série de procedimentos formais, dentro da convenção literária, que são mais comumente encontrados no romance do que em outros gêneros narrativos, e que através de seu uso buscam relatar de forma autêntica, um ou mais aspectos da experiência humana de vida.

Ainda segundo Watt, a grande contribuição de Richardson para o desenvolvimento do novo gênero teria sido a idéia de evitar um enredo episódico e centrar seu romance em uma única ação: a corte de Mr B. a Pamela. Tudo no romance está a serviço do relato desse envolvimento amoroso entre as personagens e os posteriores desdobramentos desta conquista.

Dentre os elementos que compõem o 'realismo formal' a que se refere Watt, está a caracterização do espaço, objeto deste estudo. Assim sendo, iniciaremos com uma descrição dos aspectos gerais deste que é um dos elementos fundamentais do gênero.

O espaço em que se desenvolve a narrativa é o das típicas mansões inglesas do século XVIII e sua função, que em princípio parece ser apenas a de ambientar as ações das personagens, é central ao enredo. As duas mansões em que a trama se desenrola localizam-se nos condados de Bedfordshire e Lincolnshire, respectivamente, e possuem muitas características em comum, como os inúmeros quartos e salas, uma extensa biblioteca, dependências de empregados, e imensos jardins com vastos gramados, lagos e recantos privativos. Sua localização as coloca a uma distância de cerca de um dia e meio de viagem em carruagem, como fica claro nesta passagem ao final do romance, em que as personagens partem de Lincolnshire em direção a Bedfordshire:

\section{"SATURDAY}

On Thursday morning Lady Davers (...) set out for her own seat; and my best friend and I (...) for this dear house. (...)We arrived not here [Bedfordshire].till yesterday noon." 20

${ }^{20}$ RICHARDSON, S. Pamela, or Virtue Rewarded. London, Penguin, 1985. p. 477. 


\subsection{A caracterização do espaço: a mansão de Bedfordshire}

A narrativa tem início na mansão de Bedfordshire, a residência principal da família Brandon. Os acontecimentos permanecem vinculados a este espaço por cerca de oitenta páginas, que correspondem na história a um período de pouco mais de um ano. Após este período inicial a narrativa é transferida para a mansão de Lincolnshire, para onde Pamela é levada ao ser raptada por Mr B. A viagem de carruagem que a transporta de um espaço a outro ocupa mais de vinte páginas do romance. A chegada e posterior estabelecimento nesta segunda casa tomam grande parte do romance e é neste ambiente que se dá a reforma social e moral das personagens. A narrativa neste novo espaço ocupa cerca de trezentas páginas, que temporalmente corresponde a um período de aproximadamente três meses. Ao final, o leitor é levado novamente ao espaço inicial da mansão de Bedfordshire, através de uma nova viagem que toma cerca de três parágrafos da narrativa, para seguir-se o estabelecimento na imponente mansão do início do romance. A chegada e as considerações finais ocupam as últimas quarenta páginas do romance e relatam os acontecimentos das duas primeiras semanas da nova vida das personagens.

A mansão de Bedfordshire se localiza a duas milhas e meia da cidade mais próxima e a uma considerável distância de Londres, segundo as palavras do próprio $\mathrm{Mr} \mathrm{B}$. em conversa com o pai de Pamela, quando este vai procurá-lo para inquirir sobre o desaparecimento da filha:

“'Why, London is a great way off,' said Mr. B. 'and I can't send for her back
presently., 21

De acordo com o pai de Pamela, a mansão é uma "great house"22. As ilustrações produzidas por Hayman e Gravelot nos mostram uma grandiosa vila italiana ricamente decorada no melhor estilo neoclássico. Seus jardins são imensos, com terraços, caminhos e estátuas, ao modo dos jardins 'artificiais' italianos, e possuem vários recantos, como o jardim privativo com sua summer-house. Neste ambiente se desenrola um dos acontecimentos mais marcantes da história, responsável pela alteração do curso da narrativa e que revela à personagem a verdadeira intenção de Mr B. Referimo-nos à cena em que este vai ao encontro de Pamela na summer-house e onde se dá a primeira demonstração explícita de seu interesse

\footnotetext{
${ }^{21}$ Pamela, carta XXXI, p. 127.

${ }^{22}$ Pamela, carta XIII, p. 59.
} 
pela jovem. Pouco se sabe sobre esta summer-house, além de que ela se localiza em um pequeno recanto do jardim

"And one day he came to me, as I was in the summer-house in the little garden..."23

e que é mobiliada com bancos e separada do exterior por uma porta, o que faz dela um ambiente fechado e, portanto, reservado, porém localizado na parte externa da casa, em espaço aberto. Nesta cena, Pamela bordava quando Mr B. vai a seu encontro e após a conversa entre os dois a jovem diz:

"I took a turn or two in the garden, but in sight of the house, for fear of the worst;", 4

Tal frase nos dá uma dimensão dos jardins da mansão e corrobora sua importância na caracterização das residências da aristocracia inglesa.

Ainda na parte externa da casa localizam-se o estábulo e as dependências dos empregados. Para se alcançar os jardins ou o interior da casa é preciso cruzar um portão, como se pode notar na passagem em que o pai de Pamela vai à sua procura na casa de Mr B. Após viajar durante toda a noite, Mr Andrews

“...found himself soon after daylight at Mr B.'s gate, before the family was up; and there he sat down to rest himself, till he should see somebody stirring." 25

Pouco mais se sabe sobre o jardim além do fato de que o quarto de $\mathrm{Mr}$ B. abre para um jardim privativo, como veremos logo mais.

Quanto à casa propriamente dita, podemos inferir a localização dos cômodos através do uso das palavras up e down no texto. Sabemos que no andar inferior localizam-se o hall, o lobby, várias salas, como o housekeeper's parlour, o steward's room, um back-parlour, a sala de jantar e a cozinha.

O quarto de $\mathrm{Mr}$ B. com sua biblioteca também se localiza no andar inferior da casa e merece uma das poucas, porém sucintas, descrições espaciais no romance. Mr B. deseja falar com Pamela e a chama a seus aposentos. Esta vai cheia de temores, decidida a pedir-lhe perdão pela liberdade que tomou com ele no dia anterior. Ele pede que ela o acompanhe a seu closet e feche a porta. Ao ver Pamela relutante em fazê-lo, Mr B. insiste:

\footnotetext{
${ }^{23}$ Pamela, carta XI, p. 54.

${ }^{24}$ Pamela, carta XI, p. 56.

${ }^{25}$ Pamela, carta XXXI, p. 126.
} 
“ 'By the G - d that made me,' said he, 'I'll do you no harm. Shut the parlour-door, and come to me in my library.' He then went into his closet, which is his library, and full of rich pictures besides; a noble apartment, though called a closet, and next the private garden, into which it has a door that opens."26

Esta brevíssima descrição dos aposentos de Mr B. deixa clara sua localização no andar inferior da casa, pois sua biblioteca abre para um jardim privativo.

Há também outros cômodos no andar inferior como, por exemplo, um cômodo a que Pamela se refere como green-room. Este aposento também é brevemente descrito, pois é cenário de mais uma das inúmeras armadilhas de $\mathrm{Mr} \mathrm{B}$, que se esconde ali para ouvir a conversa da criada com Mrs Jervis.

“" 'Let your things,' said she, 'be brought down into the green-room, and I will do any thing you would have me do.' (...) Now in this green-room is a closet, with a sash-door and a curtain before it; for there she puts her sweet-meats and such things; and into this closet my master had got unknown to me;"27

Já o quarto da senhora de Pamela localiza-se no andar superior, pois segundo a própria Pamela:

"He [Mr B.] called me up to my late lady's closet..."28.

Ainda no andar superior está o quarto da governanta, como podemos inferir a partir da seguinte frase de Pamela:

"She [Mrs Jervis] was so good as to indulge me; but made haste to come up to bed; and told the female servants, that I should lie with her, because she could not rest well...",29

O quarto de Pamela também parece se localizar neste andar, pois, depois do desapontamento de seu encontro com Mr B. no jardim, Pamela diz ter passado o dia

"In this perplexity; now considering, now crying, and not knowing what to do, I passed the time in my chamber till evening; when desiring to be excused going to supper, Mrs Jervis came up to me,...,

\footnotetext{
${ }^{26}$ Pamela, carta XXX, pp. 114-115.

${ }^{27}$ Pamela, carta XXIX, p. 110.

${ }^{28}$ Pamela, carta VII, p. 50.

${ }^{29}$ Pamela, carta XII, p. 57.

${ }^{30}$ Pamela, carta XII, p. 57.
} 
As dependências das criadas ficam no interior da casa, porém, sendo mínimas as referências a elas, não se pode concluir ao certo sua localização. Parecem estar em um andar acima ao do quarto da governanta, como se pode inferir a partir das palavras de $\mathrm{Mr} \mathrm{B}$. no episódio em que este é descoberto escondido no closet de Mrs Jervis.

"I screamed, and ran to the bed; and Mrs Jervis screamed too; and he said, 'I'll do you no harm, if you forbear this noise; but otherwise take the consequences.' Instantly he came to the bed-side (for I had crept into it, to Mrs Jervis, with my coat on, and my shoes); and, taking me in his arms, said, 'Mrs Jervis, rise, and just step up stairs, to keep the maids from coming down at this noise: I'll do no harm to this rebel." ",31

As passagens apresentadas nos mostram que a escassez de descrições espaciais dificulta a compreensão da localização dos cômodos da casa. No entanto, o entendimento de como se dá a distribuição destes cômodos na residência e de seus respectivos usos pode ser extraído do próprio texto.

Antes de iniciarmos uma exposição mais detalhada das relações que se estabelecem nestes espaços, é importante considerarmos o conceito de espaço. O espaço não pode ser entendido como algo palpável, pois não é material. Ele contém e é contido pela matéria, mas não é visível: o que se pode ver e observar é a matéria que o delimita. Sob este ponto de vista torna-se mais difícil compreendê-lo, pois ele está além dos elementos materiais que o determinam e definem.

Podemos falar em espaço quando nos referimos ao interior de um bule, por exemplo, ou quando nos referimos ao espaço sideral. No entanto, o que nos interessa neste estudo é o espaço humano ou social: aquele em que se desenrolam as relações entre os homens. Milton Santos o define como: "a morada do homem, é o seu lugar de vida e de trabalho" 32 .

Ao assumirmos que o espaço não é vazio, e que o espaço humano somente se constitui como tal a partir de seu uso ou da intenção de uso, ele somente pode ser compreendido através da ligação entre os homens e as atividades que nele se realizam. Para Milton Santos, o espaço é “...um conjunto de relações realizadas através de funções e de formas que se apresentam como testemunho de uma história escrita por processos do passado e do presente. Isto é, o espaço se define como um conjunto de formas representativas de relações sociais do passado e do presente e por uma estrutura representada por relações

\footnotetext{
${ }^{31}$ Pamela, carta XXV, p. 95.

${ }^{32}$ SANTOS, M. Por uma Geografia Nova: da Crítica da Geografia a uma Geografia Crítica. 2ed. São Paulo, Hucitec, 1980. p. 120.
} 
sociais que estão acontecendo diante dos nossos olhos e que se manifestam através de processos e funções." 33

Segundo este entendimento, o espaço não pode ser compreendido isoladamente, mas somente através da interdependência que se estabelece entre ele, os homens que o ocupam e as ações que estes executam dentro de seus limites.

\subsection{A ênfase no espaço interior}

Nesta primeira mansão observamos uma ênfase no espaço interior, pois grande parte da narrativa acontece nas dependências internas da casa, onde se dão os encontros entre Pamela e Mr B., e entre estes e as demais personagens.

Em seu estudo sobre a representação do espaço no romance Clarissa, de Samuel Richardson, Karen Lipsedge afirma que a partir do século XVIII começou-se a dar maior atenção ao espaço doméstico das personagens, não mais o caracterizando na forma de lugares desprovidos de valor, com a única função de oferecer um suporte arquitetônico à ação, mas apresentando-o como espaços definidos, com uma função específica e um estilo decorativo próprio, fazendo deste elemento da narrativa algo tão tangível quanto as próprias personagens que o ocupam. Segundo ela, esta mudança se deve a uma alteração no método narrativo, uma vez que os tipos humanos gerais localizados em tempo e espaço indefinidos, que inundavam a prosa de ficção anterior ao romance, foram substituídos por personagens mais realistas que passaram a habitar ambientes específicos.

Ao buscar na história uma explicação para esta mudança literária, Lipsedge conclui que a reestruturação do espaço doméstico se deu graças aos novos aspectos culturais e sociais que ganharam força no início do século XVIII. A afluência da classe média e o aumento do tempo ocioso permitiram a criação do hábito da visitação entre conhecidos e vizinhos, o que transformou a casa em um espaço de sociabilidade. A acessibilidade ao interior da casa por um número maior de visitantes trouxe como conseqüência um maior cuidado com sua construção e decoração, pois o ambiente doméstico passou a ser um indício do gosto e caráter de seu proprietário e de sua riqueza e posição social. Semelhantemente, a facilidade de acesso de estranhos ao espaço de moradia suscitou também a necessidade da criação de ambientes reservados dentro da casa que permitissem o isolamento e a privacidade. Este isolamento, no

\footnotetext{
${ }^{33}$ Id., ibid., p. 122.
} 
entanto, não era somente desejado como uma forma de afastamento do convívio social, mas era também uma necessidade gerada por uma crescente consciência da vida interior de cada um, do indivíduo que passava a se compreender não mais a partir da coletividade, mas de sua própria experiência do mundo. Este indivíduo com experiências únicas de vida desejava desfrutar de momentos de total isolamento dedicados a atividades solitárias e pessoais como a leitura silenciosa, a escrita, a meditação e a introspecção.

Esta nova percepção do espaço doméstico estendeu-se ao jardim, já que o espaço externo à casa também se constituía como um espaço de visitação e se caracterizava como forma de demonstração do caráter, da riqueza e do bom gosto de seu proprietário. ${ }^{34}$ Assim sendo, as visitas eram recebidas não somente no interior das casas, nos elegantes parlours, mas também nos inúmeros recantos e construções do jardim, como a great alcove em que $\mathrm{Mr}$ B. recebe seus convidados em Lincolnshire, quando apresenta Pamela aos seus vizinhos. Da mesma forma, além dos espaços de sociabilidade, o jardim deveria proporcionar a seus usuários espaços privativos, recantos isolados e tranqüilos apropriados aos momentos de introspecção. Nesta primeira mansão podemos observar a presença de alguns destes espaços privados localizados no jardim. Como já dissemos anteriormente, a summer-house localizava-se em um little garden. Além disso, a narrativa nos informa que Mr B. possui um jardim privativo contíguo ao quarto de dormir. Embora saibamos da existência deste jardim somente por uma referência no texto e seu uso não seja apresentado no romance, a necessidade de um espaço de isolamento ao ar livre está claramente caracterizada.

Se para Lipsedge a nova constituição dos espaços internos e externos da casa se deve à prática social do hábito da visitação, Nancy Armstrong defende a teoria de que a ênfase no espaço doméstico na prosa de ficção do século XVIII se deve a razões políticas. Para ela, a classe média emergente teria sido responsável por consolidar através da literatura um novo modo de organização da vida baseado na reconstituição do conceito de feminino e da posição social da mulher. A criação da noção da domestic woman ${ }^{35}$ estabelecia o domínio da mulher sobre todas as práticas associadas à vida privada, provocando uma redefinição da ocupação e do uso dos espaços dentro e fora da casa. A vida familiar e doméstica, previamente governada pelo homem, passou às mãos da mulher e estabeleceu-se uma divisão do mundo

\footnotetext{
${ }^{34}$ LIPSEDGE, K. "A Place of Refuge, Seduction or Danger? The Representation of the Ivy Summer-House in Samuel Richardson's Clarissa”. Journal of Design History. Oxford University, v.19, n.3, ago. 2006. pp. 185186.

35 ARMSTRONG, N. Desire and Domestic Fiction: a Political History of the Novel. New York, Oxford University, 1987. p. 3.
} 
em dois grandes espaços: o espaço doméstico de domínio feminino e o marketplace de domínio masculino ${ }^{36}$.

Em consequiência a esta nova concepção das funções familiares da mulher, redefiniram-se também os atributos que ela deveria desenvolver para se qualificar como boa mãe e boa esposa. Deste modo, esta prosa de ficção, a que Armstrong se refere como domestic fiction, passou a apresentar na figura da heroína uma mulher cujo valor se definia mais por suas qualidades mentais do que por suas qualidades estéticas. A mulher burguesa, por sua profundidade psicológica, valor moral e uma incansável preocupação pelo bem-estar dos outros, caracterizava-se como superior e, portanto, mais desejável ao homem do que uma aristocrata de aparência sensual e atraente, mas psicologicamente superficial e fútil que levava ao casamento somente um título e o status social de sua classe. Ao se referir ao romance de Richardson, Armstrong diz:

"To be sure, Pamela carried on the [...] struggle to define the female that was being waged wherever writing invoked the need for female education and for the reform of sexual practices. Represented as the struggle between a master and his female servant, Pamela contained this struggle first within the household and then within the writing that transformed Pamela herself into a distinctively female form of subjectivity. The differentiation and enclosure of a female self was nothing short of a victory for the modern self over the political system that was authorized by a household which a male governed and sustained by his patronage." 37

Richardson teria sido, desta forma, o precursor da tradição da ficção doméstica colocando em evidência uma mulher que era a personificação da virtude, do sentimento, das emoções e da moral ilibada. Em seu livro Dez Lições sobre o Romance Inglês do Século $X V I I I$, Vasconcelos afirma que a personagem richardsoniana

“...é concebida em função de suas qualidades mentais essenciais e das nuances mais sutis de comportamento e não mais em termos do sistema de status dominante no pensamento britânico, segundo o qual o valor de cada um era definido em função de seus títulos e origem." 38

Para ela, este novo ideal de mulher, a mulher doméstica, sensível e virtuosa, professado no romance, constituía parte do movimento de consolidação dos novos ideais burgueses. Em conseqüência da ascensão deste novo conceito de mulher, representado na figura da heroína, o espaço interno da casa passou a abrigar a ação das personagens e se

\footnotetext{
${ }^{36}$ Id., ibid., pp. 9-10.

${ }^{37}$ Id., ibid., p. 118.

${ }^{38}$ VASCONCELOS, S. Dez Lições sobre o Romance Inglês do Século XVIII. São Paulo, Boitempo, 2002. p. 73.
} 
configurou "...como lugar privilegiado do exercício da individualidade e da subjetividade"39, trazendo a narrativa para dentro da vida doméstica e dos espaços privados da casa.

De acordo com tudo o que foi dito previamente, o romance abre com o relato da morte da senhora de Pamela, descrito na carta que a jovem escreve aos pais "in her late lady's dressing room" 40 . Esta é de fato a primeira referência a este que será um dos espaços mais utilizados pela criada na mansão de Bedfordshire. Embora várias cenas se desenrolem em diferentes espaços internos e externos, este é o lugar que Pamela usa para escrever suas cartas e dar vazão aos seus sentimentos mais íntimos. Estamos falando aqui do closet das mansões inglesas do século XVIII.

O closet era um espaço privado que se prestava ao recolhimento e à introspecção necessários à leitura ou à correspondência. Nas notas que fazem parte da edição da Penguin Classics, o closet é descrito como "a small room of privacy and retirement" ", mobiliado com escrivaninhas, estantes, cômodas, sofás ou poltronas, contíguo ao quarto de dormir, mas em geral separado deste por uma passagem ou porta.

A narrativa não permite que compreendamos exatamente o uso do closet, pois para Mr B. seu closet é sua biblioteca. O closet da senhora era seu dressing-room. E na mansão de Lincolnshire, o quarto de Pamela tem dois closets. O que se sabe, no entanto, é que este é um espaço privativo, utilizado para a realização de atividades solitárias, como a leitura e a escrita, e dedicado aos momentos de estudo ou de introspecção.

Neste contexto, o espaço privado tem a função de oferecer à personagem momentos propícios à reflexão e à ordenação dos acontecimentos. Através do isolamento em seu closet, Pamela busca proteção e distanciamento dos fatos que exacerbam sua emoção na tentativa de reordená-los intimamente. A ênfase neste espaço íntimo está ligada à escolha, por parte do autor, de uma narrativa epistolar. É graças a ela que o closet assume sua função essencial dentro da narrativa, pois é através da atividade da escrita, realizada por Pamela neste espaço, que os fatos da história alcançam o leitor.

Para Pamela, no entanto, esta não é sua única função. O closet é o espaço em que ela se refugia não só para escrever suas cartas ou seu diário, mas também para chorar suas mágoas ou dar graças por suas alegrias, como se pode notar nas frases a seguir, apenas algumas das inúmeras encontradas ao longo de todo o romance:

\footnotetext{
${ }^{39}$ Id., ibid., p. 81.

${ }^{40}$ Pamela, carta I, p. 44.

${ }^{41}$ Pamela, notas do editor, p. 518.
} 
"I left them together, and retired to my closet, to write a letter..."42

"And threw myself upon the couch in my closet, and wept bitterly." 43

“....and saluting me there again, left me to go up to my closet, where I threw myself on my knees, and blessed that gracious God, who had thus changed my distress to happiness, and so abundantly rewarded me for all the sufferings I had passed through." 44

Como já dissemos anteriormente, uma das mudanças introduzidas pelo novo gênero no século XVIII foi uma caracterização mais refinada da localização espacial das ações e das personagens dentro do enredo. Se entendemos o romance como um relato biográfico, a representação da vida de um indivíduo em uma sociedade e um tempo determinados, esta ênfase dada ao espaço doméstico e à vida privada nos parecerá mais lógica se buscamos uma explicação para tais mudanças na história social.

No mundo feudal da Idade Média, em que os acontecimentos da vida ainda obedeciam a um ritmo natural e que ainda se podia referir a ela como sendo de certa maneira una e orgânica, as esferas do público e do privado se confundiam, pois muitos dos atos da vida cotidiana se realizavam em público. A pequena comunidade limitava o indivíduo, pois todos nela se conheciam, e as casa eram habitadas por um grande número de pessoas, por isso os espaços privados se encontravam principalmente do lado de fora da casa, nos campos, nos pomares, nas florestas. Ao chegarmos ao século XIX, a situação já se encontrava diferente, pois a população anônima das cidades trouxe o homem para dentro do convívio familiar.

A passagem de um modo de vida a outro se deu graças a um grande número de mudanças que alteraram a concepção de indivíduo e de seu papel na sociedade. Três fatores, surgidos a partir do século XVII, contribuíram grandemente para essa mudança. Primeiramente, o novo papel do Estado, que passou a interferir mais fortemente sobre as condições de vida do indivíduo, seu papel na sociedade e o espaço social. Em seguida, o desenvolvimento da alfabetização e a difusão da leitura. Aqui se deve ressaltar a difusão da leitura silenciosa, ato que permite a reflexão solitária. Além desses aspectos, deve-se também acrescentar as novas formas de religião estabelecidas nos séculos XVI e XVII que davam maior ênfase à devoção interior e ao relacionamento pessoal e individual com Deus.

\footnotetext{
42 Pamela, diário, p. 196.

${ }^{43}$ Pamela, diário, p. 202.

${ }^{44}$ Pamela, diário, pp. 311-312.
} 
A realidade cotidiana também sofreu grandes mudanças em sua organização. $O$ individualismo trouxe a conquista da intimidade associada a espaços no interior da casa dedicados às confidências e aos segredos. Posteriormente, grupos de convívio para conversação e leitura surgiram como forma de divertimento para os membros das classes intermediárias que procuravam evitar tanto a solidão quanto a multidão. Finalmente, a família passou a ser considerada lugar de refúgio e de afetividade, recolhendo e defendendo o indivíduo e tornando-se uma célula, separada da sociabilidade anônima da rua.

Pode-se dizer, portanto, que a grande questão da história da vida privada está centrada na sociabilidade, ou seja, na "substituição de uma sociabilidade anônima - da rua, do pátio do castelo, da praça, da comunidade - por uma sociabilidade restrita que se confunde com a família, ou ainda com o próprio indivíduo" ${ }^{\text {" }}$. Em outras palavras, observamos a passagem de uma sociabilidade em que o público e o privado se confundiam para uma nova forma de sociabilidade em que o privado estava separado do público.

Há ainda outro significado que pode ser aplicado aos conceitos de público e privado, segundo Ariés. "Nesta concepção, o público é o Estado, o serviço do Estado, e o privado - ou melhor, como se dizia sem nenhuma ambigüidade, o 'particular' - referia-se a tudo que escapasse ao Estado. ${ }^{\circ 6}$ Deste modo, como na Idade Média o Estado era fraco, a vida das pessoas dependia da solidariedade e da coletividade. Aqui público e privado se confundiam. Com o surgimento de um Estado mais forte e o estabelecimento das leis e da ordem, as condições básicas de sobrevivência passaram a ser fornecidas pelo Estado, deixando, a vida dos indivíduos, de depender da coletividade. Nesta nova forma de vida, que passou a vigorar principalmente a partir do século XVII, as esferas do público e do privado se separaram e o espaço privado pôde se organizar como um espaço fechado, quase autônomo, que passou então a ser preenchido pela família.

Sambrook afirma, em seu livro The Eighteenth Century: The Intellectual and Cultural Context of English Literature 1700 - 1789, que o século XVIII foi um século de forte nacionalismo na Inglaterra devido aos avanços trazidos ao país pelas revoluções industrial e agrícola, que transformaram a vida, a paisagem e as estruturas sociais e políticas. Locke, em seu Two Treatises of Government publicado anonimamente em 1689, faz uma forte apologia à Revolução Gloriosa de 1688 defendendo a idéia de que os homens são livres, iguais e independentes em seu estado natural e que concordam em ceder parte de sua independência a

\footnotetext{
${ }^{45}$ ARIÈS, P. "Por uma história da vida privada". In: ARIÈS, P. CHARTIER, R., org. História da Vida Privada: da Renascença ao Século das Luzes. São Paulo, Companhia das Letras, 2006. v. 3, p. 16.

${ }^{46}$ Id., ibid., p. 17.
} 
um governante que irá proteger e regular a instituição da propriedade privada julgando conflitos, mas que qualquer abuso arbitrário sobre este direito por parte de um governante confere ao subordinado a possibilidade de transferir sua lealdade a outro governante. ${ }^{47}$ Segundo Locke, o objetivo do governo é preservar a propriedade privada: direito assegurado ao homem por seu trabalho. Uma vez que os recursos naturais são oferecidos a todos por Deus, o trabalho que o homem executa sobre eles garante-lhe o direito de posse sobre sua produção.

Nestas palavras observamos a importância que passa a ser atribuída ao contexto privado da vida em detrimento do público, colocando o particular acima do coletivo. Isto se manifesta não somente no conceito da propriedade privada, mas também na supremacia do indivíduo livre, que se submete não por imposição, mas por sua própria vontade.

\subsection{A centralidade do espaço em Pamela}

Embora Pamela se caracterize como um romance da ficção doméstica, o espaço em Pamela não está restrito ao ambiente da casa, ele permeia toda a narrativa influenciando o modo como as personagens se relacionam. Na passagem a seguir notamos que nossos protagonistas habitam um mundo estratificado em que os relacionamentos se dão a partir de posições espaciais previamente estabelecidas, e que Pamela tem clara ciência do lugar que ocupa nesse mundo:

“ 'Have I done you any harm?' 'Yes, sir,' said I, 'the greatest harm in the world: You [...] have lessened the distance that fortune has made between us, by demeaning yourself, to be so free to a poor servant." ",48

O uso da palavra distance neste trecho revela o grande peso atribuído ao espaço no romance. Uma vez que as relações entre a criada e o patrão se dão a partir de um entendimento espacial do mundo, a distância social que existe entre eles assume também um caráter físico. Segundo Pamela, ao demonstrar seu interesse por uma criada ou, em outras palavras, ao se aproximar fisicamente da jovem, Mr B. se coloca no mesmo nível que ela diminuindo também a distância social que os separa, pois a aproximação física que ele busca ao abraçá-la e beijá-la é inadequada às posições que os dois ocupam na sociedade. Este

\footnotetext{
${ }^{47}$ SAMBROOK, J. The Eighteenth Century: The Intellectual and Cultural Context of English Literature 1700 1789. 2ed. London, Longman, 1994. p. 87.

${ }^{48}$ Pamela, carta XI, p. 55.
} 
trecho demonstra que o relacionamento entre as personagens se pauta em um entendimento espacial do mundo, em que as pessoas ocupam posições relativamente fixas na sociedade e a partir da qual se relacionam com os outros.

Além disso, os lugares mencionados no romance estão imbuídos de emoções, o que lhes confere uma acentuada importância. Pamela, por exemplo, se refere à primeira tentativa explícita de sedução de Mr B. como "the summer-house affair"49 ou ao episódio em que ela se veste como uma camponesa dizendo " "he [Mr B.] does not love to hear of the summerhouse and the dressing-room" ${ }^{50}$. De onde se pode concluir que "Places and not actions take on the strongest attributes." 51

Referindo-nos novamente ao texto A Room of Pamela's Own de Robert Folkenflik, o autor afirma haver três tipos distintos de espacialização no romance: a hierarquia social e a distância que esta infringe às personagens, a distribuição dos cômodos da casa e o próprio corpo de Pamela. A subversão de um destes espaços implica a subversão de todos os outros. Assim sendo, Pamela passa toda a primeira parte do romance buscando encontrar um espaço privado em que possa estar protegida dos assaltos à sua integridade física, moral e social. No âmbito da casa este espaço é o closet, mas devido aos constantes ataques e intrusões de $\mathrm{Mr}$ B., o único espaço em que Pamela pode de fato se refugiar é o espaço de sua mente, sua consciência, sua interioridade, manifestado exteriormente como o espaço de sua escrita.

Neste ponto buscaremos um paralelo com as teorias de Locke e Newton, tão em voga no século XVIII. As inovadoras descobertas de Newton sobre a natureza, publicadas em seu livro Philosophiae Naturalis Principia Mathematica de 1686, trouxeram profundas mudanças à constituição da vida na época e uma nova orientação à ciência. A descoberta de que uma única e simples fórmula matemática pudesse explicar diferentes fenômenos da natureza maravilhou não só a comunidade científica e artística, bem como, e principalmente, um grande número de leigos que lotava as coffee-houses para assistir a palestras sobre os sistemas newtonianos ministradas por seus discípulos. Estes foram responsáveis por uma popularização da ciência, produzindo versões simplificadas das teorias de Newton e expondo-as ao público em geral. Além de suas descobertas sobre a mecânica celeste, Newton também realizou importantes estudos sobre a luz e as cores, publicados em seu livro Opticks de 1704. Nele Newton expõe a teoria de que todas as cores estão contidas na luz branca e que elas são de fato vibrações que se propagam no ar que, ao atingir o sensório (o centro nervoso

\footnotetext{
${ }^{49}$ Pamela, carta XXV, p. 93.

${ }^{50}$ Pamela, carta XXV, p. 94.

${ }^{51}$ FOLKENFLIK, 1972, p. 587.
} 
sensorial), transformam-se em sensações sob a forma de cores. A imagem de Newton com seu prisma realizando experimentos em sua câmara escura tornou-se uma das imagens mais populares da época.

Semelhantemente, a filosofia também se tornou mais acessível ao público no século XVIII, graças principalmente aos periódicos que publicavam textos filosóficos com um viés científico. Influenciada pelos cientistas contemporâneos, a filosofia buscava adquirir o mesmo grau de certeza em suas investigações e se preocupava em estudar a relação entre a mente e a matéria. Em An Essay Concerning Human Understanding, publicado em 1690, Locke busca compreender a conhecimento humano de forma científica, não através de uma sistematização do mundo da mente como Newton sistematizou o mundo da matéria, ou seja, ele não se ocupa da forma física da mente, mas da compreensão humana. Para tal ele se vale do conceito de idéia. Locke define 'idéia' como tudo aquilo que é objeto da compreensão do pensamento humano e compara as idéias a figuras presentes na mente. Para Locke, a mente seria como uma câmara escura, em um paralelo com a câmara escura de Newton. Em seu livro sobre o contexto intelectual e cultural do século XVIII, James Sambrook afirma em seu capítulo sobre a filosofia: "At one point he [Locke] takes the camera obscura (so valuable to Newton) as a model for the way in which such pictures are painted in the mind" e continua com uma citação do próprio Locke “...'methinks the Understanding is not much unlike a Closet wholly shut from light, with only some little openings left, to let in external visible Resemblances, or Ideas of things without'.,52

Nesta citação podemos ver a estreita relação que Locke estabeleceu entre a mente e o closet, a mente vista como um quarto escuro com apenas algumas aberturas que permitem a comunicação com o mundo exterior. No romance é clara a ligação entre o closet, onde a personagem se refugia para chorar, orar, escrever suas cartas ou alegrar-se, e a mente de Pamela, onde ela elabora suas idéias, isola-se em seus pensamentos e cria soluções reais ou fantasiosas para seus problemas. Sob este entendimento, a mente representa o espaço da elaboração das idéias, da ordenação das impressões adquiridas no mundo e da busca de soluções através do uso e do domínio da razão. Analogamente, o closet é o espaço em que a personagem organiza seus pensamentos e as impressões do mundo externo através do ato da escrita.

Além disso, Locke acreditava que a mente era como um sentido interno ou uma tabula rasa que obedecia às condições de seu ambiente de modo que, ao modificar o

\footnotetext{
${ }^{52}$ SAMBROOK, 1994, p. 60.
} 
ambiente, tornava-se possível transformar a mente ou a natureza da pessoa, atribuindo uma forte importância à constituição espacial e ao espaço da introspecção.

Referindo-nos novamente aos três tipos de espacialização de Folkenflik, observamos que a posição de Pamela dentro da estrutura estratificada de mundo em que vivem as personagens é clara até a morte de sua senhora, quando $\mathrm{Mr} \mathrm{B}$. assume o controle das propriedades e da família. A partir daí a ordem espacial da casa é pervertida juntamente com os valores e as atitudes. Pamela perde sua função de dama de companhia e sua posição dentro da estrutura espacial em que se dão as relações humanas, conseqüentemente ela perde também seu espaço dentro da casa. O closet de sua senhora, antes um espaço de recolhimento e privacidade, passa a estar sob o domínio e as ordens de Mr B. e com isso seu acesso a ele torna-se irrestrito, como notamos na abertura de uma das cartas de Pamela a seus pais logo no início do romance:

\section{"LETTER XV}

My dear Mother,

I broke off abruptly my last letter; for I feared he was coming; and so it happened. I put the letter into my bosom, and took up my work, which lay by me;",53

Esta, no entanto, não é a única mudança que ocorre no arranjo espacial da casa após da morte da senhora. Pamela, advertida pelo pai quanto às intenções de Mr B. e após o ataque sofrido na summer-house, passa a dormir no quarto da governanta, Mrs Jervis, como vemos na passagem a seguir:

\footnotetext{
"In this perplexity; now considering, now crying, and not knowing what to do, I passed the time in my chamber till evening; when desiring to be excused going to supper, Mrs Jervis came up to me, (...) I begged I might be permitted to lie with her on nights; for I was afraid of spirits, and they would not hurt such a good person as she. 'That was a silly excuse,' she said; 'for why was you not afraid of spirits before?' [Indeed I did not think of that]. 'But you shall be my bed-fellow with all my heart,' added she, 'let your reason be what it will;', ",54
}

Com a morte da senhora, não apenas a hierarquia social e a distribuição dos espaços da casa são subvertidos, mas o terceiro tipo de espaço também o é: o corpo de Pamela. Mr B. é responsável por constantes ataques à integridade física da jovem, que considera as tentativas de sedução de $\mathrm{Mr}$ B. “... in terms of his invading a place where he does not

\footnotetext{
${ }^{53}$ Pamela, carta XV, p. 61.

${ }^{54}$ Pamela, carta XII, p. 57.
} 
belong..." ${ }^{55}$. Desta forma, com a perda de sua posição social e conseqüentemente de um espaço reservado dentro da casa, Pamela busca privacidade dentro de sua mente, sua câmara escura, seu closet interior.

Este espaço interior de Pamela se manifesta exteriormente como o espaço de sua escrita. Portanto, quando Mr B. invade o closet ou o quarto de Pamela, tal ato é visto como um aviltamento tanto a seu espaço social quanto ao espaço de seu corpo. Semelhantemente, quando Mr B. intercepta as cartas de Pamela a seus pais ou posteriormente quando exige ter acesso a seu diário, essa invasão é vista como uma tentativa de apropriação do espaço de sua mente, seu espaço interior. Folkenflik afirma que "Reading her [Pamela's] letters and raping her are presented as cognate activities. Rape is the ultimate threat to privacy." ${ }^{, 56}$ Para Pamela, portanto, a tentativa de invasão a seu corpo ou a sua mente é vista como uma invasão à sua privacidade. $^{57}$

Dada a importância do espaço da escrita em Pamela, tal ato assume um papel central no desenrolar da narrativa. Para John Pierce, a autoridade de Pamela deriva de seu texto. Devido à sua pouca idade, sua condição social e ao fato de ser mulher, Pamela não pode exercer sua autoridade. Ela o faz, portanto, através do ato da escrita. Nela encontram-se manifestadas sua identidade e seu poder, e através dela Pamela confere credibilidade à sua história tornando os acontecimentos tangíveis e verdadeiros, a fiel expressão de seus sentimentos e de seu sofrimento, segundo o seu próprio entendimento.

De modo a reforçar esta autoridade, Pamela recorre às fábulas e à Bíblia, citando trechos e fazendo referências a histórias, situações e personagens que povoam essa literatura. Sua adaptação do salmo 137 é um bom exemplo de como o leitor é levado a crer em seu sofrimento quando, em um jantar diante dos vizinhos e do pai de Pamela, Mr B. lê sua versão do salmo em comparação ao texto original ${ }^{58}$. Sobre este episódio, Pierce afirma,

"In this case, the reader is given conscious clues about how the text is to be read and the kind of agreed-upon authority it has within the fictional world of the novel. Although Mr B. controls the text at this point - it comes from his pocket - in the course of the scene it moves into the public domain and passes from a private text of personal suffering to a public account of heroic action.",59

\footnotetext{
${ }^{55}$ FOLKENFLIK, 1972, p. 585.

${ }^{56}$ Id., ibid., p. 586.

${ }^{57}$ Id., ibid, p. 587.

${ }^{58}$ A versão do salmo 137 encontra-se nas páginas 179 e 180 e a versão comparada ao original encontra-se nas páginas 349 a 353 do romance.

59 PIERCE, J B. "Pamela's Textual Authority". In: BLEWETT, David. Passion and Virtue: Essays on the Novels of Samuel Richardson. Toronto, University of Toronto, 2001. pp. 14-15.
} 
Analogamente, Pamela se apropria do mundo mágico das fábulas para imprimir um tom de veracidade a seu texto, uma vez que "The fable as adopted in Pamela offers a moral truth and common-sense wisdom compatible with the sacred truth of scripture and the empirical truth of history." ${ }^{60}$ Para Pierce, a própria história de Pamela se assemelha à fábula em seu intuito didático.

Este exercício de sua imaginação, criatividade e inteligência representa mais um dos inúmeros atributos da criada e faz dela uma moça distinta moldada à vida elegante e refinada. Além disso, o espaço de sua escrita oferece à jovem uma liberdade que lhe é negada na vida social. Confinada ao restrito espaço da casa, a que Mr B. tem total acesso, e, portanto, sem o direito à privacidade almejada, Pamela exercita sua autonomia e poder através do ato da escrita.

O grande triunfo da autoridade textual de Pamela é a reforma moral que se processa tanto em Mr B. quanto em sua irmã Lady Davers, após a leitura do diário da jovem. De fato, Pamela não prescinde de leitores que dão crédito à sua história e avalizam o poder de sua retórica, uma vez que tanto suas cartas quanto seu diário são endereçados aos pais. Contudo, o grande leitor dos escritos de Pamela é o próprio Mr B. Ao início do romance, ainda na mansão de Bedfordshire, ele intercepta suas cartas e posteriormente em Lincolnshire é depois de sua leitura, no diário da criada, sobre a tentativa frustrada de fuga empreendida por Pamela e suas considerações sobre pôr fim a seu sofrimento atirando-se ao lago, que $\mathrm{Mr} \mathrm{B}$. se enternece, reconhece seus verdadeiros sentimentos e decide casar-se com a jovem.

"He put the papers in his pocket, when he had read my reflections, and my thanks for escaping from myself; and said, taking me about my waist, 'O my dear girl! you have touched me sensibly with your mournful tale, and your reflections upon it."61

Também na visão de Michael McKeon, o poder de Pamela reside em sua retórica, no poder de persuasão que a escrita lhe confere:

"Pamela's power as a writer depends entirely on B.'s availability as a reader. And this is paradoxical, because his access to her letters (...) is a major source of his knowledge of and power over her. Indeed, this is how Pamela herself sees it. Once imprisoned in Lincolnshire, the fact of her solitude is borne home to her as the absence of an audience, as the fact that even though she can write, she cannot be read." ${ }^{, 62}$

\footnotetext{
${ }^{60}$ Id., ibid., p. 20.

${ }^{61}$ Pamela, diário, p. 276.

${ }^{62}$ MCKEON, M. The Origins of the English Novel: 1600-1740. 15 ${ }^{\text {th }}$ anniversary edition. Baltimore, John Hopkins, 2002. p. 361.
} 
De fato, pode-se notar certa satisfação da jovem quando seu diário torna-se primeiramente objeto de leitura e posteriormente o elemento que permite que Mr B. e Lady Davers passem a vê-la com outros olhos. Durante boa parte do romance Lady Davers é frontalmente contra o envolvimento amoroso de seu irmão com a criada. Em carta endereçada a Mr B., ela expõe veementemente seus sentimentos quando afirma:

"Consider, brother, that ours is no upstart family. It is as ancient as the best in the kingdom: and for several hundreds of years, it has never been known, that the heirs of it have disgraced themselves by unequal matches: (...) If you were descended from a family of yesterday, from one who is but a remove or two from the dirt you seem so fond of, that would be another thing." $" 63$

Neste trecho podemos salientar o uso das palavras "disgraced" e "dirt" que revelam com bastante intensidade e crueza a dura opinião da aristocracia pelas classes menos favorecidas. Contudo, também ela, Lady Davers, é obrigada a render-se à honestidade e à virtude de Pamela, e finalmente, após a leitura de seu diário, admitir à sua dama de companhia:

“" 'Tis a charming creature, Worden! I know not which excels, her person or her mind. So young a creature! Well may my brother love her! ",64

Ambos Pierce e McKeon associam o poder de Pamela à sua autoridade textual. No entanto, para McKeon, além do poder da retórica de Pamela, presente em seu diário, são também a exposição persuasiva de seus sentimentos, sua virtude de caráter e sua bondade que provocam a mudança de atitude tanto da parte de Mr B. quanto da parte de Lady Davers.

Pierce, por sua vez, considera que a estratégia do discurso da criada consiste na apropriação de textos didáticos de grande valor moral mesclados com o alto apelo emotivo de sua história. Assim Pierce conclui:

"Pamela's letters and journal demonstrate that an authoritative account containing a truthful representation of human experience is not reducible either to the exactness of referential truth or to the subjectivism of entirely personal truth. The former is the truth of a tyrant; the latter, that of an egoist. Pamela's authority derives from the assimilation of universal forms to the honesty of human sentiment." ${ }^{\prime 65}$

Outros críticos literários se detiveram sobre o uso da retórica nos textos de Richardson. Dentre eles podemos destacar Tom Keymer que, em seu livro Richardson's

\footnotetext{
${ }^{63}$ Pamela, diário, p. 293.

${ }^{64}$ Pamela, diário, p. 476.

65 PIERCE, 2001. p. 26.
} 
Clarissa and the Eighteenth-Century Reader, nos oferece uma profunda análise sobre a forma epistolar, a forma escolhida por Richardson para contar suas histórias. O ponto central de seu estudo é a co-responsabilidade do leitor na construção do significado do texto. Tal idéia pode parecer contraditória se nos damos conta do objetivo didático a que se propõe Richardson. Este objetivo fica bastante claro desde o prefácio de Pamela quando o escritor se apresenta não como o autor de uma história de ficção, mas sim como o editor de uma história real que escolhe torná-la pública com o intuito de:

"If to divert and entertain, and at the same time to instruct and improve the minds of the YOUTH of both sexes:

If to paint VICE in its proper colours, to make it deservedly odious; and to set VIRTUE in its own amiable light, to make it look lovely: [...]

If these be laudable or worthy recommendations, the Editor of the following Letters, which have their foundation both in Truth and Nature, ventures to assert, that all these ends are obtained here, together.",66

Contudo, para Keymer, a intenção didática de Richardson é muito mais sutil do que se pode supor, já que as lacunas deixadas no texto, devido à escolha da forma epistolar, fazem do leitor uma espécie de co-autor: não um leitor passivo que absorve a história irrefletidamente, mas um leitor ativo cuja responsabilidade é retirar o significado oculto do texto de modo a absorver seu conteúdo moral e didático.

Keymer inicia seu estudo afirmando que o próprio gênero contém um padrão de interação mais complexo, que explora a relação autor - leitor como uma forma de comunicação recíproca entre ambos, como se o romance fosse uma "conversa familiar" onde o autor entretém o leitor com sua narrativa ${ }^{67}$. No caso de Richardson, a situação é ainda mais intricada, pois o leitor não tem acesso à história através de um narrador destacado que lhe conta uma história na qual não está diretamente envolvido, mas de um narrador que se dilui na narração dando assim a impressão de que a história chega até ele de forma direta, sem mediação.

No caso de Pamela, somos atirados ao mundo desta bela e jovem criada, através de seus próprios olhos. Nossa visão está submetida à dela e do início ao final do romance nosso acesso aos sentimentos ou pensamentos das personagens se dá sempre através dos olhos e da pena de Pamela.

\footnotetext{
${ }^{66}$ Pamela, prefácio, p. 31.

${ }^{67}$ KEYMER, T. Richardson's Clarissa and the Eighteenth-Century Reader. Cambridge, Cambridge University, 1992. p. xiii.
} 
Mesmo quando transcreve as cartas de $\mathrm{Mr} \mathrm{B}$, ou de seus pais, elas chegam até nós através da narrativa de Pamela. Com a história narrada por um "narrador-protagonista"68, o leitor se vê atado às mãos de Pamela, pois os fatos da história chegam a ele através de sua narração.

Um dos elementos a que a forma do romance está submetida é a presença de um narrador. A escolha do tipo de narrador e de como este irá contar sua história confere à obra muitas de suas características essenciais e norteia o rumo que deverá tomar a narrativa. Essencialmente um narrador pode contar sua própria história ou a história de alguém, e pode escolher fazê-lo de vários modos. Ao contar sua própria história, por exemplo, pode fazê-lo no momento em que ela se desenrola ou em retrospectiva. Ao contar a história de outra pessoa pode fazê-lo de maneira imparcial ou preenchê-la com seus comentários e opiniões. Pode mostrar a perspectiva de apenas uma personagem ou o ângulo de visão de várias personagens. Ele atua como um filtro entre o leitor e a história narrada. De tal forma que os leitores de um romance se vêem em suas mãos, presos à sua habilidade ou inabilidade de narrar.

\subsection{Narrador e modo narrativo}

Em Pamela, a visão parcial do narrador-protagonista nos obriga a ver o mundo através de sua perspectiva e somente uma leitura mais atenta pode revelar os traços da personagem escondidos pela narração. Segundo Friedman, "O narrador-protagonista encontra-se quase que inteiramente limitado a seus próprios pensamentos, sentimentos e percepções." ${ }^{\circ 9}$ Assim está também o leitor, limitado ao saber do narrador.

Desde as primeiras linhas de Pamela, o leitor é introduzido à trama narrativa e às personagens através do filtro de nossa narradora-protagonista, como se pode observar no parágrafo que abre romance:

"My dear Father and Mother,

I have great trouble, and some comfort, to acquaint you with. The trouble is, that my good lady died of the illness I mentioned to you, and left us all much grieved for the loss of her; for she was a dear lady, and kind to all us her servants."

\footnotetext{
${ }^{68}$ FRIEDMAN, N. "O Ponto de Vista na Ficção: o Desenvolvimento de um Conceito Crítico". Revista USP. São Paulo, n. 53, março / maio 2002. p. 176.

${ }^{69}$ Id., ibid., p. 177.

${ }^{70}$ Pamela, carta I, p. 43.
} 
Esta visão parcial e oblíqua, a visão de um 'eu' que enxerga as coisas à sua volta a partir de seu próprio centro, permeia todo o romance. Desde as primeiras palavras percebemos claramente a visão limitada do narrador a que o leitor deve se submeter. É ele quem dá o tom à história, é a partir de sua percepção das coisas que o leitor sabe dos fatos. $\mathrm{O}$ leitor está limitado àquilo que o narrador deseja revelar, àquilo que deseja salientar ou omitir, de acordo com a predisposição de seu momento.

Em um romance em que a narração se dá em primeira pessoa, estas escolhas são ainda mais urgentes. Desde os pronomes 'I' ou 'my' até as intervenções explícitas, como a grafia em itálico de algumas palavras que concentram em si significados importantes para a compreensão dos sentimentos do narrador, tudo chega ao leitor através de seu filtro. Sem falar na escolha das próprias palavras com que a história será narrada.

"I broke off abruptly my last letter; for I feared he was coming; and so it happened. I put the letter into my bosom, and took up my work, which lay by me; but I had so little of the artful, as he called it, that I looked as confused, as if I had been doing some great harm.",71

O que dizer, por exemplo, do uso das palavras abruptly, fear, ou harm, que induzem o leitor a se identificar com o sentimento de pânico pelo qual passa nossa narradoraprotagonista? Ou ainda, o uso da palavra confused que sintoniza o leitor com a confusão mental de Pamela? Se todo narrador é um mediador entre o leitor e a história narrada, muito mais frágil é esta relação quando o narrador está comprometido com sua própria história.

De acordo com Wayne Booth, a distinção entre narrador em primeira ou terceira pessoa não é tão crucial quanto se costuma crer. Segundo sua interpretação, a real diferença se dá entre o narrador dramatizado e o não-dramatizado. Por narrador dramatizado, entendese todo aquele narrador que é parte integrante de uma história. Para ele, todo narrador em primeira pessoa é um narrador dramatizado, que pode se dividir entre narrador-observador e narrador-agente. No caso de Pamela, segundo esta perspectiva, estamos diante de um narrador dramatizado que é agente de sua própria história. Conforme a teoria de Booth, "In fiction, as soon as we encounter an 'I', we are conscious of an experiencing mind whose views of the experience will come between us and the event."72

\footnotetext{
${ }^{71}$ Pamela, carta XV, p. 61.

${ }^{72}$ BOOTH, W. The Rhetoric of Fiction. 2 ed. Chicago, University of Chicago, 1983. pp. 151-152.
} 
A partir de tal ponto de vista, fica difícil ao leitor estabelecer um parâmetro de julgamento dos fatos e do caráter das personagens. Tomemos como exemplo o caso de $\mathrm{Mr} \mathrm{B}$. Logo ao início do romance quando o senhor se mostra afável e gentil para com Pamela, ele é:

".... fine gentleman, as every body, indeed, says he is: but he gave these good things to us both with such a graciousness, that I thought he looked like an angel., ${ }^{, 73}$

Algumas páginas mais tarde no romance, depois de assediá-la na summer-house, ele se transforma em um:

“...wicked gentleman as he is!",74

Para novamente, ao casar-se com ela ao final do romance, se tornar seu "best friend" "75 "the best of husbands",76, ou ainda "this most generous of husbands"77.

Fica bastante claro, nos exemplos acima, que o narrador-protagonista "narra de um centro fixo, limitado quase que exclusivamente às suas percepções, pensamentos e sentimentos." ${ }^{, 78}$ Pode-se concluir, portanto, que o narrador no caso de Pamela, é em si pouco confiável. Ele busca induzir o leitor a pensar e a sentir como ele, a identificar-se com sua visão parcial dos fatos, com sua própria perspectiva tendenciosa. Como nos diz Wayne Booth,

"Unreliable narrators [...] differ markedly depending on how far and in what direction they depart from their author's norms; [...] Some narrators are placed as far 'away' from author and reader as possible, in respect to every virtue except a kind of interesting vitality. Some come close to representing the author's ideal of taste, judgment, and moral sense. All of them make stronger demands on the reader's powers of inference than do reliable narrators." 79

O narrador não confiável, portanto, conta com a simpatia do leitor em assumir como verdade sua narração dos fatos. Ainda segundo Booth, “...the deeper our plunge, the more unreliability we will accept without loss of sympathy." 80 De tal forma que se torna mais difícil manter a ironia, ou distanciamento crítico, ao envolver-se em uma história contada por um narrador comprometido.

\footnotetext{
${ }^{73}$ Pamela, carta VI, p. 50.

${ }^{74}$ Pamela, carta XIV, p. 61.

75 Pamela, diário, p. 400.

${ }^{76}$ Pamela, diário, p. 386.

${ }^{77}$ Pamela, diário, p. 513.

${ }^{78}$ LEITE, L. C. M. O Foco Narrativo: ou a Polêmica em Torno da Ilusão. 10 ed. São Paulo, Ática, 2005. p. 43.

${ }^{79}$ BOOTH, 1983, p. 159.

${ }^{80}$ Id., ibid., p. 164.
} 
Assim Pamela sofre e busca a identificação do leitor com seu sofrimento. Contudo, grande parte das contradições do romance advêm da escolha de um narrador que nos irá apresentar sua própria história. Desde o título, o leitor sabe que esta é uma história sobre a “virtude recompensada". Na primeira página da edição de 1801, edição definitiva do romance publicada postumamente com as revisões finais do autor e que serve de base a este trabalho, o autor informa que esta publicação tem a intenção de:

"...cultivate the principles of virtue and religion in the minds of the youth of both sexes." $" 81$

Esta idéia está veementemente expressa nas falas de nossa narradora-protagonista a ponto de observarmos que o próprio substantivo virtue e suas derivações virtuous e virtuously aparecem mais de cem vezes ao longo do romance. Sendo assim, Pamela é a porta-voz da virtude, da caridade, da religiosidade, do perdão, da modéstia e de tantas outras qualidades de uma jovem praticamente perfeita, não fosse pela contradição inerente entre suas palavras e seu modo de agir.

Numa das primeiras cartas a seus pais, depois de ter sido advertida quanto às possíveis intenções escusas de Mr B com relação a ela, Pamela afirma:

"I will die a thousand deaths, rather than be dishonest any way. Of that be assured, and set your hearts at rest; for although I have lived above myself for some time past, yet I can be content with rags and poverty, and bread and water..." 82

Várias vezes, no romance, Pamela professa sua modéstia:

“...though I have nothing to say but what will make me look more like a vain hussy, than any thing else: however, I hope I shan't be so proud as to forget myself." ${ }^{\prime 83}$

Na carta IX, Pamela afirma não ter dito nada ainda a Mrs Jervis sobre o episódio no jardim, quando Mr B. rouba-lhe um beijo na summer-house:

“...for fear she should think me presumptuous, and vain, and conceited..." 84

\footnotetext{
${ }^{81}$ Pamela, página de rosto da edição de 1801.

${ }^{82}$ Pamela, carta III, p. 47.

${ }^{83}$ Pamela, carta IV, p. 47.

${ }^{84}$ Pamela, carta IX, p. 53.
} 
Contrariamente a esta determinação, Pamela anuncia sua beleza praticamente a cada página. É certo que nunca pelas próprias palavras, mas, a cada nova carta, Pamela afirma ter sido elogiada, por sua beleza ou por sua retidão de caráter. Para Mrs Jervis, Pamela é:

“...one of the most virtuous and industrious creatures she [Mrs. Jervis] ever knew."

Para Lady Davers, a irmã de Mr B., Pamela é:

“...a very pretty wench, and that every body gave me [Pamela] a very good character, and loved me;",86

As vizinhas de Mr B. em Bedfordshire querem conhecer Pamela, pois é sabido na região que $\mathrm{Mr}$ B. tem uma criada que é

“...the greatest beauty in the county;",

Até Mrs Jewkes, a governanta má da mansão de Lincolnshire, elogia Pamela ao falar do interesse de Mr Williams, o pároco, por ela:

"...he will be very glad, to be sure, to be obliged to him for a wife of his chusing; especially such a pretty one, and one so ingenious, and genteelly educated." 88

Mais tarde no romance, quando os vizinhos de Mr B. em Lincolnshire vêm visitá-lo para conhecer Pamela, ela conta que:

"My master told me, that Mrs. Jones said, 'She is a charming creature! I see that at this distance.' And Sir Simon, it seems, who has been a sad rake in his younger days, swore he never saw so easy an air, so fine a shape, and so graceful a motion. Lady Darnford said, I was a sweet girl. And Mrs. Peters said very handsome things. Even Mr. Peters said, I should be the pride of the county. The young ladies, he was pleased to add, blushed, and envied me!"89

Outros relatos semelhantes inundam as páginas do romance. Até a própria Pamela chega a admitir:

${ }^{85}$ Pamela, carta XIV, p. 60.

${ }^{86}$ Pamela, carta IV, p. 47.

${ }^{87}$ Pamela, carta XXIII, p. 82.

${ }^{88}$ Pamela, diário, p. 181.

${ }^{89}$ Pamela, diário, p. 321. 
"Will you forgive your vain daughter, if she tells you all he was pleased to tell me? Vain you will think me, and I cannot but say I am proud to be so distinguished by him.. ${ }^{90}$

Além disso, por ter sido trazida à casa de Mr B. ainda menina, com menos de doze $\operatorname{anos}^{91}$, sua senhora, a quem Pamela servia como dama de companhia, ensinou a criada a dançar e a cantar, a recitar salmos, a apreciar literatura, a tocar harpa, a preparar arranjos de flores, a desenhar, a bordar, a servir à mesa. Em outras palavras, Pamela possui todas as qualidades de uma fina dama da sociedade da época. Seu pai afirma que

"Every body talks how you are come on, and what a genteel girl you are; and some say, you are very pretty;",

Não são apenas as falas das personagens que nos fazem questionar a inocência e falta de interesse da jovem. Há outros exemplos no texto que fazem o leitor duvidar de sua tão anunciada virtude de caráter. Ao ser apresentada a um senhor suíço que tinha sido contratado por Mr B para vigiá-la, Pamela reporta em seu diário:

"Monsieur Colbrand, [...] in broken English, told me, I was happy in de affections of de vinest gentleman in de varld!"93

em uma clara referência a seu sotaque.

Diante de tais evidências, fica difícil aceitar as virtudes de Pamela sem questionar seu comportamento. Estamos aqui diante de um caso da interferência de um autor implícito. De fato, um autor nunca desaparece por completo de uma história. Na escolha entre o quê e como contar sua história, entre contar ou mostrar os fatos ou de que maneira fazê-lo, revelase a presença de um autor implícito.

Devemos o conceito de autor implícito a Wayne Booth. Para ele, “...the author's judgment is always present, always evident to anyone who knows how to look for it. Whether its particular forms are harmful or serviceable is always a complex question..." Contudo, o que não podemos esquecer é que "...though the author can to some extent choose his disguises, he can never choose to disappear." 94

\footnotetext{
${ }^{90}$ Pamela, diário, p. 320.

${ }^{91}$ Pamela, carta XII, p. 57.

92 Pamela, carta II, p. 45.

${ }^{93}$ Pamela, diário, p. 206.

${ }^{94}$ BOOTH, 1983, p. 20.
} 
Portanto, podemos dizer que a insistência de Richardson, não o homem, mas o autor implícito à obra, em fazer de Pamela uma jovem exemplar busca retirar dela toda e qualquer falha que pudesse desabonar seu caráter de alguma forma. Porém, a própria representação cria situações que fogem a seu controle e fazem desta uma personagem realisticamente convincente, pois ninguém é inteiramente bom ou mau. Por mais que queira é impossível ao autor determinar previamente a reação do leitor ao ler um romance e o julgamento que fará das personagens. Na verdade, são exatamente as ambigüidades internas da obra que tornam a leitura de um romance como Pamela ainda interessante nos dias de hoje, mais de duzentos e cinqüenta anos após sua primeira publicação.

Embora muitos autores afirmem escrever para si próprios, ou pelo simples prazer de escrever, parte-se do princípio que tudo aquilo que é escrito poderá ser lido um dia. Logo, toda literatura está contaminada pela retórica, pela fala que busca persuadir o leitor a crer nesta ou naquela idéia. Para muitos críticos e autores, admitir que a literatura esteja inundada pela retórica é diminuir seu valor. Booth, porém, é de opinião que, "If the most admired literature is in fact radically contaminated with rhetoric, we must surely be led to ask whether the rhetoric itself may not have had something to do with our admiration." 95 Diante destes fatos cabe ao leitor deixar-se convencer ou não, e ao crítico, buscar desnudar as "impurezas"96 da obra.

No caso de Pamela, a dificuldade de uma leitura mais distanciada não reside somente na escolha, por parte do autor, de um narrador-protagonista, mas também da forma epistolar, que confere à narração uma espécie de opacidade impedindo uma visão mais transparente dos fatos.

Valendo-nos mais uma vez da teoria de Keymer, ele afirma em seu estudo que a forma da carta nos leva a crer que este tipo de escrita é naturalmente conducente à expressão dos sentimentos mais íntimos de um indivíduo graças à informalidade de seu conteúdo e estilo, e à sua limitada recepção, que presume um leitor íntimo e amigo. É como se, na leitura de uma carta, os homens aparecessem despidos de qualquer falsidade e expusessem, de maneira absolutamente confiável, o mais íntimo de seu ser.

Keymer, contudo, não se deixa levar por este efeito de absoluta confiabilidade, pois para ele a carta predispõe à manipulação do leitor por parte do autor, partindo do princípio que este conhece mais intimamente as predisposições daquele a quem escreve e, portanto, esta manipulação se torna menos árdua e mais provável. Desta forma, ele enfatiza a

\footnotetext{
${ }^{95}$ Id., ibid., pp. 98-99.

${ }^{96}$ Id., ibid., p. 99.
} 
necessidade de uma leitura crítica da narrativa epistolar que tenha sempre em vista o distanciamento da espontaneidade da fala e da desinteressada exposição dos acontecimentos e dos sentimentos de quem escreve.

No caso de uma narrativa toda desenvolvida a partir de cartas, como é o caso de Pamela, a questão de sua confiabilidade e da indeterminação da realidade que retrata é ainda mais grave, já que a interpretação dos fatos depende única e exclusivamente da expressão de seu conteúdo.

Em Pamela, nossa jovem escritora afirma e reafirma, carta após carta, a veracidade de seu relato e a honestidade de seus sentimentos, como podemos observar nos trechos a seguir:

\footnotetext{
“ 'I am not afraid, sir,' said I, 'of being found guilty of a falsehood in what I have told you. I remember not all I wrote, yet I know I wrote my heart at the time; and that is not deceitful." ",97

“ ‘...since I have only writ the truth;', ,98
}

Os leitores de Pamela dentro do romance, seus pais, Lady Davers e principalmente $\mathrm{Mr}$ B., terminam por assumir como verdade o conteúdo de sua escrita. Keymer afirma sobre $\mathrm{Mr}$ B.: "The point is conceded in the end even by Mr B., who comes to value the letters precisely for their confessional quality, and for what seems an innocence of rhetorical intent." 99

Keymer, no entanto, vê a retórica de Pamela como tendenciosa devido à grande insistência da própria personagem em afirmar diversas vezes a sinceridade de seu relato e na exposição do conflito entre a evidente maldade de $\mathrm{Mr}$ B. em contraste com sua própria bondade, já que a personagem busca passar uma imagem de perfeita retidão em oposição à impulsividade, astúcia e engenhosidade de Mr B.

Assim sendo, a ambigüidade criada entre forma e conteúdo deixa o leitor com sérias dificuldades de absorver a mensagem da história, abrindo caminho a duas possíveis interpretações. É possível se fazer uma leitura ingênua de Pamela tomando-a como ela se apresenta a nós, ou seja, como a personificação de pureza, inocência, lealdade e virtude, como a pobre moça virtuosa que sofre constantes ataques à sua honestidade, ou da maneira oposta a essa, que vê a personagem como uma jovem ardilosa e perspicaz que reconhece o interesse de Mr B. e se vale de sua beleza, inteligência e influência para manipular as pessoas de seu convívio mais íntimo e atingir seu objetivo último de ascensão social.

\footnotetext{
${ }^{97}$ Pamela, diário, p. 266.

${ }^{98}$ Pamela, diário, p. 273.

${ }^{99}$ KEYMER, 1992, p. 20.
} 
Este foi um dos problemas com que Richardson teve que se defrontar quando da publicação do livro: dois diferentes grupos de leitores se formaram, os pró Pamela, chamados Pamelists, e os contra Pamela, chamados Antipamelists. O primeiro grupo se compunha de leitores leais, dispostos a aceitar Pamela como ela se apresenta no romance. Para eles, as cartas professam veracidade e espontaneidade e constituem a expressão do mais íntimo de seu ser. O segundo grupo foi responsável por subverter a idéia inicial da virtuosidade da jovem e descobrir, por baixo da leitura superficial, uma Pamela hipócrita, ardilosa e conhecedora da arte da sedução. Estes outros leitores, por sua vez, vêem as cartas como um instrumento de retórica e persuasão, presentes no próprio fato da premeditação intrínseca ao ato da escrita.

Na verdade, se Pamela é bem ou mal intencionada é uma pergunta que se manteve sem resposta ao longo dos anos. Contudo, o que nos interessa literariamente não é extrair do texto indícios que comprovem a inocência ou culpabilidade da protagonista, mas sim observar as restrições impostas pela forma escolhida pelo autor para relatar sua história. A forma epistolar pressupõe essa ambigüidade de sentido. Cabe ao leitor, portanto, buscar compreender Pamela de modo mais profundo. Não somente ler e interpretar a personagem nas entrelinhas, tentando captar suas intenções ocultas, escondidas até dela mesma, mas principalmente ler as cartas como uma escrita retórica em que o autor determina previamente de que forma deseja ser interpretado pelo leitor na tentativa de persuadi-lo a crer naquilo que deseja. Toda escrita, por seu próprio caráter privado e reflexivo, pressupõe a ponderação das idéias que exprime, podendo assim ser vista como uma premeditada manipulação do autor do modo como este deseja ser lido pelo leitor.

É responsabilidade do leitor neste caso procurar as fissuras do texto para dar sentido à sua mensagem subliminar. Aqui nos colocamos diante de outro problema. Não somente Pamela pode ser lida de diferentes maneiras, mas também Richardson recebeu as mais diversas críticas.

Para muitos, desde Coleridge, há uma grande distinção entre Richardson, o homem, e Richardson, o autor. A admiração pelo pioneirismo da ficção de Richardson muitas vezes entra em conflito com a aparente banalidade de seu caráter e da simples motivação didática implícita às suas obras. Sobre o caráter de Richardson, Brissenden afirma, "it is impossible to regard Richardson himself as a great man." ${ }^{100}$ No entanto sobre sua obra ele diz, "Pamela and Sir Charles Grandison are important books, and Clarissa is a great one."101 Muitos são

\footnotetext{
${ }^{100}$ BRISSENDEN, 1965, p. 9.

${ }^{101}$ Id., ibid., p. 9.
} 
os críticos que reconhecem o alcance de sua obra de ficção, mas igualmente muitos julgam que esta criação se deu quase que por acaso. Citando novamente Brissenden:

"It seems clear that when Richardson began to write Pamela he had no great understanding or control of the conflicting inner forces he was about to release. In a very real sense he did not know what he was doing: almost without his realizing it his simple moral tract somehow turned into a novel."102

A idéia para o romance Pamela, sua primeira história, publicada no auge de sua maturidade aos cinqüenta e um anos de idade, surgiu enquanto Richardson trabalhava sobre um livro de cartas, cuja publicação tinha sido encomendada à sua casa editora com o objetivo de difundir o hábito da correspondência íntima e familiar. Com a criação dos correios no final do século XVII, este era um serviço que se estabelecia na época como eficiente, rápido e barato. No entanto, para que seu uso fosse ampliado era necessário um número maior de correspondentes regulares.

Durante a compilação e redação deste livro de cartas, intitulado Letters Written to and for Particular Friends, On the Most Important Occasions, mais comumente conhecido como Familiar Letters ${ }^{103}$, publicado em 1741, Richardson se deparou com uma carta de uma criada a seus pais em que pedia conselhos sobre como escapar ao assédio sexual de seu patrão. Foi a partir dela que surgiu a idéia para o romance.

De acordo com Keymer, o livro Familiar Letters apresenta diferentes tipos de cartas e variações sobre um mesmo tipo em que o autor faria sua escolha dependendo da reação que desejasse provocar no leitor, demonstrando, segundo sua visão, que Richardson estaria ciente da retórica epistolar e da duplicidade que a forma contém. ${ }^{104}$

Keymer vê o processo didático do autor de modo bastante complexo, pois para ele o didatismo de Richardson se baseia em um aprendizado dinâmico que tem por princípio o esforço e a cooperação ativa do leitor. Este método de instrução estaria de acordo com a concepção da participação ativa do aluno no aprendizado, exposta por Locke em seu livro Some Thoughts Concerning Education, aparentemente estudado por Richardson ao escrever a segunda parte de Pamela. ${ }^{105}$ Segundo a interpretação de Keymer, ao escrever sua obra, Richardson teria em mente um leitor atuante cujo esforço de raciocínio lhe permitiria apreender a mensagem subliminar do texto. Este, no entanto, é um leitor hipotético, pois dadas as diversas formas de pensar, o exercício do raciocínio leva cada um à sua própria

\footnotetext{
${ }^{102}$ Id., ibid., p. 19.

${ }^{103}$ KEYMER, 1992, p. 32.

${ }^{104}$ Id., ibid., p. 33.

${ }^{105}$ De acordo com as notas de Keymer. In: Id., ibid., p. 66.
} 
interpretação do texto, as mais distintas e conflitantes, e não a uma única interpretação, aquela desejada pelo autor. A partir deste ponto de vista, poderíamos dizer que Richardson se definiria como um autor de certa forma ingênuo, ou pelo menos, um orientador que se julgava capaz de induzir seu interlocutor à compreensão de sua mensagem e de seus ensinamentos.

De qualquer forma, preso a uma narrativa epistolar que não lhe proporciona uma orientação objetiva ou um julgamento isento, o leitor tem, ele próprio, que buscar dar sentido às complexidades e tensões do texto. Para Keymer é justamente desta forma que Richardson alcança seu objetivo didático. Ao pôr o leitor à prova, expondo-o a experiências e conflitos, e forçando-o a buscar o significado mais profundo, para além daquele que está na superfície, o autor obriga-o a compreender e julgar as suas próprias experiências de vida, reforçando sua capacidade de ponderar sobre si e sobre o mundo à sua volta para que se torne um indivíduo mais completo e apto a viver sua própria vida.

A partir da concepção de que a ambigüidade de sentido está implícita na forma epistolar, que oferece ao leitor a liberdade de fazer seus próprios julgamentos e interpretações, e de que em Pamela as apreensões do leitor se dão através da parcialidade de um narrador-protagonista, podemos concluir que a tarefa de leitura e absorção do significado de um romance como este é mais oblíqua. Entretanto, nem a forma epistolar, nem o narrador em primeira pessoa, possuem apenas desvantagens. As mesmas características que tornam esta leitura indireta também permitem ao leitor o acesso a uma investigação mais profunda do ser.

Tanto o narrador em primeira pessoa quanto a forma epistolar apresentam a grande vantagem de permitir que ambos, escritor e leitor, penetrem a vida interior das personagens explorando sua subjetividade. Através de um narrador-protagonista, o leitor tem acesso aos seus sentimentos e pensamentos mais íntimos. Pamela expressa seu sofrimento pela morte de sua senhora com grande ênfase, como podemos ver na frase a seguir:

“O how my eyes overflow! Don’t wonder to see the paper so blotted!"106

Da mesma maneira, ela busca persuadir todos à sua volta da intensidade de sua dor quando se vê de mãos atadas, prisioneira de Mr B., sem ao menos conseguir escapar da mansão de Lincolnshire:

\footnotetext{
${ }^{106}$ Pamela, carta I, p. 43.
} 
"And distress indeed! For here I am still! And every thing has been worse and worse! O the unhappy Pamela! Without any hope left, and ruined in all my contrivances!"107

Do mesmo modo como o narrador em primeira pessoa permite um mergulho na interioridade da personagem, assim também a forma epistolar, por seu estilo coloquial e natural, e seu caráter privado, é ideal para a investigação psicológica, pois permite ao autor delinear mais profunda e intensamente a operação das paixões em suas personagens. Estes dois fatores associados, a forma e o tipo de narrador, deram a Richardson a possibilidade de explorar um realismo psicológico sem precedente na prosa de ficção da época, identificandoo como uma espécie de precursor do monólogo interior e do fluxo de consciência que seriam explorados quase duzentos anos depois por Joyce e Woolf.

Boa parte da prosa de ficção do século XVIII buscava a identificação do leitor com o conteúdo da matéria lida, com o intuito de promover o desenvolvimento de seu padrão moral e sua sensibilidade.

Esta literatura sentimental ${ }^{108}$, da qual podemos dizer que o romance Pamela faz parte, se caracteriza como a expressão de uma fase intermediária entre o declínio da razão absoluta e o aparecimento da imaginação romântica, e seu aspecto mais evidente está na ênfase em demonstrar, de forma acurada, a resposta emocional das personagens em face dos acontecimentos que norteiam suas vidas. O termo sensibilidade, pouco usado antes do século XVIII, passou a qualificar “...the faculty of feeling, the capacity for extremely refined emotion and a quickness to display compassion for suffering.,"109

Baseada na teoria de Hume de que o que motiva a ação do homem são suas paixões e na compreensão de que seus aspectos físicos e morais não são características dissonantes, mas sim consonantes, a literatura sentimental constituía parte do treinamento moral e social dos indivíduos naquela época. Na metade do século XVIII, o fino trato era considerado resultado da combinação de traços mentais associados à delicadeza e à sensibilidade. Esta era vista sob uma ótica social, pois se entendia que a sensibilidade era o elemento que mantinha os indivíduos unidos em sociedade: o "homem de sentimento""110 era tido como um produto e um indicador da Sociedade Civil ${ }^{111}$.

\footnotetext{
${ }^{107}$ Pamela, diário, p. 209.

${ }^{108} \mathrm{O}$ termo "sentimental literature" foi extraído das páginas do livro: TODD, J. Sensibility: an Introduction. London, Methuen, 1986.

${ }^{109}$ TODD, J. Sensibility: an Introduction. London, Methuen, 1986. p. 7.

110 MANNING, S. "Sensibility". In: KEYMER, T. \& MEE, J., ed. The Cambridge Companion to English Literature: 1740 - 1830. Cambridge, Cambridge University, 2004. p. 83.

${ }^{111}$ Id., ibid., p. 83.
} 
Este homem de sentimento era um indivíduo que, devido a certo conforto material, tinha tempo para se dedicar ao cultivo e expressão das emoções em seus relacionamentos. Este modo de pensar estava de acordo com a função didática da literatura no século XVIII, que tinha como objetivo educar as paixões do homem de modo a caracterizar o grau apropriado de sensibilidade a ser demonstrada e de pintar o vício como indesejado e a virtude como um caminho a ser seguido.

A sensibilidade era vista como um instrumento de conhecimento da sociedade a partir da observação da natureza emocional dos indivíduos dentro da esfera doméstica em que homens e mulheres se definiam de acordo com a qualidade de suas respostas emocionais.

Na literatura, essa sensibilidade se manifestava na exacerbação das emoções e no uso de uma linguagem que pudesse transmitir em palavras a realidade dos sentimentos expressos e induzia o leitor a uma resposta emocional real. Assim cenas de dor, aflição e emoções intensas eram freqüentemente retratadas, sendo as grandes vítimas deste sofrimento mulheres indefesas, pessoas de idade e crianças que choravam copiosamente, se ajoelhavam diante de seus algozes e desmaiavam a todo instante. De acordo com Janet Todd,

"This fiction initially showed people how to behave, how to express themselves in friendship and how to respond decently to life's experiences. Later, it prided itself more on making its readers weep and in teaching them when and how much to weep. In addition, it delivered the great archetypal victims: the chaste suffering woman, happily rewarded in marriage or elevated into redemptive death..."112

De fato, esta literatura sentimental se valia de situações convencionais, personagens familiares e recursos de retórica para expressar sua mensagem e provocar uma reação nos leitores. Deste modo, um elemento importante utilizado pelos escritores é a linguagem que, através de substantivos como virtue e honesty, adjetivos como generous ou wicked $^{113}$ ou expressões como the best of husbands ${ }^{114}$, buscava uma empatia do leitor com a causa da personagem. Além disso, o uso excessivo de pontos de exclamação, parênteses e palavras grafadas em itálico altera o fluxo de leitura e chama a atenção do leitor para o momento exato em que a emoção deve ser sentida com mais força.

\footnotetext{
112 TODD, 1986, p. 4.

113 Os substantivos e adjetivos citados aparecem várias vezes ao longo de todo o romance; só para citar alguns exemplos: virtue aparece desde o título Pamela; or Virtue Rewarded - página de rosto da edição de 1801; honesty - página 62; generous - página 513; wicked - página 61 .

${ }^{114}$ Pamela, diário, p. 386.
} 
Historicamente falando, esta ênfase na sensibilidade pode ter suas raízes em uma nova constituição econômica da vida que começava a se delinear no século XVIII na Inglaterra. Janet Todd afirma que "At a time when the loose financial ties of early capitalism were emerging in the market-place, sentimentalism expressed a longing not only for domestic close-knit family but for a community firmly linked by sentiment and familial structures."

Além disso, com a saída do homem do ambiente familiar envolvido em atividades de comércio, a mulher tornou-se responsável por manter vivos dentro da família os valores religiosos de caridade e compaixão. Ademais, pensava-se que a mulher, por sua natural propensão ao choro e aos desmaios, expressava as emoções de modo mais sincero e espontâneo. Desta maneira, a consciência da mulher tornou-se predominantemente o local da sensibilidade. $^{116}$

Para tanto, uma literatura que desejasse explorar essa sensibilidade deveria investigar os meandros da mente feminina. Pamela, através de sua retórica, da escolha cuidadosa das palavras com que conta sua história e dos recursos da linguagem impressa, expõe com grande intensidade suas dúvidas e seus temores, esperando a empatia do leitor. O enfoque na sensibilidade, neste caso associada ao espaço privado próprio à contemplação, permite que, imediatamente após as cenas que vibram com forte emoção, mas que são rememoradas na proteção e tranqüilidade do closet, nossa narradora-protagonista relate em detalhe sua história, cena a cena, momento a momento.

Em Pamela observamos que a narração é quase simultânea à ação. Cada fato é praticamente descrito no momento em que ocorre, o que provoca no leitor a sensação de acompanhar os desdobramentos da história passo a passo, como se estivesse em meio à ação, graças à ênfase no espírito que as paixões suscitavam no momento em que eram sentidas e relatadas. A técnica narrativa definida por Richardson como writing to the moment ${ }^{117}$ além de aproximar o leitor da narração, imprime um ritmo mais dinâmico à história, pois à medida que os fatos se desenrolam, a personagem se refugia em seus aposentos privados para narrálos, deixando que a reflexão sobre eles seja feita pelo leitor. É o leitor quem preenche as lacunas da narrativa, os espaços em branco deixados pela urgência da narração. Uma narrativa a posteriori deveria contar com a memória, que teria certamente perdido as sensações e reflexões do instante em que uma situação crítica se desenvolve.

\footnotetext{
115 TODD, 1986, p. 16.

${ }^{116}$ MANNING, 2004, p. 67.

${ }^{117}$ MCKEON, 2002, p. 358.
} 
No romance, vemos que a capacidade da criada em exibir sensibilidade e virtude aumenta seu poder de atração sobre Mr B. e está muito além do que poderiam demonstrar as damas da alta sociedade. De fato, os jornais da época demonstravam uma elevação moral das virtudes do bem e da compaixão em contraste aos valores da inteligência e da sofisticação da mulher. ${ }^{118}$

Assim, as mulheres, por desenvolverem as emoções mais intensamente do que os homens, eram associadas de imediato à sensibilidade. Na visão de Todd, Richardson compartilha da idéia de que "...sensitive women, although socially subdued, became spiritually privileged and morally superior to lustful and less sensitive men."

Segundo a teoria de Locke de que o conhecimento advém das sensações, podemos dizer que as heroínas de Richardson expressam esse conhecimento através da sensibilidade e das sensações de seu corpo. Para elas, conhecer é sentir. Portanto, Mr B. se torna o homem ideal somente depois de se compadecer da sorte da jovem e ser capaz de se identificar com seu sofrimento.

Em seu estudo sobre a sensibilidade no romance do século XVIII, Van Sant associa a sensibilidade ao corpo e aos sentidos, colocando o coração como o centro da vida emocional e o cérebro como o centro da percepção no homem. Segundo ela, essas metáforas fisiológicas incitam a imaginação e aguçam o desejo de compreensão destes espaços psicológicos interiores. Assim como Todd, Van Sant também atribui um propósito moral ao apelo emocional da literatura que, através da empatia do leitor com o sofrimento da personagem, buscava instruí-lo quanto ao papel do afeto em sua vida social e privada. Desta forma, a sensibilidade deveria ser estimulada pelo escritor através da imaginação do leitor, buscando sua identificação com os estados de ânimo das personagens. Para Van Sant, "Scenes of suffering pierce the sensibility, causing pity and leading to sympathetic identification. At the same time the observable sensibility invites curiosity." $O$ que a leva a concluir que "Sensibility [is seen] as a central idea for understanding psychology." 120

Dentro desta perspectiva, o método utilizado por Richardson para conduzir sua investigação psicológica se baseia no isolamento e confinamento de suas heroínas, sendo que os sentimentos que advêm destas condições constituem o material a ser estudado por ambos, autor e leitor. O autor, por sua capacidade de criação de situações extremas, qualifica-se

\footnotetext{
${ }^{118}$ TODD, 1986, p. 19.

${ }^{119}$ Id., ibid., p. 80.

${ }^{120}$ VAN SANT, A. J. Eighteenth-Century Sensibility and the Novel: the Senses in Social Context. Cambridge, Cambridge University, 1993. p. 56.
} 
como um investigador, e o leitor, por sua capacidade de experimentar o sofrimento de forma vicária, qualifica-se como o observador de tal experiência.

Deste modo, através do uso da retórica corroborada pela grafia, da escolha da forma epistolar e da entrega da narração a uma narradora-protagonista, Richardson cria a impressão no leitor de que a experiência vivida na leitura é absorvida diretamente sem a presença de um mediador. Com o intuito de atingir seu objetivo moralizante, quanto mais real parecer a história, mais chance o autor tem, segundo este entendimento, de atingir o leitor no âmago de seu ser.

Para Patricia Spacks, a sensibilidade retratada e explorada no romance do século XVIII está associada à privacidade, não somente no sentido que comumente atribuímos ao termo, de isolamento físico ou afastamento do convívio social, mas a um outro tipo de privacidade: a privacidade psicológica. Esta se definiria como, “...the kind of privacy that entails self-protection of a sort not immediately visible to others." ${ }^{\prime 21}$ Para ela, o aprofundamento das complexidades emocionais do homem e a demonstração de sua sensibilidade estão associados à privacidade psicológica. Ao referir-se a Clarissa, Spacks a qualifica como "the privacy of the soul"122, que está além do controle social ou individual, e que, no século XVIII, era vista com certa desconfiança, dada a clara preocupação da sociedade com as aparências. Esta suspeita frente a uma privacidade em tese inviolável, também se manifesta em Pamela, e talvez explique a reação de Mr B. ao dizer a Mrs Jervis em tom de crítica:

"The girl is always scribbling!" 123

Embora não se caracterize como um tema no romance, a privacidade é responsável por criar uma atmosfera de reclusão e separação e, em última instância, de proteção, pois implica a geração de um espaço, fisicamente caracterizado como espaço doméstico e psicologicamente caracterizado como o espaço da mente, ao qual não se tem acesso a partir do exterior. Citando novamente Spacks, “The heroine's defense of her right to privacy - her locking of doors, her possessiveness about her correspondence - might be said to epitomize her insistence on her own spiritual integrity..."

\footnotetext{
${ }^{121}$ SPACKS, P. A. M. Privacy: Concealing the Eighteenth-Century Self. Chicago, University of Chicago, 2003. p. 7.

${ }^{122}$ Id., ibid., p. 17.

${ }^{123}$ Pamela, carta X, p. 54.

${ }^{124}$ SPACKS, 2003, pp. 223-224.
} 
Podemos dizer, portanto, que o romance do século XVIII ajudou a consolidar e explorar a idéia de uma vida interior que pode ser cultivada e que para tal precisa tanto da privacidade física quanto da psicológica, com todas as implicações sociais que esta descoberta viria a trazer. A privacidade psicológica confere ao homem a possibilidade de investigar seus sentimentos, daí a relação de interdependência que ela estabelece com a sensibilidade, na luta que travamos diariamente entre as premências da vida interior e as solicitações da vida em sociedade.

\subsection{Um embate no interior da mansão de Bedfordshire: carta XV}

Uma das cenas do romance que se desenrola nesta primeira mansão em Bedfordshire e que se destaca pela intensidade dos sentimentos expressos pelas personagens e por sua função crucial no desenvolvimento da narrativa é a carta de número $\mathrm{XV}$, em que a jovem descreve a cena na summer-house, e que será submetida a uma análise mais detalhada.

Como já foi dito anteriormente, o romance abre com a menção da criada à grande generosidade de Mr B. em permitir que ela permaneça na casa mesmo após ter perdido sua função de dama de companhia com a morte de sua senhora. A este relato se seguem outros nos quais Pamela expõe os favores e gentilezas de Mr B. ao presenteá-la com roupas e pertences da senhora. Estas primeiras cartas exaltam a graciosidade de modos e a aparência angelical de Mr B. e recheiam-se de elogios explícitos ou velados deste à beleza de Pamela. Algumas cartas mais tarde, no entanto, a atmosfera do romance assume características bastante distintas, após um encontro no jardim em que Mr B. rouba-lhe um beijo, deixando claro que seu interesse por ela vai muito além dos cuidados de um patrão pelo bem-estar de sua criada.

As verdadeiras intenções do patrão para com a jovem já são antecipadas pelo leitor mais atento que vê este interesse esboçar-se desde os primeiros toques de mãos, e, juntamente com Pamela, é alertado pelo pai da moça, que questiona a nobreza de coração de $\mathrm{Mr} \mathrm{B}$. Somente Pamela parece rejeitar essa idéia e, ao confrontar-se com ela, vê Mr B. revelar-se "in his true colours" 125 .

\footnotetext{
${ }^{125}$ Pamela, carta X, p. 54.
} 
A carta inicia já em meio à ação retomando as considerações da carta anterior, quando Pamela é interrompida por Mr B. em meio ao ato da escrita.

\section{"LETTER XV}

My dear Mother,

I broke off abruptly my last letter; for I feared he was coming; and so it happened. I put the letter into my bosom, and took up my work, which lay by me; but I had so little of the artful, as he called it, that I looked as confused, as if I had been doing some great harm." 126

Desde a abertura da carta, o leitor percebe o constrangimento de Pamela diante da presença de Mr B., e o receio de que ele a visse escrevendo aos pais a carta em que contava sobre o episódio no jardim e criticava explicitamente a atitude do patrão, que ela considera de todo reprovável. Ainda no primeiro parágrafo nota-se também seu tom sarcástico e ressentido no grifo em itálico da palavra "artful". Mrs Jervis, a governanta amiga e protetora, relata à jovem uma conversa que teve com Mr B. no dia anterior, em que ele a descreve como:

“...a subtle, artful little gypsey,...,"127

O grifo da palavra "artful" deixa claro o ressentimento e o desacordo de Pamela com a atitude de Mr B. em julgá-la ardilosa, capaz de criar situações falsas para beneficiar-se delas.

Se observarmos as outras palavras da carta grafadas em itálico pela própria Pamela, poderemos notar sua evidente discordância com a aparente opinião de $\mathrm{Mr}$ B. sobre ela e sobre a cena no jardim. No terceiro parágrafo, por exemplo, Pamela demonstra seu desacordo com a tentativa de Mr B. em diminuir o peso de seus atos, grifando em itálico as palavras "little kind" e "foolishly" em:

“' 'When I was a little kind to you,' said he, 'in the summer-house, and you behaved so foolishly upon it, as if I had intended to do you great harm..."128

De fato, a premência dos sentimentos de Pamela pode ser percebida em sua inteireza nas palavras com que ela lhe responde à pergunta "Have I done you any harm?"129, momentos depois de ter tido sua honra aviltada pela inesperada investida de Mr B.

\footnotetext{
${ }^{126}$ Pamela, carta XV, p. 61.

${ }^{127}$ Pamela, carta XIV, p. 60.

${ }^{128}$ Pamela, carta XV, p. 61.

${ }^{129}$ Pamela, carta XI, p. 55.
} 
“' 'Yes, sir,' said I, 'the greatest harm in the world: You have taught me to forget myself, and what belongs to me; and have lessened the distance that fortune has made between us..., ,130

Ou algumas frases antes quando ele lhe pergunta "Do you know whom you speak to?" A que Pamela lhe responde:

“' 'Yes, I do, sir, too well! Well may I forget that I am your servant, when you forget what belongs to a master.' ",131

Com estas palavras Pamela expõe sua angústia diante da afronta de $\mathrm{Mr} \mathrm{B}$. e demonstra firmeza de caráter incomum a uma criada, pois ao mesmo tempo em que curvar-se diante da vontade dele é inaceitável, enfrentá-lo também não é tarefa fácil. Ao assediá-la, $\mathrm{Mr}$ B. rompe com a distância social que os separa, e a obriga a agir fora dos padrões de comportamento esperados de uma criada, que incluía obediência total às decisões e vontades de seu patrão, sem questionar o porquê de seus atos, e a deferência que lhe era devida graças à sua condição social superior.

Ainda no parágrafo anterior, podemos notar o grande significado atribuído às palavras "forget" e "belong". A presença da idéia de "pertencer" é bastante reveladora do pensamento da época. Na concepção familiar do século XVIII em que todos, inclusive os empregados, faziam parte da família, o senhor sentia-se com poder de decisão sobre a vida, os interesses e as escolhas de seus criados. Portanto, nada é mais natural para Mr B. do que a idéia de obter os favores de Pamela como e quando melhor lhe aprouver.

Para McKeon, a obsessão de Mr B. pela criada está diretamente ligada à idéia aristocrática de posse. $\mathrm{Na}$ cena em que Mr B. entra no quarto da jovem em Lincolnshire e tenta possuí-la à força, ele a abraça, para que não fuja, e sob seu domínio afirma enfaticamente:

"I must say one word to you, Pamela: it is this; you now see, that you are in my power! You cannot get from me, nor help yourself..."132

McKeon destaca que uma recusa como a de Pamela, vinda de uma criada, é compreendida por $\mathrm{Mr}$ B. "...not only as insubordination but as a criminal act that gives Pamela the status of 'treasonable' 'rebel' against B.'s authority." 133 Este modo de

\footnotetext{
${ }^{130}$ Pamela, carta XI, p. 55.

${ }^{131}$ Pamela, carta XI, p. 55.

132 Pamela, diário, p. 242.

${ }^{133}$ MCKEON, 2002, p. 369.
} 
compreender os fatos está diretamente ligado à idéia de que os empregados eram vistos como propriedade do patrão e, portanto, recusas à sua vontade eram interpretadas como insubordinação. De fato, com sua recusa, e fazendo valer o seu lado de criada honesta, Pamela recebe a simpatia dos outros empregados e provoca uma disputa interna destes contra seu patrão, a ponto de Mr B. se ver forçado a dispensar os serviços de Mrs Jervis, $\mathrm{Mr}$ Longman e Mr Jonathan, criados estimados que eram parte de sua família havia muitos anos.

No entanto, se analisarmos mais a fundo, Pamela exerce um poder muito maior sobre Mr B., embora de outra natureza. Segundo McKeon, "Pamela's essential power is the passive and negative one of being virtuous, of resisting the sexual and social power of others." ${ }^{134}$ Seu poder e sua influência sobre Mr B. residem na sua nobreza de caráter, não uma nobreza herdada, mas uma nobreza desenvolvida e cultivada, que lhe permite falar a seu patrão de igual para igual. Esta "ousadia" de Pamela fica evidente quando ela lhe responde à pergunta "Do you know whom you speak to?" com as seguintes palavras:

"And he said, 'I'll do you no harm, Pamela; don't be afraid of me.' I said, 'I won't stay.' 'You won't, hussy! Do you know whom you speak to?' I lost all fear, and all respect, and said 'Yes, I do, sir, too well! Well may I forget that I am your servant, when you forget what belongs to a master.' "135

McKeon afirma ainda que "For Pamela, the conflict entails the struggle of a "free Person' against 'lawless Tyranny'."136 Para Pamela, sua função como criada a põe sob o domínio de Mr B., mas sua virtude e seu caráter são livres e devem manter-se desta forma, pois estas são qualidades que não são negociáveis, uma vez que constituem seu verdadeiro ser. Vendê-las ou entregá-las contra sua vontade seria tão abominável quanto insurgir contra sua própria vida. Esta indignação de Pamela diante da idéia de posse de Mr B. fica bastante clara na passagem em que Mrs Jewkes, temendo uma conspiração de Pamela, não permite que ela converse com os empregados. Pamela reage dizendo:

\footnotetext{
“ 'Are you afraid,' said I, 'that I should confederate with them to commit a robbery on my master?' 'Perhaps I am,' said the odious wretch; 'for to rob him of yourself, would be the worst robbery, in his opinion, that you could commit.' 'And pray,' said I, (as we walked on) 'how came I to be his property? What right has he in me, but such as a thief may plead to stolen goods?" ",137
}

\footnotetext{
${ }^{134}$ Id., ibid., p. 364.

${ }^{135}$ Pamela, carta XI, p. 55.

${ }^{136}$ MCKEON, 2002, p. 369.

${ }^{137}$ Pamela, diário, p. 163.
} 
Na mesma passagem, observamos que o conceito de "pertencer" aparece associado à idéia de "esquecer". Para se entregar a ele, Pamela deveria primeiro se esquecer de seus sentimentos, de sua condição social e dos ensinamentos recebidos de seus pais. Para ela, aceitar a corte de Mr B. significaria abandonar sua honra e honestidade, esquecer-se de sua criação religiosa e da obediência e respeito que deve aos pais. Possuidor de uma moral mais elástica, como nos é mostrado no romance, Mr B. desconhece estas atitudes e choca-se diante da recusa da criada em aceitar sua corte. É a partir de sua posição social e da condição privilegiada que esta lhe confere que ele tenta obter os favores da bela jovem, esquecendo-se da virtude primordial de um patrão, que é a de zelar pelo bem-estar de seus criados.

Ainda na carta de número XV, no parágrafo 4, as palavras "hardly" e "argument" em itálico mostram a desaprovação de Pamela diante da indignação de $\mathrm{Mr}$ B. ao saber que o episódio foi revelado a Mrs. Jervis e aos pais da moça.

"He interrupted me, 'Hardly! you little equivocator! what do you mean by hardly? Let me ask you, Have you not told Mrs Jervis for one?' 'Pray your honour,' said I, all in agitation, 'let me go down; for it is not for me to hold an argument with your honour.' 'Equivocator, again!' and took my hand, 'why do you talk of an argument? Is it holding an argument with me, to answer a plain question?"138

Como não poderia deixar de ser, ele a acusa de tomar liberdades com seu nome, desconsiderando a reputação de ambos, ao falar abertamente sobre o acontecido à governanta e aos seus pais; enquanto que para Pamela

“...to keep a secret of such nature, [...] might encourage him to think I did not resent it as I ought, and would keep worse secrets, and so make him do worse by me."139

Quando Mr B. insiste sobre o fato de Pamela ter contrariado suas ordens relatando o acontecido a Mrs. Jervis, a jovem reage dizendo:

“ 'Then, sir,' said I, 'why should your honour be so angry I should tell Mrs Jervis, or any body else, what passed, if you intended no harm?'

Esta frase chama a atenção pelo contraste entre a forma de tratamento usada por Pamela ao reportar-se a Mr B. e a atitude expressa em suas palavras. Nas formas de tratamento "your honour" ou "sir", estão contidos um respeito e uma admiração que contradizem a afronta de sua frase. Nota-se, portanto, que o respeito que ela lhe deve como

\footnotetext{
${ }^{138}$ Pamela, carta XV, p. 61.

${ }^{139}$ Pamela, carta XII, p. 57.

${ }^{140}$ Pamela, carta XV, p. 62.
} 
criada está contido na forma de tratamento, ou quando, ao longo de todo o romance, ela se refere a ele como "my master". No entanto, ao defender sua honra, ela assume sua condição de mulher e é a partir dessa posição que ela lhe fala nos momentos em que sua virtude é ameaçada e sua honestidade, posta em dúvida. Tal atitude é compatível com a lição aprendida de seus pais:

“...to value honesty above my life."

E está em concordância com a frase anterior a essa no romance, na qual Pamela afirma não ter nada mais em que confiar a não ser em "her virtue and good name"142, denotando o grande peso atribuído na época à pureza e à reputação de uma moça e demonstrando que qualquer possibilidade de um casamento bem sucedido, e com ele a garantia de uma vida tranqüila, dependia de fatores morais, sociais e econômicos.

Estas, contudo, eram qualidades esperadas de uma moça de boa família, não de uma criada, para quem a obediência deveria estar acima de tudo, inclusive da honra e da virtude. Pamela, no entanto, preocupa-se com sua honra e a retidão de seu caráter, como podemos ver novamente no trecho a seguir:

" 'For heaven's sake, your honour, pity a poor creature, that knows nothing, but to cherish her virtue and good name: I have nothing else to trust to;' "'143

Ao atribuir qualidades de dama a uma criada e colocar uma personagem de extrato social baixo no centro da ação dramática, Richardson rompe com as convenções sociais e literárias, e exalta os ideais de uma classe social que surgia com mais força no início do século XVIII: a burguesia.

O século XVIII foi um século marcado por grandes acontecimentos históricos que trouxeram mudanças profundas no modo de vida europeu. $\mathrm{O}$ grande acontecimento do final do século, a Revolução Francesa de 1789, foi na verdade o apogeu de uma série de mudanças sociais e econômicas que tiveram início quando, ainda na segunda metade da Idade Média, os primeiros representantes das classes médias apareceram no cenário político, econômico, social e literário graças à circulação de dinheiro e ao aumento do comércio trazidos pelas guerras e pelas Cruzadas.

\footnotetext{
${ }^{141}$ Pamela, carta XV, p. 62-63.

${ }^{142}$ Pamela, carta XV, p. 62.

${ }^{143}$ Pamela, carta XV, p. 62.
} 
Mais tarde, no século XVII, a acumulação de capital permitiu que representantes da classe média inglesa se unissem a membros da gentry ${ }^{144}$ ou da aristocracia através de casamentos e da aquisição de terras que os aristocratas se viam forçados a vender devido às altas taxas e impostos. Muitos ricos mercadores adquiriram enormes propriedades de modo a aumentar seu prestígio e aproximar seus filhos dos aristocratas. Alguns dos membros da classe média, que se haviam unido às classes mais abastadas, copiavam seu modo extravagante de viver. Contudo, a maior parte dos integrantes da classe média do século XVII, vivia uma vida mais simples, mais modesta, mais reservada e de maior respeito, ligada aos valores morais do Puritanismo. Idéias que iriam se cristalizar no romance do século XVIII, mas que já fermentavam naquela época, antecipando os novos valores de um novo modo de vida.

A expansão das classes médias deu-se, principalmente, graças às mudanças sociais e econômicas trazidas pela Revolução Industrial e Agrícola na primeira metade do século XVIII, e que iria alterar completamente o panorama da vida na Inglaterra no final do século. O desenvolvimento das primeiras indústrias e do maquinário que iria movimentá-las veio em conseqüência à estimulação do comércio e da nova produção tecnológica.

A Revolução Agrícola, por sua vez, foi possível graças ao movimento das enclosures e às melhorias implementadas à criação de gado e ao modo de produção nas fazendas. A Revolução Industrial e Agrícola trouxe à Inglaterra um grande avanço tecnológico em relação às outras nações européias e tornou possível a acumulação de riquezas, apesar do alto preço a ser pago pelas populações menos abastadas. A nação viu-se dividida em duas grandes classes sociais: os proprietários de indústrias e fazendas e aqueles que viviam de seus salários, aumentando a distância entre os pobres e ricos e aproximando as classes mais favorecidas: a aristocracia, a gentry e a classe média.

No âmbito do pensamento, o Renascimento também trouxe profundas mudanças no modo de vida inglês. O Renascimento na Inglaterra teve seu início em 1509, com a subida de Henrique VIII ao trono e, apesar de ter sido grandemente influenciado pela Itália, teve suas características tipicamente inglesas, numa tentativa de romper com a forte identificação do movimento com Roma e o Papa.

\footnotetext{
${ }^{144}$ Esta classe social já fazia parte da sociedade inglesa do século XVI. Os membros da gentry eram homens bem-nascidos e com renda própria que, no entanto, não obtinham seus ganhos através de uma profissão rentável, nem possuíam os títulos da aristocracia inglesa. Eles se engajavam principalmente em funções públicas, como magistrados, membros do Parlamento, ou em um dos muitos comitês locais.
} 
Em contraste ao caráter pagão da arte na Itália, na Inglaterra o movimento demonstrou uma forte influencia religiosa dos ideais protestantes e principalmente Puritanos. O ensino humanista adotado nas Grammar Schools e nas universidades de Oxford e Cambridge se baseava no poder da razão para interpretar e compreender o homem e a natureza, e atribuía às artes, em especial à literatura, o valor de instrumento da razão. Esta nova atitude científica encorajou a autoconfiança e a crença no progresso do homem, liberando sua mente do medo infundado, da superstição e da ignorância. Foi neste período que as características do inglês típico começaram a se delinear: uma visão de mundo prática e materialista associada ao uso do bom senso e da razão.

A sociedade inglesa do século XVIII valorizava o individualismo, valendo-se de oportunidades para o empreendimento e o enriquecimento. Mais e mais pessoas buscavam o entretenimento e a realização pessoal e, para os homens das classes mais abastadas, o prazer sexual estava dissociado do pecado e da vergonha. Contudo, havia grande ênfase sobre o comportamento correto a ser adotado em sociedade, e a sociabilidade, a educação e a arte da conversação eram fatores de extrema valia para a sociedade da época.

Apesar dos diferentes gêneros presentes na literatura da primeira metade do século XVIII na Inglaterra, a prosa foi o gênero que mais sofreu a influência das classes médias, que encontraram nos romances e jornais um modo de expressar sua voz. O baixo custo dos jornais e o uso das bibliotecas circulantes foram fatores que contribuíram para o desenvolvimento da leitura entre os membros da burguesia.

Dentro desta perspectiva, é importante observar que o gênero 'romance' surgiu a partir de uma drástica mudança social, econômica e filosófica que teve sua expressão maior no século XVIII, mas que de fato teve início muito antes, ainda na passagem da Idade Média para o Renascimento. Essa visão de mundo mais realista, mais centrada na razão teria trazido como conseqüência o desejo de ver esta mesma realidade retratada nas artes plásticas e na literatura.

No âmbito do desenvolvimento da vida do homem podemos afirmar que o romance teria surgido em resposta aos anseios de uma classe social nova, a burguesia, que ao definir seu lugar numa nova estrutura de mundo faria uso de diversos meios para expressar seus ideais e desejos. 
Esta idéia está presente em Lukács, que afirma em sua introdução a $O$ Romance como Epopéia Burguesa:

"Embora nas literaturas do antigo Oriente, da Antigüidade e da Idade Média existam obras, sob muitos aspectos, semelhantes ao romance, este só adquire seus caracteres típicos na sociedade burguesa. Todas as contradições específicas desta sociedade, bem como os aspectos específicos da arte burguesa, encontram sua expressão mais plena justamente no romance. Ao contrário de outras formas de arte (o drama, por exemplo), que a literatura burguesa assimila e remodela segundo seus próprios interesses, as formas narrativas da literatura antiga sofreram, no romance, mudanças tão profundas que se pode falar aqui de uma forma artística substancialmente nova.,"145

Na definição do romance como 'epopéia burguesa' está clara a identificação do gênero com as classes médias emergentes.

Ainda segundo Lukács, a grande descoberta dos primeiros romancistas do século XVIII foi perceberem que o verdadeiro material do romance estava na representação da vida privada. No entanto, a vida privada não se torna uma representação banal da história de um indivíduo, pois o que temos de fato no romance é a representação das grandes forças históricas da sociedade burguesa manifestadas no fenômeno individual.

Neste contexto, nos interessa o estudo das razões sociais e históricas que levaram a burguesia a desenvolver sua vida em sociedade de maneira distinta de como se vinha fazendo, modificando os valores existentes que serviam de referência às classes mais abastadas.

Ao caracterizar nossa narradora-protagonista como uma criada com qualidades de dama da alta sociedade, podemos dizer que Richardson faz uma veemente defesa das possibilidades de ascensão pessoal e social dos representantes de uma classe média emergente. No entanto, Pamela possui qualidades que estão além daquelas das classes mais elevadas. Sua virtude e retidão de caráter são conceitos que devem ser absorvidos na vida pouco moderada de uma aristocracia de valores morais menos rigorosos. Pode-se dizer que o romance faz uma apologia à união destas duas classes sociais: da culta e bem-nascida aristocracia à reta e virtuosa classe média emergente. Contudo, não sem que antes haja o aprimoramento de ambas as classes. A aristocracia deve aperfeiçoar-se através de uma vida mais comedida e de valores morais mais acentuados e a classe média, através da elevação social e do aprimoramento do gosto e da apreciação das artes. Após tal elevação, estas duas

${ }^{145}$ LUKÁCS, G. "O Romance como Epopéia Burguesa". Revista Ensaios Ad Hominem. São Paulo, n.1, t.II, 1999. p. 87. 
classes sociais unidas representariam uma força quase que imbatível no redirecionamento dos rumos que assumiria a sociedade da época.

Literariamente, esta união se dá através do casamento entre a criada e seu patrão. Ela, uma jovem de beleza refinada que chegou à casa dos senhores com os valores morais já inculcados por seus pais, mas que recebeu o devido aprimoramento nos modos, no gosto e nas artes. Ele, o aristocrata bem-nascido que troca a lascívia pelo amor à criada de exemplar caráter.

Em termos espaciais, observamos ainda nesta primeira mansão que, além de possuir seu próprio quarto, Pamela, por sua função de dama de companhia, tem acesso irrestrito ao closet da senhora, e após sua morte continua a fazer uso dos aposentos para sua correspondência. Numa época em que na Inglaterra as casas das famílias de menos posses eram superlotadas, o fato de Pamela, uma representante da pequena burguesia inglesa, ter seu próprio closet e poder se refugiar nele para repensar o mundo é algo que parece bastante revelador dos anseios da nova sociedade burguesa.

Neste ponto podemos fazer uma referência à pequena casa dos pais de Pamela, em contraste à opulência e amplidão das mansões da narrativa. O pouco que se sabe sobre ela é que se localiza além do mercado, a dez milhas da mansão de Bedfordshire e a viagem a pé de uma casa a outra dura uma noite. Além disso, sabemos que não há sequer um quarto adequado para Pamela, pois em carta aos pais ela diz:

"And now, my dearest father and mother, expect soon to see your poor daughter, with an humble and dutiful mind, returned to you: And don't fear, but I know how to be as happy with you as ever: For I will lie in the loft, as I used to do; and pray let my little bed be got ready;",146

A partir deste breve relato, podemos inferir a distância social que separa as duas famílias. Da mesma forma como no relacionamento entre os jovens deve haver uma mudança mútua, em que ambos caminham um na direção do outro para juntos poderem ascender social ou moralmente, o mesmo se pode notar no relacionamento entre as famílias. A família de Pamela, de valores morais elevados, ascende socialmente com a ajuda de Mr B., e a família de Mr B., representada após a morte da mãe por sua única irmã, também deve passar pela reforma moral por que passa Mr B. Esta elevação, portanto, não se restringe às personagens, mas engloba também suas famílias, demonstrando que esta reforma é parte de um processo social amplo e profundo que exige a reestruturação de ambas as classes.

\footnotetext{
${ }^{146}$ Pamela, carta XVI, p. 68.
} 
Voltando à carta em que as personagens discutem suas diferentes reações à cena que se desenrola na summer-house, diante da afronta de Pamela, Mr B. reage violentamente, batendo o pé e chamando-a de "insolent", lembrando-lhe "...to whom [she] was talking."147 Pamela, que segundo Mr B. "...has all the arts of her sex" ${ }^{\text {"148, }}$, reage ao comportamento impetuoso de Mr B., ajoelhando-se, chorando e pedindo clemência, e afirma que jamais desejaria ser insolente ou desobediente, se as ordens de Mr B. não fossem

"...contrary to that first duty [to cherish her virtue and good name], which shall ever be the principle of my life!"149

Além da retidão de caráter, Pamela ainda demonstra ter outras qualidades, apesar da pouca idade. No trecho a seguir seu pai exalta sua prudência e bom senso, o que, no entanto, não o impede de temer pela integridade moral da filha:

"For though you are blessed with sense and prudence above your years, yet I tremble to
think, what a sad hazard a poor maiden, of little more than fifteen years of age, stands
against the temptations of this world, and a designing young gentleman, if he should
prove so, who has so much power to oblige, and has a kind of authority to command as
your master."150

Por este trecho da carta do pai de Pamela vemos expressa em suas palavras a autoridade de comando de Mr B. sobre os desejos e desígnios da jovem. Tendo sido a carta escrita pelo pai de Pamela, o leitor fica sem saber se o grifo em itálico das palavras "power" e "authority" foi originalmente inserido por ele, ou se foi de Pamela, ao transcrevê-la. De qualquer modo, estas palavras reiteram o poder de $\mathrm{Mr}$ B. sobre as decisões e escolhas de seus empregados, conferido a ele por sua posição de master. E literariamente nos demonstra mais uma vez o domínio da narradora sobre a narração.

Apesar de todos os temores do pai, ela afirma, talvez como mais um recurso de sua retórica, não estar submetida a esta condição de vida artificial, muito acima da situação de sua família:

“...for although I have lived above myself for some time past, yet I can be content with rags and poverty, and bread and water..."

\footnotetext{
${ }^{147}$ Pamela, carta XV, p. 62.

${ }^{148}$ Pamela, carta XVI, p. 67.

${ }^{149}$ Pamela, carta XV, p. 63.

${ }^{150}$ Pamela, carta VIII, p. 52.

${ }^{151}$ Pamela, carta III, p. 47.
} 
O diálogo que se segue apresenta um Mr B. impiedoso, sarcástico e determinado, disposto a assumir a condenação de seus atos quando, ao atingir seu objetivo, vier a merecer tal julgamento. Pamela, contrariamente, recorre à proteção divina e jura preferir a morte à desonra. Aqui, novamente, a cena revela mais uma das qualidades de Pamela: a de moça culta e instruída.

"O how I was terrified! I said, like as I had read in a book a night or two before,' 'Angels and saints, and all the host of heaven, defend me! And may I never survive one moment, that fatal one in which I shall forfeit my innocence!' 'Pretty fool!' said he, 'how will you forfeit your innocence, if you are obliged to yield to a force you cannot withstand? Be easy, for let the worst happen that can, you'll have the merit, and $I$ the blame; and it will be a good subject for letters to your father and mother, and a pretty tale moreover for Mrs Jervis.' He then, though I struggled against him, kissed me, and said, 'Who ever blamed Lucretia? The shame lay on the ravisher only: and I am content to take all the blame upon myself; as I have already borne too great a share for what I have deserved.' 'May I,' said I, 'Lucretia like, justify myself by my death, if I am used barbarously?' 'O my good girl!' replied he, tauntingly, 'you are well read, I see; and we shall make out between us, before we have done, a pretty story for a romance.' ",152

Ao citar Hamlet, embora não com as palavras exatas, e ao responder à menção de Lucrecia por Mr B., Pamela demonstra seu preparo e instrução, colocando-se, neste aspecto, em posição de igualdade com ele. Novamente Richardson rompe com as tradições criando uma criada culta e instruída, filha de um professor que teve que abandonar sua profissão e trabalhar como empregado de uma fazenda para sustentar a família e pagar as dívidas contraídas ao tentar, sem sucesso, montar sua própria escola. Como nos diz Pamela,

"...you, my father, who are so well able to teach, and write so good a hand, succeeded no better in the school you attempted to set up; but was forced to go to such hard labour." 153

Finalmente, considerando-se as contradições e tensões no caráter de Pamela e em seu relacionamento com Mr B., a jovem escolhe resistir às investidas de seu patrão e diante da ameaça explícita de possuí-la a qualquer custo, a criada, com coragem redobrada, foge, tranca-se no quarto ao lado e desmaia, como último recurso de uma mulher cuja honra é ameaçada.

"He then offered to kiss my neck. Indignation gave double strength, and I got from him by a sudden spring, and ran out of the room; and the door of the next chamber being open, I rushed into it, and threw-to the door, and it locked after me; but he followed me so close, he got hold of my gown, and tore a piece off, which hung without the door;

\footnotetext{
${ }^{152}$ Pamela, carta XV, p. 63.
}

${ }^{153}$ Pamela, carta V, p. 48. 
for the key was on the inside. I just remember I got into the room. I knew nothing further till afterwards, having fallen down in a fit; and there I lay, till he, as I suppose, looking through the key-hole, 'spied me upon the floor, and then he called Mrs Jervis, who, by his assistance, bursting open the door, he went away, seeing me coming to myself; and bid her say nothing of the matter, if she were wise." 154

Mr B., privado da possibilidade de ação, chama a governanta para que cuide da jovem, mas não sem antes instruí-la quanto ao encontro que deseja ter com Pamela no dia seguinte nos aposentos de sua mãe.

\begin{abstract}
“' 'O, sir,' said she, 'for your honour's sake, and for Christ's sake -' But he would not hear her, and said, 'For your own sake, I tell you, Mrs Jervis, say not a word more. I have done her no harm. And I will not have her stay in my house; prating, perverse fool, as she is! But since she is so apt to fall into fits, or at least to pretend to do so, prepare her to see me to-morrow after dinner, in my mother's closet, and do you be with her as a witness to what shall pass between us.' And so he went out in a passion, and ordered his chariot to be got ready, and went a visiting somewhere."155
\end{abstract}

Deste modo termina o relato deste embate entre Pamela e Mr. B., que se desdobrará em muitos outros acontecimentos no romance, e que revela as características centrais que caracterizam o conflito na obra.

\title{
2.6. A caracterização das personagens: Pamela e Mr B.
}

Sendo a narradora-protagonista de sua própria história, Pamela é também a personagem central em torno da qual gira o conflito do romance. Dentre as inúmeras qualidades já citadas, a beleza e o refinamento de Pamela, por exemplo, parecem ser seus grandes atributos e, por que não dizer, seu grande trunfo na ascensão a uma nova vida. Além disso, sua descrição psicológica apresenta ao leitor uma jovem temente a Deus, segundo a moral puritana.

Várias vezes no romance ela recorre à proteção divina e é sua fé em Deus que a demove da idéia de pôr fim a seu sofrimento lançando-se ao lago:

"....and I thought, What art thou about to do, wretched Pamela? How knowest thou, though the prospect be all dark to thy short-sighted eye, what God may do for thee, even when all human means fail?"

\footnotetext{
${ }^{154}$ Pamela, carta XV, p. 63-64.

${ }^{155}$ Pamela, carta XV, p. 64.

${ }^{156}$ Pamela, diário, p. 212.
} 
Mais tarde no romance, sua crença no poder divino é recompensada quando ela, após o pedido de casamento de Mr B., reconhece que somente Deus tem o poder de transformar em alegria o que antes era sofrimento:

"He [Mr B.] raised me, and as I bent towards the door, led me to the stairs foot, and saluting me there again, left me to go up to my closet, where I threw myself on my knees, and blessed that gracious God, who had thus changed my distress to happiness, and so abundantly rewarded me for all the sufferings I had passed through."157

Este entendimento de Deus está em concordância com o conceito puritano da recompensa divina. A fé puritana acredita que todo aquele que se dedica somente a Deus e ao trabalho, sem desviar sua atenção para os atrativos da vida mundana, deve receber como recompensa o devido conforto material. Em Pamela, nossa heroína recebe como recompensa à sua virtude moral e à sua entrega a Deus a ascensão social a um nível de vida muito superior à sua condição inicial de criada, e o conforto material que lhe garantirá um futuro tranqüilo mesmo em face da morte de $\mathrm{Mr}$ B., como fica claro na seguinte passagem do romance:

"I have, therefore, as human life is uncertain, made such a disposition of my affairs, as will render you absolutely independent; as will secure to you the means of doing a great deal of good..."158

Ao final do romance, o leitor se vê diante de uma Pamela madura, confiante e consciente de sua posição social. Seu desejo em fazer o bem está claro desde o início, quando ela diz ser esta a única razão para invejar os ricos:

"O how amiable a thing is doing good! it is all I envy great folks for!" 159

Mais tarde, já casada, ela se mostra determinada a ajudar os menos favorecidos do mesmo modo como ela foi agraciada por Deus.

"Great and good God! as thou hast enlarged my opportunities, enlarge also my will, and make me delight in dispensing to others a portion of that happiness which I have myself so plentifully received at the hands of thy gracious Providence! [...] This, as I conceive, is the indispensable duty of a high condition; [...] the exalted pleasure that flows from the reflection of having had it put into one's power to administer comfort and relief to those who stand in need of it. A pleasure which of itself infinitely rewards the beneficent mind, were there to be no after account at all!" 160

\footnotetext{
${ }^{157}$ Pamela, diário, pp. 311-312.

${ }^{158}$ Pamela, diário, p. 510.

${ }^{159}$ Pamela, carta VI, p. 50.

${ }^{160}$ Pamela, diário, pp. 388-389.
} 
Apesar de já ter todas as suas qualidades delineadas desde o início do romance, sua confiança incondicional na bondade divina a presenteia com uma condição social favorável que lhe dá a chance de fazer bom uso de suas virtudes.

Pamela, portanto, não é uma jovem qualquer. Nossa narradora-protagonista, mesmo que a partir de um ponto de vista ambíguo e comprometido, se mostra ao leitor como uma criada especial, cujos atributos de beleza, instrução, sensatez, persuasão e esperteza fazem dela uma mulher à altura de um marido como Mr B.: um membro do Parlamento inglês, um futuro Lorde, dono de inúmeras propriedades na Inglaterra, belo e de fino trato, como o descreve Mrs Jewkes:

“...the handsomest and finest young gentleman in five counties..."161

A própria Pamela o descreve como:

“...he is a tall, and very majestic man." 162

Além disso, um ótimo partido, segundo Mrs Jervis, a governanta:

“....a fine gentleman; he has a great deal of wit and sense, and is admired, as I know, by half a dozen ladies, who would think themselves happy in his addresses. He has a noble estate;",163

Quanto à sua descrição psicológica, Mr B. é um perfeito representante da aristocracia, pois, como fica claro ao longo do romance, ele espera que sua vontade seja obedecida prontamente e sem questionamentos. O orgulho é o que move a ação deste aristocrata inglês e um pedido seu não atendido provoca nele ataques de fúria. Seu desejo por Pamela o faz tomar atitudes impensadas, como entrar sorrateiramente em seu quarto em Bedfordshire e novamente em Lincolnshire para tentar possuí-la a qualquer custo. Estas características de $\mathrm{Mr}$ B. estão de acordo com a descrição que ele mesmo faz do caráter das pessoas bem nascidas:

\footnotetext{
${ }^{161}$ Pamela, diário, p. 145.

${ }^{162}$ Pamela, diário, p. 248.

${ }^{163}$ Pamela, carta XIX, p. 72.
} 
"We people of fortune, or such as are born to large expectations, of both sexes, are generally educated wrong. [...] We are usually headstrong in our wills, and being unaccustomed to controul from our parents, know not how to bear it. Humoured by our nurses, through the fault of our parents, we practice first upon them; and shew the gratitude of our dispositions, in an insolence that ought first to have been checked and restrained. Next, we are to be favoured and indulged at school; and we take care to reward our masters for their required indulgences, with further grateful instances of our unruly dispositions. After our wise parents have bribed our way through the usual forms, with very little improvement in our learning, we are brought home; and then our parents take their deserved turn. We torture their hearts by our undutiful behaviour; which, however ungrateful in us, is but the natural consequence of their culpable indulgence, from infancy upwards." $" 164$

Seus sentimentos com relação a Pamela começam a adquirir outro aspecto após sua leitura do diário da jovem e depois de tomar conhecimento da urgência de seu sofrimento descrito no episódio do lago. Ainda assim, mesmo após a resolução de Mr B. em mudar sua atitude, Pamela teme que

“...his pride of heart, and pride of condition, may again take place;",165

Esta mudança na atitude de $\mathrm{Mr} \mathrm{B}$. parte inicialmente da leitura dos relatos da jovem em seu diário, mas ela é também fruto de uma reflexão sobre a origem de sua nobreza, uma nobreza herdada que se coloca em contraposição à nobreza de caráter de Pamela, uma nobreza cultivada ao longo da vida. Como o próprio Mr. B admite, ao final do romance, foram as qualidades morais de Pamela que verdadeiramente o conquistaram:

“ 'My dear friend,' answered my delighted master, 'I told you before, that her fine person made me a lover; but it was her mind, that made me an husband." ",166

Esta questão sobre a nobreza de caráter de Pamela é discutida por McKeon, que a caracteriza como sendo "[a] case ...of "true nobility" "167 Para ele esta verdadeira nobreza de caráter é o que avaliza a mobilidade social da criada dentro da obra. Em suas próprias palavras, "For the message that inherited social status is strictly 'accidental' and strictly uncorrelated with the 'natural' gifts of virtue and merit is central [...] to the ideology of Pamela..."168 Assim sendo, a nobreza de caráter é retratada no romance como a verdadeira

\footnotetext{
${ }^{164}$ Pamela, diário, p. 463.

165 Pamela, diário, p. 287.

${ }^{166}$ Pamela, diário, p. 493.

${ }^{167}$ MCKEON, 2002, p. 365.

${ }^{168}$ Id., ibid., p. 365.
} 
nobreza, aquela que deve ser almejada e cultivada, ao passo que um título recebido por herança familiar não possui valor moral algum, podendo, ao contrário, servir como forma de coação para a realização dos próprios desejos em detrimento da vontade dos outros. $\mathrm{Na}$ personagem de Mr B. vemos ilustrada a manipulação e coerção que as classes mais abastadas buscam exercer sobre os demais, pois se relacionam com todos a partir de sua posição social mais elevada.

Da mesma forma que Pamela se desenvolve e amadurece ao longo da obra, assim também Mr B. se transforma e reforma seu caráter, evoluindo ao longo do romance. Estamos diante de duas personagens que podem ser chamadas de "esféricas", segundo a classificação de Forster. ${ }^{169}$

Antonio Candido, no livro A Personagem de Ficção, define as personagens esféricas como sendo aquelas cujas “...características se reduzem essencialmente ao fato de terem três e não duas dimensões; de serem, portanto, organizadas com maior complexidade e, em consequiência, capazes de nos surpreender." ${ }^{170}$ Segundo esta definição, podemos afirmar que tanto Pamela quanto Mr B. refletem, amadurecem e surpreendem o leitor ao longo do romance. Pamela se torna a criada que, pela força de seu caráter, é recompensada com uma situação social muito acima de sua condição inicial e Mr B. é o aristocrata bem-nascido que, apesar do orgulho de seu caráter e de sua posição, abre-se a um novo modo de vida e é recompensado com uma mulher que tem todas as qualidades necessárias para fazê-lo feliz e para educar seus futuros filhos.

A questão da caracterização da personagem é uma questão central no romance. Para Anatol Rosenfeld, dentre as características que formam o gênero narrativo, a personagem é de vital importância. A seu ver, "Como indicadora mais manifesta da ficção é por isso bem mais marcante a função da personagem na literatura narrativa (épica). [...] É geralmente com o surgir de um ser humano que se declara o caráter fictício (ou não fictício) do texto..."

No entanto, embora a função da personagem seja central no romance, ela não pode ser compreendida em separado, mas somente na relação com os outros elementos que compõem a narrativa. Para Candido,

\footnotetext{
${ }^{169}$ A classificação elaborada por Forster foi extraída do texto "A Personagem do Romance" de autoria de Antonio Candido. In: ANTONIO CANDIDO et al. A Personagem de Ficção. 10ed. São Paulo, Perspectiva, 2004. pp. 62-63.

${ }^{170}$ Id., ibid., p. 63.

${ }^{171}$ ROSENFELD, A. "Literatura e Personagem". In: ANTONIO CANDIDO, 2004, p. 23.
} 
"Não espanta, portanto, que a personagem pareça o que há de mais vivo no romance; e que a leitura deste dependa basicamente da aceitação da verdade da personagem por parte do leitor. [...] Isto nos leva ao erro, freqüentemente repetido em crítica, de pensar que o essencial do romance é a personagem, - como se esta pudesse existir separada das outras realidades que encarna, que ela vive, que lhe dão vida. Feita esta ressalva, todavia, pode-se dizer que é o elemento mais atuante, mais comunicativo da arte novelística moderna, como se configurou nos séculos XVIII, XIX e começo do XX; mas que só adquire pleno significado no contexto, e que, portanto, no fim de contas a construção estrutural é o maior responsável pela força e eficácia de um romance.”172

Nossas personagens, portanto, crescem e amadurecem ao longo do romance. Porém, este amadurecimento somente se dá a partir do momento em que as personagens saem de seu ambiente inicial e são removidas para um novo espaço. Assim sendo, a partir da saída de Bedfordshire, a narrativa muda completamente de rumo com o rapto de Pamela por Mr. B. e seu estabelecimento como uma espécie de prisioneira na mansão de Lincolnshire.

\subsection{A caracterização do espaço: a mansão de Lincolnshire}

Esta grandiosa residência é apenas mais uma das inúmeras propriedades de Mr B., localizada no condado de Lincolnshire, nas proximidades do vilarejo de Stamford ${ }^{173}$. Espacialmente ela se localiza mais distante do centro, Londres, e, portanto, torna-se mais adequada às intenções pouco elevadas do jovem. A falta de descrições dos detalhes desta casa de campo nos leva a concluir que seu interior oferece um ambiente de menos luxo e suntuosidade do que a grandiosa moradia do início do romance, embora a descrição que Pamela faz dela à sua chegada a qualifique como uma bela e antiga mansão de aparência solitária, alcançada pelo viajante por uma alameda de imponentes elmos:

"About eight at night we entered the court-yard of this handsome, large, old, lonely mansion, that looked to me then, with all its brown nodding horrors of lofty elms and pines about it, as if built for solitude and mischief.",174

A apresentação que temos da casa está de acordo com o sentimento de opressão, horror e solidão pelo qual passa a protagonista, uma vez que acabou de se saber raptada e levada a um ambiente ermo e inóspito. As altas e majestosas árvores à entrada conferem um ar sombrio e melancólico à casa e certamente uma impressão pouco encorajadora ao viajante

\footnotetext{
172 ANTONIO CANDIDO. “A Personagem do Romance”. In: ANTONIO CANDIDO, 2004, pp. 54-55.

${ }^{173}$ Pamela, diário, p. 236.

${ }^{174}$ Pamela, diário, p. 146.
} 
que se aproxima. Além disso, neste ambiente Pamela não encontrará o apoio e a generosidade dos empregados, como era o caso dos amigos com quem se relacionava em Bedfordshire. A governanta, por exemplo, nos é apresentada como uma mulher rude, grosseira, lasciva e impiedosa, apropriada às intenções escusas de Mr B. Ao vê-la pela primeira vez, Pamela diz:

"Then the wicked creature appeared, whom I had never seen but once before, and I was frighted out of my wits.",175

Algumas páginas mais tarde, a jovem fornece ao leitor uma descrição mais detalhada de Mrs Jewkes, como é chamada a criada.

"Now I will give you a picture of this wretch! She is a broad, squat, pursy, fat thing, quite ugly, if any thing human can be so called; about forty years old. She has a huge hand, and an arm as thick - I never saw such a thick arm in my life. Her nose is flat and crooked, and her brows grow down over her eyes; a dead, spiteful, grey, goggling eye: and her face is flat and broad; and as to colour, looks as if it had been pickled a month in saltpetre. I dare say she drinks. She has a hoarse man-like voice, and is as thick as she's long; and yet looks so deadly strong. [...] So that with a heart more ugly than her face, she is at times (especially when she is angry) perfectly frightful.,"176

Ela está na casa para fazer cumprir as ordens de seu patrão, sem demonstrar qualquer simpatia por Pamela ou por sua causa. Ao contrário, Mrs Jewkes tortura a jovem de várias maneiras, roubando-lhe o dinheiro e até mesmo os sapatos, trancando-a no quarto e vigiandoa de todas as maneiras para não permitir que fuja. À chegada, o espaço e seus habitantes corroboram o sentimento de angústia e tensão por que passa a personagem.

Quanto ao interior desta segunda mansão, a falta de descrições e detalhes impede que se tenha uma compreensão mais abrangente deste espaço. Porém, sabe-se que a mansão abriga inúmeros quartos e salas, além de uma biblioteca à qual Pamela tem livre acesso, segundo as palavras de Mrs Jewkes, novamente evidenciando o refinamento, inteligência e gosto da jovem pela leitura e erudição:

“...and you may, moreover, take what books you will out of my master's library.",177

No andar inferior estão algumas das salas a que Pamela se refere ao longo da narrativa, como, por exemplo, o parlour, que é utilizado como sala de jantar. Na passagem que se segue, Pamela vai ao encontro de Mr. B.:

\footnotetext{
175 Pamela, diário, p. 144.

${ }^{176}$ Pamela, diário, p. 152.

${ }^{177}$ Pamela, diário, p. 150.
} 
"I trembled all the way down-stairs; and when I came to the bottom, she [Mrs Jewkes] stept into the parlour before me; [...] 'I thought,' said he, when I came down, 'you should have sat at table with me, while I was in these parts, and when I had not company: but as I find you unworthy of that honour, [...] I call you down to wait on me, while I sup..."178

Há ainda um great parlour, utilizado como sala de visitas:

"At these words she went into the great parlour, where my master was talking very pleasantly with the ladies;","179

E o house-keeper's parlour, a sala de trabalho da governanta, também utilizada como sala de jantar por Pamela e Mrs. Jewkes:

"After my master had dined, he took a turn into the stables, [...] and afterwards, when he came in, he opened the house-keeper's parlour-door, where Mrs. Jewkes and I sat at dinner." 180

Pelas informações que temos do quarto de Pamela na mansão, podemos concluir que ele se localiza no andar superior, já que a jovem freqüentemente "sobe" a seu quarto, ou em suas próprias palavras:

"I sat not long with them; but went up to my closet."181

Sabemos que é fechado por uma "double door with [two] different locks"182, que Mrs Jewkes tranca todas as noites, e que de suas janelas enxergam-se os "espaçosos jardins"183. Contíguo a ele está o closet, onde Pamela guarda seus pertences, como suas roupas, e papel e tinta para suas cartas. Este closet é separado do quarto de dormir por uma porta da qual Pamela recebe uma chave:

"... 'but may I not have to myself the closet in the room where we lie, with the key to lock up my things?' 'I believe I may consent to that,' answered she [Mrs. Jewkes]; 'and I will set it in order for you, and leave the key in the door." 184

${ }^{178}$ Pamela, diário, p. 223.

${ }^{179}$ Pamela, diário, p. 326.

${ }^{180}$ Pamela, diário, p. 248.

${ }^{181}$ Pamela, diário, p. 206.

182 Pamela, diário, p. 148.

${ }^{183}$ Pamela, diário, p. 149.

${ }^{184}$ Pamela, diário, p. 150. 
A partir da segunda metade do romance, passamos a ter também a presença de Mr B. na mansão de Lincolnshire. Nesta casa, seus aposentos encontram-se no andar superior e não no andar inferior como na mansão de Bedfordshire, como se pode concluir a partir desta passagem em que Pamela vai ao seu encontro:

"He sent Mrs Jewkes, about ten o'clock, to bid me come to him. I asked her, 'Whither?' She said she would shew me. I followed her three or four steps, and saw her making to his chamber, the door of which was open: 'I cannot go thither!' said I, and stopt. [...] I heard him say, 'Let her come in, or it shall be worse for her.' 'Well,' said I, 'I cannot go thither, indeed I cannot'; and so I went back again into my closet;"', 185

Nesta casa, Mr B. é colocado em uma posição fisicamente elevada em comparação à situação que tinha em Bedfordshire, pois na primeira mansão seu quarto se localizava claramente no andar inferior. Esta mudança de condição física pode ser vista como um indício da elevação moral pela qual a personagem passa neste segundo ambiente.

Iuri Lotman, em seu livro A Estrutura do Texto Artístico, vê a obra artística como um espaço delimitado que busca reproduzir, de maneira finita, o infinito mundo exterior à obra, como é o caso das artes plásticas que reproduzem no espaço bidimensional e limitado de um quadro, o espaço pluridimensional e ilimitado da realidade. Isto, porém, não se restringe somente às artes visuais. Para ele, nossa visão do mundo se constrói a partir de parâmetros espaciais, ou em suas próprias palavras

\begin{abstract}
"Os modelos do mundo sociais, religiosos, políticos, morais, os mais variados, com a ajuda dos quais o homem [...] confere sentido à vida que o rodeia, encontram-se invariavelmente providos de características espaciais, quer sob a forma da oposição 'céu-terra' [...], quer sob a forma de uma certa hierarquia político-social com uma oposição marcada dos 'altos' aos 'baixos', noutro momento sob a forma de uma marca moral da oposição 'direita-esquerda'.,"186
\end{abstract}

Em suas análises de textos literários, Lotman busca compreender como o espaço do texto assume formas da estrutura do espaço do universo. Assim, ele observou nas poesias de Tiutchev uma organização vertical do espaço em que o alto estaria associado à espiritualidade e o baixo à materialidade. Buscando uma correlação com nosso romance, poderíamos dizer aqui que esta elevação espacial de Mr B. corresponderia à sua elevação moral, num entendimento de que o baixo corresponderia à materialidade, ou seja, sua atitude mundana, egoísta e limitada e o alto à espiritualidade, ou à renovação de seus sentimentos

\footnotetext{
${ }^{185}$ Pamela, diário, p. 233.

${ }^{186}$ LOTMAN, I. A Estrutura do Texto Artístico. Lisboa, Estampa, 1978. p. 359.
} 
iniciais por outros mais nobres, em um movimento na direção do espaço verticalmente ilimitado acima da casa, que abre caminho a novas formas de pensar e de agir. Esta oposição 'alto-baixo' seria aqui entendida como a oposição 'bem-mal', 'sagrado-material' e 'ilimitadolimitado'. Ao ascender espacialmente, Mr B. estaria iniciando um percurso rumo ao sagrado, ao novo e ao ilimitado. Este seria um exemplo de como “...o modelo espacial do mundo torna-se nestes textos um elemento organizador, em volta do qual se constroem também as suas características não espaciais." 187

Ainda nesta casa, podemos inferir pela narrativa que, após o casamento, o casal compartilha o mesmo aposento, instalando-se no quarto que havia sido dos pais de $\mathrm{Mr} \mathrm{B}$., novamente no andar superior da casa, como Lady Davers nos mostra quando vai à procura dos dois, sem saber que a esta altura eles já haviam se casado.

\footnotetext{
"My master had given orders to Mrs. Jewkes not to let him be disturbed till the usual breakfast-time, as he had sat up all night before; but it seems my lady, knowing his usual hour to be six, arose about that time, and being resolved to find out whether one chamber served us both, and if so, to have witness of our being together, raised also her kinsman and her woman, and at about half an hour after six rapped at our chamberdoor. My master, waking, asked, Who was there? 'Open the door,' said my lady; 'open it this minute!' I said, clinging about his neck, in great terror, 'Dear, dear sir, pray, pray, sir, don't open the door!' 'Fear nothing, Pamela,' said he."' 188

“...'Ay,' said she [Lady Davers], [...] But though I came up with a resolution to be temperate, and to expostulate with you on your avoiding me so brutally, yet cannot I have patience to look upon the bed in which I was born, as the guilty scene of your wickedness with such a,,$- " 189$
}

Além das referências relativas ao interior da mansão, em Lincolnshire grande parte dos acontecimentos da narrativa acontece no espaço externo, principalmente nos jardins. Para se ter uma idéia de sua extensão, Pamela relata, na passagem que se segue, um passeio ao ar livre de cinco ou seis milhas que faz com Mrs Jewkes.

"I have been permitted to take an airing five or six miles, with Mrs Jewkes."190

\footnotetext{
${ }^{187}$ Id., ibid., p. 363.

${ }^{188}$ Pamela, diário, p. 434.

${ }^{189}$ Pamela, diário, p. 437-438.

${ }^{190}$ Pamela, diário, p. 180.
} 
Eles são descritos por Pamela como "large and pleasant"191, possuem um lago e, próximo à casa, há uma horta com canteiros de ervas e flores. Estes são contidos por um muro e próximo à horta há uma porta chaveada que dá acesso ao campo; cruzando-se este campo, chega-se à vila, que se localiza "about three miles distant" 192

"...let that sun-flower by the back-door of the garden be the place; I [Mr. Williams] have a key to that door; for it is my nearest way to the village."193

Estes jardins são entremeados por caminhos de pedra ${ }^{194}$ e de grama ${ }^{195}$ e ornados com bancos ${ }^{196}$ próprios para o descanso e a observação da paisagem. O lago é o grande atrativo do jardim. Nele pode-se pescar sentado sobre suas margens gramadas ou apenas admirar a paisagem. Pamela assim o descreve:

"We then talked of the garden, how large and pleasant, and the like; and sat down on the turfted slope of the fish-pond, to see the fishes play upon the surface of the water;", 197

Além dos caminhos, do lago e da horta, o jardim abriga também construções, recantos e jardins privativos, como a "little alcove" 198 para onde ela é levada por Mr B. em um de seus muitos passeios pela propriedade, ou a "great alcove"199 onde Mr B. recebe seus convidados e os apresenta a Pamela. O trecho transcrito a seguir descreve esta alcova e nos oferece uma idéia mais detalhada de como os jardins estão representados no romance.

"My master, conducting them [the neighbours] into the garden, led them into the largest alcove [...] This alcove fronts the longest gravel-walk in the garden, so that they saw me all the way I came [...] They all, I saw, ...stood at the opened windows of the alcove, and in the door-way, looking full at me. [...]'Give me your hand,' said he [Mr. B.], 'my good girl; you walk too fast'... I did so, with a curt'sy, and he led me up the steps of the alcove [...] 'Pray, dear madam, sit down by me,' said Mrs Jones. And they all sat down." 200

\footnotetext{
${ }^{191}$ Pamela, diário, p. 159.

192 Pamela, diário, p. 149.

193 Pamela, diário, p. 159.

${ }^{194}$ Pamela, diário, p. 320.

195 Pamela, diário, p. 163.

${ }^{196}$ Pamela, diário, p. 164.

${ }^{197}$ Pamela, diário, p. 159.

198 Pamela, diário, p. 247.

${ }^{199}$ Pamela, diário, p. 320.

${ }^{200}$ Pamela, diário, pp. 320-321.
} 
A partir dos detalhes do texto, notamos que esta alcova é uma construção envidraçada, fechada com janelas e portas, o que faz dela um lugar protegido e reservado, possibilitando o uso do jardim mesmo em condições menos favoráveis de clima.

Também se encontram na parte externa da mansão uma out-house $e^{201}$, usada para guardar carvão e madeira para uso familiar, os aposentos dos empregados, chamados de outoffices $^{202}$ e os estábulos ${ }^{203}$. A propriedade ainda possui uma capela, onde é realizado o casamento de Pamela e Mr B., que não vinha sendo usada como tal há duas décadas, mas vinha servindo como depósito. Após uma reforma e limpeza, a capela é descrita como:

“...a very pretty one, and very decent. [...] And when I came up towards the little pretty altar-piece, while they were looking at a communion-picture, and saying it was prettily done, I gently stepped..."204

Após o casamento, Pamela tem a promessa de Mr B. de que a capela nunca mais será usada como depósito, mas que será sempre um local de agradecimento e adoração a Deus. Esta passagem torna evidente que a reforma moral pela qual passa Mr B. inclui também uma reforma religiosa, uma vez que após o casamento ele se torna novamente um homem temente a Deus, abandonando sua vida libertina e passando a freqüentar a igreja aos domingos com Pamela. Podemos interpretar a reforma do espaço interior da capela como a materialização no romance da reforma moral interior pela qual passam as personagens. $\mathrm{O}$ casamento entre ambas, visto como o coroamento de sua felicidade e realização, somente pode se dar depois de uma profunda reformulação pessoal. Analogamente, a benção de tal união somente pode ocorrer depois que a capela passa por uma vasta reformulação de seu espaço e do uso atribuído a ele. Observamos novamente a intrincada relação que o romance estabelece entre as personagens, o espaço e o enredo.

\subsection{A importância do espaço exterior}

Neste segundo ambiente, mantém-se a importância dada ao espaço de recolhimento interior, o closet, onde Pamela escreve seu diário, teme por seu futuro, planeja suas fugas frustradas e finalmente alegra-se com sua conquista.

\footnotetext{
${ }^{201}$ Pamela, diário, p. 214.

${ }^{202}$ Pamela, diário, p. 215.

${ }^{203}$ Pamela, diário, p. 219.

${ }^{204}$ Pamela, diário, p. 342.
} 
Também em Lincolnshire ele é visto como espaço de refúgio e força interior presentes no conceito de intimidade, aqui manifestada tanto de forma física quanto psicológica. No closet encontramos o armário, as gavetas, as caixas e os cofres: objetos que contêm nossas lembranças, memórias e segredos. É neste espaço que organizamos e ordenamos as peças de nossa intimidade física e os pensamentos e sentimentos de nossa intimidade psicológica. Além disso, ele representa nosso espaço de recolhimento para onde nos retiramos nos momentos de dificuldade, onde nos escondemos em face ao medo e para onde corremos ao nos regozijarmos com as alegrias da vida. Em seu estudo sobre "as imagens do espaço feliz" ${ }^{205}$, Bachelard afirma que a casa é naturalmente associada à vida humana. Segundo sua ótica,

"Tal objeto [a casa] deveria resistir a metáforas que acolhem o corpo humano, a alma humana. Mas a transposição para o humano ocorre de imediato, assim que encaramos a casa como um espaço de conforto e intimidade, como um espaço que deve condensar e defender a intimidade."206

Para Pamela, seu closet, em ambas as casas, está associado aos valores humanos de resistência e proteção. É neste espaço que ela se refugia das investidas de Mr B. e que busca organização para seus pensamentos confusos e sentimentos exacerbados. Esta característica de intimidade do closet é o que incita Mr B. a invadi-lo, assim como são os segredos expostos nas cartas que o incitam a lê-las. Contudo, são sua curiosidade de homem e sua prepotência de patrão que determinam sua derrota, uma vez que sua transformação se dá através dos escritos de Pamela, do contato com as pressupostas aspirações mais íntimas da jovem. Ao final, ao ser vencido pela retórica da criada é como se ele tivesse sido pego em sua própria armadilha. Sua estratégia inábil de invadir a intimidade física e psicológica da jovem, tentando apoderar-se de seu corpo ou de seus segredos, é justamente o que o coloca nas mãos de Pamela.

Há ainda outro fator associado à intimidade do closet que aparece com mais intensidade na mansão de Lincolnshire: a idéia de solidão. Nesta segunda casa, onde Pamela é mantida como prisioneira, ela não encontra aliados. Nenhum dos empregados está disposto a ajudá-la nem sequer compartilham de sua dor. Mr Williams, o pároco, que poderia significar um apoio, é neutralizado pela engenhosa criatividade de Mrs Jewkes e os vizinhos, a quem ele recorre, se negam a agir contra a vontade de $\mathrm{Mr}$ B. Neste ambiente Pamela mergulha profundamente na solidão, tendo sua escrita como único refúgio. No entanto, a

\footnotetext{
${ }^{205}$ BACHELARD, G. A Poética do Espaço. São Paulo, Martins Fontes, 1993. p. 19.

${ }^{206}$ Id., ibid., pp. 63-64.
} 
solidão está intrinsecamente relacionada à intimidade. Ela é necessária para que a jovem possa se aprofundar em seu íntimo, para que possa ordenar suas dúvidas e melhor compreender seus desejos e anseios, em outras palavras, a solidão lhe permite ir ao fundo de seu ser, analisar-se, modificar-se e fortalecer-se e, deste modo, preparar-se para sua vida futura. Nas palavras de Bachelard "Quando a grande solidão do homem se aprofunda, as duas imensidões [o espaço da intimidade e o espaço do mundo] se tocam, se confundem." ${ }^{207}$

Nesta segunda mansão também observamos uma inegável importância atribuída ao espaço da intimidade. Entretanto, grande parte das cenas neste segundo ambiente se desenvolve no exterior da casa: nos jardins e em seus arredores. Logo após sua chegada, há várias menções a passeios pelo jardim que Pamela faz em companhia de Mrs Jewkes. Além disso, é neste espaço que, recém-chegada, Pamela busca aliança com Mr Williams, estabelecendo com o pároco uma correspondência sob um girassol plantado em um dos canteiros da horta, já que a conversa entre eles é quase que constantemente vigiada pela governanta.

"Mr Williams came to see us, and took a walk with us one of the times; and while her [Mrs Jewkes's] back was turned [...] I said, 'Sir, I see two tiles upon that parsley-bed: might not one cover them with mould, with a note between them, on occasion?' 'A good hint!' said he: 'let that sun-flower by the back-door of the garden be the place;",208

Além disso, há várias caminhadas que Pamela faz com Mr B. após sua chegada. Em uma dessas, ele a leva a uma "little alcove in the further part of the garden" $" 209$, onde tenta novamente obter seus favores. Algumas cenas mais tarde, no jardim à beira do lago, Mr B. declara abertamente seu amor por Pamela. Ainda nos jardins da mansão temos a cena na "great alcove" 210 , em que Pamela é apresentada aos ilustres vizinhos de $\mathrm{Mr}$ B. em Lincolnshire.

É também no exterior da casa, durante um passeio de charrete, que Mr B., pela primeira vez, expressa o desejo de casar-se com Pamela e os dois consideram todos os aspectos envolvidos em tal decisão levando-se em conta a distância social que os separa.

Também durante este passeio podemos observar mais uma vez, expressa em palavras, a grande importância atribuída ao espaço na narrativa. Ao declarar-se a Pamela, Mr B. afirma:

\footnotetext{
${ }^{207}$ BACHELARD, 1993, p. 207.

${ }^{208}$ Pamela, diário, pp. 158-159.

${ }^{209}$ Pamela, diário, p. 247.

${ }^{210}$ Pamela, diário, p. 320.
} 
" 'I do own to you, my Pamela,' said he, 'that I love you with a purer flame than ever I knew in my whole life! A flame, to which I was a stranger, and which commenced for you in the garden;',"211

Apesar de explícita, esta referência ao jardim é muito vaga para podermos nos assegurar de qual foi exatamente o momento em que Mr B.se deu conta de seu amor por Pamela. Esta pode ser uma alusão ao episódio ocorrido na summer-house, ainda na mansão de Bedfordshire, quando logo no início da narrativa Mr B. rouba um beijo de Pamela; uma menção ao episódio do lago, cuja leitura provocou no jovem aristocrata um momento de reflexão e gerou a posterior mudança de seus sentimentos; ou ainda à cena no jardim em que ele declara abertamente seu amor a ela, ambas ocorridas no exterior da mansão de Lincolnshire. Entretanto, mesmo que não saibamos claramente a que se refere $\mathrm{Mr}$ B., o que nos importa neste estudo é observar a clara e intrincada correlação que se estabelece entre espaço, enredo e personagem no romance. Como já foi dito, o espaço se estabelece dentro da obra como seu elemento organizador, já que as relações entre as personagens se dão sempre a partir de ou em referência ao espaço das mansões.

Além das cenas que se desenrolam nos jardins da mansão de Lincolnshire, há também alguns passeios de charrete para além da propriedade de $\mathrm{Mr} \mathrm{B}$. que merecem ser mencionados. Durante estes percursos, o foco da narrativa está sempre nos aspectos da vida futura do casal e não há nenhuma referência explícita ao local por onde passeiam. No entanto, em um deles temos acesso a uma descrição do entorno da propriedade, em que podemos nos deleitar com o belo campo inglês dos prados e riachos.

\footnotetext{
" 'There is a turning in the road,' said he, 'about five miles off, which goes round a meadow, that has a pleasant footway, on the banks of a little brook, and a double row of limes on each side, where the gentry in the neighbourhood sometimes walk and converse; and sometimes angle. (I'll shew it you in our next airing.)"212
}

É em outro passeio por este espaço exterior à propriedade que, algumas cenas antes, Mr B. retoma seu relacionamento com Mr Williams, em uma tentativa de agradar Pamela, mas também e principalmente demonstrando que sua elevação moral não se restringe ao espaço limitado da vida doméstica do casal, representado aqui pela casa, mas que se estende para além dos limites da mansão. Esta incursão reconciliadora nos campos que circundam a propriedade demonstra que a elevação moral da personagem é real, profunda e ilimitada.

\footnotetext{
${ }^{211}$ Pamela, diário, pp. 301-302.

212 Pamela, diário, p. 318.
} 
O grande número de cenas externas nesta segunda mansão pode ser entendido como uma espécie de contraponto ao espaço da intimidade representado pela casa e, mais especificamente, pelo closet. Em seu estudo sobre a summer-house em Clarissa, Karen Lipsedge afirma que, com o desenvolvimento do hábito da visitação a partir do século XVIII, a casa passou a ser um indício do caráter e do gosto de seus moradores. Semelhantemente, os jardins, vistos como extensão da casa, revelavam também o refinamento de seu proprietário. Sabemos pela narrativa que tanto a casa quanto os jardins abrigavam espaços reservados às visitas, pois $\mathrm{Mr}$ B. recebe seus vizinhos em Lincolnshire tanto no great parlour dentro da casa como na great alcove nos jardins, demonstrando que, assim como o interior da casa, os jardins também deveriam proporcionar a seus usuários espaços privados propícios à reflexão e ao isolamento e espaços de convívio social reservados ao entretenimento dos convidados.

Se analisarmos o uso que é feito do jardim nesta segunda mansão, observaremos que, antes da chegada de Mr B. à propriedade, Pamela tem acesso ao exterior da mansão em companhia da governanta. Ali ela passeia, aprecia a beleza da natureza e empreende suas tentativas frustradas de fuga, primeiramente buscando aliança com os vizinhos através do pároco e posteriormente em uma real tentativa de sair para além dos muros que limitam a casa. Após a chegada de Mr B., os jardins passam a ser palco de vários encontros entre os dois e do casal com as famílias vizinhas. Pela descrição que temos do jardim, este parece obedecer a um paisagismo mais formal, seguindo o estilo italiano ou francês, mais elaborado e separado do campo cultivado e dos pastos por um muro.

Para Lipsedge, em sua análise de Clarissa, tradicionalmente, ao estudar o espaço no romance, mais atenção se deu ao espaço interior, da intimidade e da privacidade. ${ }^{213}$ Pode-se dizer o mesmo de Pamela. O espaço interior, e principalmente o closet, foi mais amplamente analisado, devido à grande ênfase dada à privacidade no romance. No entanto, observamos neste segundo ambiente que um grande número de cenas se desenvolve no espaço externo. Buscando uma explicação para a relação dialética que se estabelece entre os espaços 'aberto e fechado' dentro da obra podemos novamente recorrer a Bachelard. Para ele, o interior é o espaço da intimidade física e psicológica, o que está de acordo com a constituição espacial no romance, pois no recesso de seu closet a personagem organiza e ordena seus pensamentos e sentimentos através do ato da escrita. O espaço de sua mente, contudo, é infinito e não pode ser contido por delimitações físicas. Esta imensidão, em que nos permitimos os mais ousados vôos, se contrapõe às restrições espaciais impostas pela forma física. Pamela, portanto, pode

\footnotetext{
${ }^{213}$ LIPSEDGE, 2006, p. 187.
} 
criar em sua mente as mais fantásticas tentativas de fuga, mas não pode empreendê-las senão no espaço externo, aberto, que dá acesso a um número sem fim de possibilidades. Ao pensarmos o espaço interno como restrito e contido, e por isso mesmo de refúgio e proteção, observamos que ele não permite nenhuma ação além de seus limites físicos. $\mathrm{O}$ exterior, por outro lado, permite a tentativa de empreendimento de todo e qualquer sonho, pois é imenso e infinito. Para Bachelard, "Se assim podemos dizer, os dois espaços, o espaço íntimo e o espaço exterior, vêm constantemente estimular um ao outro em seu crescimento."214

Desta forma, a organização dos sentimentos e pensamentos de Pamela se dá dentro do closet, mas a realização de seus sonhos somente pode se dar no exterior. O espaço externo se qualifica então como o espaço da consumação dos desejos e anseios mais secretos das personagens, até mesmo a união de um casal tão distante socialmente. Talvez por isso, a declaração de amor, o pedido de casamento e as considerações sobre sua vida futura se dêem no exterior da mansão, já que este é o espaço da imensidão que se abre a um número infinito de possibilidades e a um novo modo de vida.

Dentro desta perspectiva, parece claro que a modificação na situação de ambas as personagens não tenha ocorrido no espaço da tradição e das relações conhecidas da primeira mansão. A segunda mansão, por seu isolamento e seu distanciamento físicos, assim como pela neutralidade de seu espaço, propicia a reflexão, a auto-análise e a conseqüente elevação das personagens. Neste entendimento, o homem é o ser que cria em seu interior, mas necessita do exterior para realizar suas ações. Após tê-las realizado ele volta ao seu interior para a elaboração dos sentimentos provocados por tal ação e para a criação de novas idéias. Deste modo, a mente de infinitas possibilidades precisa do espaço finito para sua organização, mas do espaço infinito para sua realização.

Neste jogo entre interior e exterior, Bachelard também menciona a linguagem como algo que traz em si a dialética do aberto e do fechado, pois "pelo sentido, ela se fecha; pela expressão poética, ela se abre"215. Aqui também podemos buscar uma correlação com a situação de nossa narradora-protagonista. Uma vez que a história chega a nós através de sua narrativa, podemos dizer que ela contém o espaço fechado da idéia expressa, mas que em seu sentido oculto se abre a uma infinidade de possíveis leituras, tanto hoje quanto na época de sua publicação.

\footnotetext{
${ }^{214}$ BACHELARD, 1993, p. 205.

${ }^{215}$ Id., ibid., p. 224.
} 
Finalmente, Bachelard afirma que,

“... o ser quer se manifestar e quer se ocultar, os movimentos de fechamento e abertura são tão numerosos, tão freqüentemente invertidos, tão carregados de hesitação, que poderíamos concluir com esta fórmula: o homem é o ser entreaberto., ${ }^{216}$

Desta forma, os seres ou as personagens transitam entre o aberto e o fechado no movimento dialético de se abrir e se fechar, de mostrar e ocultar, e este sentimento vem materializado na obra pelo entrar e sair, pelo esconder-se no closet e expor-se no jardim., demonstrando mais uma vez a intrínseca ligação entre espaço e personagem.

\subsection{Uma cena no exterior da mansão de Lincolnshire: às margens do lago}

Devido ao grande número de cenas que se desenvolvem no exterior desta mansão, parece ser oportuno estudar mais profundamente uma das cenas de maior importância no romance, já que é a partir da leitura sobre ela no diário da jovem que os sentimentos de Mr B. pela criada sofrem uma grande e profunda mudança.

"He put the papers in his pocket, when he had read my reflections and my thanks for escaping from myself; and said, taking me about the waist, 'O my dear girl! you have touched me sensibly with your mournful tale, and your reflections upon it. I should truly have been very miserable had that happened which might have happened. I see you have been used too roughly; and it is a mercy you stood proof in that dangerous moment. ",217

Referimo-nos à cena na qual Pamela considera a possibilidade de atirar-se ao lago para pôr fìm à sua angústia. É à margem deste lago que se dá o solilóquio em que Pamela considera a morte como solução para os problemas desta vida e conclui que somente Deus tem o poder de saber e decidir sobre o que é melhor para os seres humanos, pois sua visão não é limitada e restrita, mas onipresente e onisciente.

Esta cena tem início às onze horas da noite quando Mrs Jewkes chega ao quarto para dormir e Pamela, ainda em seu closet, registra no diário seu plano de escapar da casa através das barras da janela. No parágrafo seguinte, o leitor já é apresentado ao desfecho frustrado de fuga da jovem em um relato que se dá quatro dias mais tarde.

\footnotetext{
${ }^{216}$ Id., ibid., p. 225.

${ }^{217}$ Pamela, diário, p. 276.
} 
A exposição desta cena abre com o intenso sentimento de desespero de Pamela por se encontrar ainda na mesma situação como prisioneira da casa, mas de fato feliz por ter escapado, graças à "Graça Divina"218, a um inimigo ainda pior: sua própria fraqueza e presunção. A intensidade de sentimentos fica clara desde as primeiras linhas quando Pamela diz:

"And distress indeed! For here I am still! And every thing has been worse and worse! O the unhappy Pamela! Without any hope left, and ruined in all my contrivances!"219

Logo em seguida, sabemos que o retardo da narrativa se deve à debilidade física da jovem, pois, segundo ela,

“...indeed I have been so weak, that till yesterday evening, I have not been able to hold a pen." 220

A partir destas considerações iniciais, ela dá início à descrição da fuga em que menciona os objetos que leva consigo e descreve em detalhe o processo que inclui passar através das barras da janela, pular sobre o telhado e daí para o chão. Uma vez no jardim, Pamela esconde seus escritos debaixo de uma roseira e vai em direção ao lago, onde joga seu casaco, seu lenço e sua touca para simular um afogamento. Neste ponto, Pamela interrompe a descrição para ressaltar que

“...the clock struck twelve, just as I got out; and it was a dark misty night, and very cold; but I was not then sensible of it.",221

Estes pequenos detalhes, aparentemente irrelevantes, são de fato indícios bastante contundentes da grande mudança que está para acontecer no desenrolar dos fatos. O primeiro elemento que chama a atenção é o relógio que bate as doze badaladas indicando que a hora é precisa: meia-noite. Além disso, sabemos que a noite é escura, fria e nevoenta. Ao buscarmos uma explicação para o profundo simbolismo da cena podemos concluir que estes fatores estão diretamente relacionados ao estado de espírito da personagem e aos novos rumos que tomará a narrativa.

A meia-noite, por exemplo, é o ponto de intensidade máxima da noite, mas também a origem de um novo dia que despontará trazendo a claridade e a luz do sol. Analogamente,

\footnotetext{
218 Pamela, diário, p. 209.

${ }^{219}$ Pamela, diário, p. 209.

${ }^{220}$ Pamela, diário, p. 209.

${ }^{221}$ Pamela, diário, p. 210.
} 
Pamela atinge nesta cena o auge de seu sofrimento, angústia e desconsolo, mas é justamente através deste ponto máximo de padecimento que se dá o surgir de uma nova etapa no desenrolar dos acontecimentos, com a chegada de Mr B. à casa, sua leitura do diário da jovem, e a nova caracterização de seus sentimentos por ela. Como o raiar de um novo dia, que clareia tudo à sua volta, a mente das personagens é iluminada por uma nova compreensão dos fatos que lhes aclara o entendimento, permitindo que elas se dêem conta do amor que sentem uma pelo outra. Ademais, a meia-noite pode ser também entendida como a culminação do Sol espiritual. No romance podemos associar a uma espécie de confirmação religiosa da jovem, pois, através de sua entrega a Deus, ela reconhece a incapacidade humana de julgar os fatos a partir de um ponto de vista elevado e destacado, abrindo assim a possibilidade para a realização dos desígnios divinos e a consumação de seus anseios mais profundos.

Do mesmo modo, a noite simboliza o tempo das gestações e germinações que irão desabrochar no dia, na forma de manifestação da vida. A noite é indeterminada; é a imagem do inconsciente humano, que aflora trazendo à tona pensamentos e sentimentos desconhecidos. Em um desvio de sua conduta habitual, vemos o inconsciente da jovem se revelar no momento em que ela fala:

\footnotetext{
"And then, thought I (and O that thought was surely of the devil's instigation; for it was very soothing and powerful with me) these wicked wretches, who now have no remorse, no pity on me, will then be moved to lament their misdoings; and when they see the dead corpse of the miserable Pamela dragged out to these dewy banks, and lying breathless at their feet, they will find that remorse to soften their obdurate hearts, which, now, has no place in them! And my master, my angry master, will then forget his resentments, and say, 'Alas!' [...] 'This is the unhappy Pamela! whom I have so causelessly persecuted and destroyed! Now do I see she preferred her honesty to her life. She, poor girl! was no hypocrite, no deceiver; but really was the innocent creature she pretended to be!" ",222
}

Como ao longo de todo o romance, esta cena também pode ser lida como a expressão dos pesares mais íntimos da jovem, como o faz $\mathrm{Mr}$ B. ao se deixar enternecer pela intensidade de seu relato, ou como mais uma conquista da retórica de Pamela, que, antecipando o interesse de seu patrão por seus escritos, faz uso das palavras e dos sentimentos como meio de persuasão e convencimento, na tentativa de alcançar seus objetivos mais secretos.

\footnotetext{
${ }^{222}$ Pamela, diário, pp. 211-212.
} 
Para corroborar a sensação de imprecisão, a noite é obscurecida pela névoa. O nevoeiro é o símbolo do indeterminado, de uma fase de evolução em que as formas antigas estão desaparecendo, mas ainda não foram substituídas por formas novas precisas. O momento em que tudo está tomado pelo nevoeiro representa um período transitório entre dois estados, reforçando a idéia de que esta é uma cena de passagem no romance entre um entendimento primeiro dos fatos para uma nova concepção da vida.

Os parágrafos que se seguem expõem a frustrada tentativa de fuga da jovem. Seu plano inicial incluía abrir a porta que dava ao campo com uma cópia da chave que lhe tinha sido dada por Mr Williams, mas ela logo descobre que Mrs Jewkes tinha tido o cuidado de trocar a fechadura. Ao pensar nas conseqüências que a fuga não empreendida lhe traria na casa, ela tenta pular o muro, mas ao se apoiar nele os tijolos se desfazem e ela cai ao chão. Com pés e pernas machucados e tendo sido atingida na cabeça por um dos tijolos do muro, Pamela fica estirada por alguns minutos sem conseguir se mover. Não sabendo o que fazer e sentindo-se absolutamente desolada, dirige-se ao lago pensando em atirar-se nele de modo a pôr fim à sua dor. A partir daí o que temos é o relato de suas angústias e tristeza:

"God forgive me! but a sad thought came just then into my head! I tremble to think of
it! Indeed my apprehensions of the usage I should meet with, had like to have made me
miserable for ever! O my dear, dear parents, forgive your poor child! But being then
quite desperate, I crept along, till I could raise myself on my staggering feet; and away
limped I! What to do, but to throw myself into the pond, and so put a period to all my
terrors in this world! But, oh! to find them infinitely aggravated in a miserable eternity!
had I not by the Divine Grace been with-held."223

Às margens frias e úmidas do lago, Pamela considera o grande enigma que ao longo dos tempos tem aturdido a consciência do homem: o mistério da vida e da morte. Novamente ao buscarmos uma explicação na simbologia, vemos que o lago simboliza as forças permanentes da criação. Ele pode ser visto como a morada dos deuses ou como um palácio de onde surgem fadas que atraem os homens para sua morte. O lago é o olho da terra por onde os habitantes do subterrâneo podem ver os homens. Seu elemento predominante é a água que pode ser entendida como fonte de vida, meio de purificação e de regeneração, reforçando a escolha de Pamela pela vida e pela purificação através do sofrimento. Fortemente regenerada após este episódio, a jovem está espiritualmente apta a receber a recompensa de sua ascensão social.

${ }^{223}$ Pamela, diário, p. 211. 
Contudo, a principal característica do lago parece ser sua extensão expressa nas palavras "so large a piece of water" 224 . A partir disso podemos traçar um paralelo entre o lago e a mente. Assim como o lago é vasto, a mente é infinita e permite um número sem fim de associações, pensamentos e conclusões. Além disso, as profundezas do lago revelam uma grandeza oculta que também se manifesta na mente que oculta nuances de sentimento e pensamento que somente se mostram a nós em momentos extremos. Pode-se compreender a profundeza das águas do lago como uma metáfora para a viagem que Pamela empreende ao mais profundo de ser: para nascer renovada a jovem deve descer às profundezas de seu sofrimento para que possa ressurgir com forças renovadas. Podemos ver também nas águas do lago um espelho que devolve, a quem se olha nele, sua própria imagem refletida. Sob este entendimento, as águas do lago colocam Pamela diante de si mesma obrigando-a a ponderar sobre seus atos e a medir as consequiências de cada decisão tomada.

Há ainda dois elementos simbólicos relevantes nesta cena: o muro e a porta. A porta significa a passagem entre dois estados: o conhecido e o desconhecido. Por estar trancada, a porta não permite o acesso ao desconhecido, assim como Pamela não se aventura no desconhecido mistério da morte, preferindo o reino dos sofrimentos conhecidos. Semelhantemente, o muro é a proteção que encerra um mundo, evitando que as influências externas o penetrem ${ }^{225}$. Pamela teme as vicissitudes que podem advir do desconhecido, como ela mesma nos conta:

"This, my dear father and mother, is the issue of your poor Pamela's fruitless enterprize; and who knows, if I had got out at the back-door, whether I had been at all in a better case, moneyless, friendless, as I am, and in a strange place!",226

Ainda no parágrafo em que Pamela considera a possibilidade de atirar-se ao lago, observamos o grifo em itálico nos termos eternidade e Graça Divina. A eternidade é um tempo infinito assim como é infinita a graça de Deus. De fronte ao lago Pamela considera a limitada visão humana diante da ilimitada sabedoria divina:

"What art thou about to do, wretched Pamela? How knowest thou, though the prospect be all dark to thy short-sighted eye, what God may do for thee, even when all human means fail?",227

${ }^{224}$ Pamela, diário, p. 214.

${ }^{225}$ Os significados dos símbolos utilizados na análise desta cena foram extraídos do "Dicionário de Símbolos" de Jean Chevalier e Alain Gheerbrant: CHEVALIER, J. \& GHEERBRANT, A. Dicionário de Símbolos: mitos, sonhos, costumes, gestos, formas, figuras, cores, números. Tradução Vera da Costa e Silva et al. 21ed. Rio de Janeiro, José Olympio, 2007.

${ }^{226}$ Pamela, diário, p. 214.

227 Pamela, diário, p. 212. 


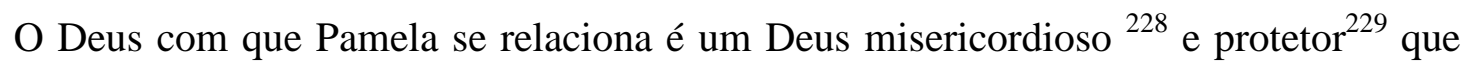
ampara os inocentes e que nunca dá ao homem um fardo maior do que o que ele tem a capacidade de suportar:

"God Almighty would not lay me under these sore afflictions, if he had not given me strength to grapple with them...."230

Este aspecto religioso, observado no romance, era firmemente presente na vida das pessoas naquela época. Historicamente sabe-se que a Inglaterra do século XVIII era um país fortemente cristão em todas as camadas sociais. Muitas famílias possuíam uma Bíblia, um livro de orações e algum manual religioso em casa. ${ }^{231}$ Além disso, muitos escritos seculares tinham um forte cunho religioso como, por exemplo, Robinson Crusoe, de Daniel Defoe, publicado em 1719, onde a religião aparece como forma de instrução através do exemplo da personagem.

Os maiores pensadores da época, Locke e Newton, eram homens religiosos. Para Newton, um Ser superior inteligente e poderoso governava as leis da natureza, mantendo o mundo em harmonia. Essa natureza era uma prova da existência de Deus, como forma da manifestação da sabedoria divina na criação. ${ }^{232}$

Locke, por sua vez, afirma em An Essay Concerning Human Understanding que o homem não nasce com uma idéia pré-concebida de Deus ou da Religião, mas que a crença religiosa é o resultado de um processo de reflexão mental. A prova da existência de Deus está no reconhecimento de sua própria existência e na necessidade lógica de uma causa primeira que a explique. ${ }^{233}$

A imagem de Deus, retratada em Pamela, é a imagem de um Deus que se manifesta positivamente através da benevolência, misericórdia e compaixão, como observamos nessa cena.

O desenrolar deste relato nos mostra a jovem que considera as várias possibilidades que se apresentam a ela nesse momento. Por um breve instante, ela toma a morte como solução a seus problemas, mas logo depois se questiona sobre sua presunção em achar-se

\footnotetext{
${ }^{228}$ Pamela, diário, pp. 211 e 213.

${ }^{229}$ Pamela, diário, p. 213.

${ }^{230}$ Pamela, diário, p. 212.

${ }^{231}$ SAMBROOK, 1994, p. 31.

${ }^{232}$ Id., ibid., p. 7.

${ }^{233}$ Id., ibid., p. 34.
} 
com o poder de decidir sobre seu destino e caracteriza como fraqueza da mente não suportar com honra os revezes da vida. Desta forma, Pamela conclui

\begin{abstract}
"What then, presumptuous Pamela, dost thou here? Thought I: quit with speed these perilous banks, and fly from these dashing waters, that seem in their meaning murmurs, this still night, to reproach thy rashness! Tempt not God's goodness on the mossy banks, which have been witnesses of thy guilty purpose; and while thou hast power left thee, avoid the temptation [...] And so saying, I arose; but was so stiff with my hurts, so cold with the dew of the night, and the wet grass on which I had sat, as also with the damps arising from so large a piece of water, that with great pain I got from this pond, which now I think of with terror; and bending my limping steps towards the house, took refuge in the corner of an out-house...,234
\end{abstract}

Com estas palavras finaliza-se este episódio, cuja função é central na narrativa e que nos mostra novamente o quão determinante é o espaço na concepção das personagens e no desenrolar do enredo.

Ao final do período em Lincolnshire, após o casamento e a aceitação de Pamela pelas famílias vizinhas e por Lady Davers, a irmã de Mr B., o casal retorna à mansão do início da narrativa, no condado de Bedfordshire. Aqui se desenrolam as cenas finais do romance sem que se nos apresentem novos detalhes do espaço nesta propriedade. Talvez a única cena que valha a pena ressaltar é aquela em que Pamela toma posse de seu novo quarto na mansão: o quarto de sua senhora. Nesta cena nos é oferecida uma breve descrição dos aposentos e de seus objetos, como vemos a seguir:

"He was pleased afterwards to lead me up-stairs, and gave me possession of my lady's dressing-room and cabinet, and her fine repeating-watch and equipage; and, in short, of a complete set of jewels, that were hers. [...] He presented me also with books, pictures, linen, laces, and every thing that was in my late lady's apartment; and bid me call that apartment mine." 235

Embora simples e curta esta cena é um momento chave no enredo do romance, pois representa o coroamento da elevação de Pamela. A posse dos aposentos da senhora é a materialização de sua ascensão social, uma vez que no quarto e nos objetos da senhora estão implícitos o poder e o reconhecimento atribuídos aos membros das classes mais elevadas. Ao adquirir a posse e o uso deste espaço e dos objetos que estão ali contidos, Pamela se constitui como a verdadeira senhora da casa e do coração de Mr B.

\footnotetext{
${ }^{234}$ Pamela, diário, pp. 213-214.
}

${ }^{235}$ Pamela, diário, p. 488. 
Nesta volta à mansão, de onde Pamela havia saído como criada e para onde volta como senhora, a narrativa não fornece detalhes da nova acomodação nos aposentos da casa. Não sabemos, por exemplo, se Pamela passa a dormir no antigo quarto de sua senhora, onde dorme Mr B. e se dormem juntos ou não. Estas últimas páginas do romance concentram-se na nova condição de vida do casal e na aceitação deste pelas famílias vizinhas. Temos, nestas páginas, o relato do reencontro com os outros criados, o primeiro jantar na companhia das famílias vizinhas, o estabelecimento da nova condição dos pais de Pamela, a visita à fazenda onde mora a filha bastarda de Mr B., Miss Sally Godfrey, e a primeira aparição pública do casal na igreja no domingo. Contudo, uma das últimas cenas nos leva de volta à summerhouse do início de nossa história, onde Mr B. rouba o primeiro beijo de Pamela. Agora eles se abrigam da chuva e, num ambiente privado e tranqüilo, ele a informa de que acaba de fazê-la sua herdeira.

"He [Mr. B.] took a walk with me, after breakfast, into the garden, and a little shower falling, he led me for shelter into the summer-house, in the private garden, where he formerly gave me apprehensions; and, sitting down by me, he said, 'I have now finished all that lies on my mind, my dear, and am easy [...] I took it into consideration, that, at present, my family is almost extinct; and that the chief part of my maternal estate, in case I die without issue, will go to another family. And that I ought not to leave my Pamela at the mercy of those to whom my paternal estate, on the like contingency, will devolve. I have, therefore, as human life is uncertain, made such a disposition of my affairs, as will render you absolutely independent; as will secure to you the means of doing a great deal of good, and living as my relict ought to do; and, at the same time, put it out of any body's power to molest your father and mother, in the provision I design them for the remainder of their days: and I have finished all, this very morning,...,236

Nesta, que é uma das cenas finais do romance, voltamos a ter a presença de um elemento importante: a água. Novamente buscando uma explicação simbólica para a água, podemos associá-la à vida e à pureza. Lavados espiritual e moralmente pelo sofrimento, o casal está agora preparado para sua vida futura. Ademais, a água pode ser ainda interpretada como um meio e um lugar de revelação, preparando as personagens para a declaração de que Mr B. acaba de fazer Pamela sua herdeira.

Assim termina o romance, com a prova final da reforma moral de Mr B., sua generosidade e amor por Pamela, e da ascensão social da jovem, com a garantia de um futuro materialmente confortável mesmo que ela não venha a lhe dar filhos.

${ }^{236}$ Pamela, diário, pp. 509-510. 
Esta volta à summer-house do início na narrativa remete o leitor às primeiras demonstrações de interesse do jovem aristocrata pela criada fechando a história em um círculo, um caminho em espiral que leva as personagens, autor e leitor ao lugar de início do conflito central da narrativa. Após este percurso as personagens se encontram elevadas e renovadas, prontas para sua nova vida. Semelhantemente, o leitor também deveria estar mais apto a enfrentar a vida, pois

"By involving the reader, on the page, in problems of interpretation, response and judgement analogous to those he must confront in the world beyond, the novels inform his capacity to make sense of that world and to conduct his life within it." ${ }^{237}$

\subsection{Considerações finais}

Em Pamela, portanto, as relações entre nossa narradora-protagonista e Mr B. se constituem dentro e a partir do espaço das duas mansões da narrativa. O closet, por exemplo, se define como espaço da ordem e da intimidade física a partir de sua relação com a ordenação, a intimidade e a privacidade do espaço psicológico da personagem. Da mesma maneira, os jardins se constituem como o espaço exterior, iluminado pela luz do sol, colorido pelas flores e banhado pelas águas. Este espaço aberto, ainda que delimitado por um muro, é o espaço das ações externas, aquelas que modificam nosso modo de pensar e de agir e imprimem um novo rumo à constituição da vida. As ações que se dão no espaço externo devem ser ponderadas e organizadas no espaço interno para que as mudanças, as novas atitudes, pensamentos e sentimentos, possam ser efetivados. Para tal é necessário que Pamela seja retirada da primeira mansão, espaço que representa a autoridade, a tradição e os costumes da aristocracia inglesa personificados na presença da memória da mãe de Mr B., e levada a um espaço afastado e retirado para que possa se dar a reforma social e moral das personagens. Após a consolidação desta mudança as personagens voltam ao seu espaço de origem, prontas a assumir seu novo status e sua nova condição de vida no espaço inicial da narrativa, previamente habitado e conhecido, porém agora renovado.

Ainda quanto ao espaço, ambas as viagens de ida e vinda de Lincolnshire servem apenas como troca de ambiente, sem receberem qualquer ênfase quanto ao entorno ou os lugares por onde passam. Nada se sabe sobre o percurso, além de algumas referências a vilarejos durante o caminho, e, na viagem de ida, à parada que fazem numa casa de fazenda

${ }^{237}$ KEYMER, 1992, p. 82. 
já na propriedade de Mr B. de onde Pamela tenta fugir sem sucesso. Estas trocas de ambiente têm a função de permitir a modificação da condição das personagens e atuam como uma espécie de túnel que transporta as personagens a um mundo desconhecido e as traz de volta ao mundo conhecido após terem amadurecido e estarem mais aptas a viver de modo mais digno e completo, de acordo com a nova moral que se delineava em meados do século XVIII.

Além disso, observamos no decorrer da narrativa que, ao estabelecer o centro da ação no ambiente doméstico, o romance caracteriza-o como o espaço de domínio da mulher, colocando nas mãos de Pamela o controle sobre todas as cenas que se desenrolam em ambiente interno. Por isso, a criada vence seu patrão em todas as discussões e embates que se dão dentro da casa, uma vez que esta se constitui não somente como seu local de refúgio, mas como o espaço feminino por excelência. Na primeira mansão, mesmo após a morte da senhora, permanece a forte impressão de sua função de criada. Ao trocar de ambiente, Pamela, embora sob o jugo da governanta, não mais se apresenta ao leitor como criada. Após a chegada de Mr B. na casa, ela assume pouco a pouco o controle do ambiente até por fim tomar posse do espaço que é seu por direito no retorno à mansão do início da narrativa. Ao tomar posse do quarto da senhora ao final do romance, temos a consagração de seu comando sobre todos os aspectos que envolvem a vida doméstica, pois sendo mulher é seu o domínio sobre este ambiente.

Em oposição a este ambiente doméstico, temos a caracterização do ambiente público como sendo o espaço de domínio do homem. Nas poucas cenas que se desenrolam para além dos muros da propriedade observamos que o comando está nas mãos de Mr B., como, por exemplo, quando Pamela é raptada e levada à mansão de Lincolnshire, ou ainda quando ela tenta empreender sua fuga, mas é contida pelo espaço ou detida por seu receio de se aventurar em um ambiente desconhecido. Além disso, é também no exterior da propriedade de Lincolnshire, em um hotel a caminho da casa dos pais, que Pamela se dá conta de seus verdadeiros sentimentos por Mr B., reconhece seu amor por ele e decide retornar à mansão ainda que receando por seu futuro.

Sob este entendimento, observamos no romance a consolidação, em termos espaciais, de um modo de vida que começava a se afirmar como uma nova ordem social na primeira metade do século XVIII. Os novos rumos que tomava a História exigiam uma reestruturação do modo de vida tanto do homem quanto da mulher não apenas no âmbito social, mas em todos os campos da existência. Isto aparece retratado não somente no enredo do romance, mas em sua própria constituição, uma vez que os elementos que o compõe apresentam dentro de si os aspectos sociais e históricos da época. Podemos afirmar, portanto, que, em Pamela, a 
relação que se estabelece entre o espaço e as personagens traz dentro de si as novas disposições sociais que iriam ao longo dos séculos modificar por completo a organização da vida, do trabalho e das relações entre os seres, até chegarmos ao modo de vida dos dias de hoje. 


\section{CONCLUSÃO}

O objetivo deste trabalho consistiu na elaboração de uma análise da relação que se estabelece no romance entre dois elementos constitutivos do gênero: personagem e espaço. Ao examinar o espaço levamos em conta tanto o espaço interno, o ambiente da casa, quanto o espaço externo, os jardins e o entorno da propriedade. A partir da leitura, foi possível concluir que estes dois aspectos formais do romance estão intrinsecamente relacionados e interagem de modo consoante na construção do sentido mais profundo do texto.

Este estudo versou sobre o espaço humano e social, a que se refere Milton Santos. Por sua condição de imaterialidade, o espaço é um elemento que não se apresenta de forma concreta e palpável, portanto, uma análise elucidativa não pode restringir-se à forma, mas deve incluir a observação de seu uso e da ligação que se estabelece entre os homens que o ocupam e as atividades nele realizadas.

Em seu ensaio $O$ homem dos avessos, Antonio Candido trata da relação que se estabelece entre o meio e a personagem no romance Grande sertão: veredas de Guimarães Rosa. Neste texto Candido nos faz ver como o artista cria o seu mundo e o seu homem a partir de modelos do mundo real. No entanto, este universo fictício revela-se mais elucidativo, mais amplo e mais significativo do que os dados que a observação comum da realidade pode nos fornecer. ${ }^{238}$ Ele nos mostra como estes dois planos, o real e o ficcional, conferem sentido um ao outro, e como neste jogo, a que todo leitor está submetido, revela-se uma compreensão mais profunda da realidade.

Ao retratar e descrever uma vida humana particular, a literatura the confere um significado universal, “...levando, não à solução, mas à suspensão que marca a verdadeira obra de arte, e permite a sua ressonância na imaginação e na sensibilidade." ${ }^{239}$ Para Candido, um grande romance mistura o real e o irreal levando o leitor a transitar por estas duas esferas. Assim sendo, o romance busca, através da identificação do leitor com as alegrias e sofrimentos da personagem, fazer com que o indivíduo procure refletir sobre sua própria vida na tentativa de absorver seu sentido mais amplo. A experiência da leitura não deve ser infrutífera, mas sim fornecer ao leitor instrumentos que o tornarão mais apto a se defrontar

\footnotetext{
${ }^{238}$ ANTONIO CANDIDO. “O Homem dos Avessos". In: ANTONIO CANDIDO. Tese e Antítese. 5ed. Rio de Janeiro, Ouro sobre Azul, 2006. p. 111.

${ }^{239}$ Id., ibid., pp. 112-113.
} 
com a realidade da vida cotidiana. Caracteriza-se assim o aspecto de fonte de conhecimento do mundo atribuído à literatura.

Se nos dias de hoje observamos uma supremacia do indivíduo em detrimento da coletividade, podemos dizer que esta tendência ganhou força no século XVIII. Esta foi uma época de grandes transformações sociais e econômicas que originaram um novo modo de vida. As alterações na concepção do mundo que se estabeleceram neste período trouxeram para o primeiro plano a realização do ser com a conseqüente ênfase nas noções de privacidade, propriedade e direito individual. A literatura, como forma de representação escrita da vida humana, também retratou estas mudanças apresentando pelas mãos dos primeiros romancistas um novo gênero de prosa de ficção.

Pamela pertence a este momento literário de ascensão do romance. Segundo Ian Watt, Richardson é um dos escritores que buscou dar forma a um novo modo de narrar que contemplasse a representação autêntica da experiência humana. Conforme Vasconcelos, este efeito do real, que atribuímos ao romance, se deve não apenas à relação que o gênero estabelece com os aspectos da vida, mas principalmente à coerência na organização interna dos elementos que o compõem. Dentre estes elementos encontra-se a particularização do espaço. Este, que na prosa de ficção anterior ao romance servia apenas para ambientar um enredo episódico, passa a ser condição atuante na organização interna da obra criando, juntamente com os outros elementos, uma realidade única. De acordo com Vasconcelos, esta impressão de verdade não está “...num estilo particular, ou na descrição de pormenores e detalhes..."240, como observamos em Pamela, onde o espaço não é descrito de forma minuciosa, mas “...nasce muito mais da articulação coerente dos materiais no interior dos textos do que de seu caráter documentário ou das suas referências ao mundo exterior."241

Segundo Ian Watt, em Richardson, esta representação do real é moldada de modo a oferecer ao leitor “... a fuller and more convincing presentation of the inner lives of his characters and of the complexities of their personal relationships..." ${ }^{242}$ Assim sendo, se considerarmos que escritores modernos como James Joyce e Virginia Woolf procuravam explorar os estados de consciência da mente do homem comum, podemos dizer que esse interesse intrínseco do romance já pode ser encontrado nos romances richardsonianos. Através das técnicas utilizadas pelo escritor, como, por exemplo, o uso de uma narradora que

\footnotetext{
${ }^{240}$ Id., ibid., p. 39.

${ }^{241}$ VASCONCELOS, S. G. Dez Lições sobre o Romance Inglês do Século XVIII. São Paulo, Boitempo, 2002. p. 30 .

${ }^{242}$ WATT, I. The Rise of the Novel: Studies in Defoe, Richardson and Fielding. London, Pimlico, 2000. pp. 200-201.
} 
relata sua própria história de vida em uma linguagem simples e cotidiana carregada de sentimento, da forma epistolar, da imediação da escrita, da ação do tempo sobre as personagens e da particularização do espaço, sua narrativa buscava proporcionar ao leitor um mergulho na vida interior das personagens, seus sentimentos e pensamentos, suas angústias e alegrias. Ian Watt, em seu estudo sobre o surgimento do romance, afirma: "This direction [the direction of Richardson's narrative] is towards the delineation of the domestic life and the private experience of the characters who belong to it: the two go together - we get inside their minds as well as inside their houses."243

Do mesmo modo, foi também Richardson que, atribuindo grande importância ao closet ou espaço de recolhimento, ressaltou o desejo feminino de ter um espaço íntimo em que pudesse fruir a vida livremente ou se isolar dos ataques à constituição de sua individualidade, antecipando os primeiros desejos de afirmação da sua condição feminina e de sua emancipação como indivíduo co-participante nos movimentos sociais que compõem a vida, simbolizados posteriormente pelo espaço privado e pela garantia de independência na autonomia financeira professados por Woolf.

A partir da análise do romance, observamos que, em Pamela, o espaço não é um mero cenário para o desenrolar da narrativa, mas é determinante do modo de agir das personagens que, por sua vez, atuam sobre ele modificando-o. Como pudemos notar, o hábito da visitação entre os membros da gentry e da afluente classe média resultou na necessidade da criação de espaços privados dentro e fora da casa. Além disso, uma nova compreensão das funções do homem e da mulher dentro de um novo modelo de vida trouxe a divisão entre os espaços público e privado, e o conseqüente estabelecimento do domínio feminino sobre a esfera privada e do domínio masculino sobre o âmbito público da vida. De tal forma, de acordo com o modo de pensar que vigorava no século XVIII, para a mulher ficou reservado o mundo doméstico, da reflexão e da observação, e para o homem, o mundo da sobrevivência, da ação e da força.

Em um mundo em que os homens se compreendem e se relacionam a partir de posições sociais, políticas e econômicas definidas, o espaço não é um palco para o desenvolvimento das relações humanas, mas sim um elemento inerente a elas que lhes confere forma e significado. Deste modo, o relacionamento entre Pamela e Mr B. é pautado por uma compreensão hierárquica do mundo. $\mathrm{O}$ entendimento que ambos têm de si mesmos e do outro se dá a partir da estrutura social à qual pertencem e do espaço em que estão

\footnotetext{
${ }^{243}$ Id., ibid., p. 175.
} 
inseridos, que se caracteriza dentro do romance pelo espaço das duas mansões em que se desenrola a narrativa: a mansão de Bedfordshire, onde observamos uma ênfase no espaço de recolhimento e introspecção, e a mansão de Lincolnshire, onde o espaço externo, representado pelos jardins e pelo entorno da propriedade, ganha vigor caracterizando-se como o espaço da realização das ações. Podemos perceber no romance a estreita relação que se estabelece entre as personagens e a ocupação e uso dos espaços da casa. Nessa interação revela-se a lógica racional vigente no século XVIII, que pregava a união da ação e da reflexão na constituição da vida e das relações humanas dando forma a um mundo racional.

Para concluir este estudo, faremos menção ao texto In Praise of Richardson, escrito por Denis Diderot em 1761 para celebrar a morte do romancista inglês. Neste ensaio, Diderot mostra que a novidade da ficção de Samuel Richardson consiste em permitir que o leitor penetre de maneira profunda o vasto mundo de suas personagens. A genialidade de Richardson está na criação de uma ficção fortemente ancorada na realidade. Esta expressão do mundo real na literatura é tão forte para Diderot que lhe permite identificar traços das personagens richardsonianas nas pessoas comuns. Além disso, ele afirma que as paixões, problemas e aflições das personagens criadas por Richardson são também as suas, pois são as de todos os homens. Para Diderot, “...he [Richardson] shows me the general course of life as I experience it." 244

Segundo seu entendimento, as críticas dirigidas a Richardson, de que seus romances são longos e de leitura difícil e morosa, são infundadas, ou se devem à frivolidade dos homens de seu tempo. A humanidade aprenderia muito sobre o bem e a virtude com os romances richardsonianos. Ele escreve para o homem solitário e tranqüilo que reconhece a futilidade das distrações mundanas e se regozija com as emoções experimentadas durante os momentos reservados à introspecção.

Diante da perda de Richardson, Diderot diz: "Richardson is no more. What a loss for letters and for humanity!",245 e chega a exclamar: "Divine Richardson!", referindo-se à sua capacidade de arrancar emoções reais de seus leitores.

Nos dias de hoje este ensaio é visto com cautela, uma vez que é evidente um engrandecimento do talento do escritor inglês. De qualquer modo, certamente ficamos marcados pela leitura deste elogio a Samuel Richardson. Sua importância para a literatura do século XVIII e para o desenvolvimento da tradição literária não pode ser negada, e revela de

\footnotetext{
${ }^{244}$ DIDEROT, D. "In Praise of Richardson". In: DIDEROT, D. Selected Writings on Art and Literature. London, Penguin, 1994. p 83.

${ }^{245}$ Id., ibid., p. 92.
} 
forma contundente a forte emoção do filósofo e escritor francês diante de uma nova forma literária que surgia na Inglaterra como tentativa de responder às demandas que se impunham na estruturação de um novo modo de vida.

Terminamos este estudo com a exaltação de Diderot às qualidades deste escritor, cujo sucesso alcançado na época certamente revela um grande talento literário:

"O, Richardson! I will dare to say that the truest piece of history is full of lies, and that your novel is full of truths. History portrays a few individuals, you portray the human race; history ascribes to a few individuals what they have neither said or done; everything you ascribe to man he has said and done; history covers only a portion of time, a point on the surface of the globe; you have embraced all times and all places. The human heart, which was, is, and always will be the same, is the model from which you copy. $" 246$

${ }^{246}$ Id.,ibid., p. 90. 


\title{
APÊNDICE I: CARTA XV
}

\author{
“LETTER XV
}

My dear Mother,

I broke off abruptly my last letter; for I feared he was coming; and so it happened. I put the letter into my bosom, and took up my work, which lay by me; but I had so little of the artful, as he called it, that I looked as confused, as if I had been doing some great harm.

'Sit still, Pamela,' said he, 'and go on with your work, for all me. You don't tell me I am welcome home after my journey to Lincolnshire.' 'It would be hard, sir,' said I, 'if you were not always welcome to your honour's own home.'

I would have gone; but he said, 'Don't run away, I tell you. I have a word or two to say to you.' O how my heart fluttered! 'When I was a little kind to you,' said he, 'in the summerhouse, and you behaved so foolishly upon it, as if I had intended to do you great harm, did I not tell you, you should take no notice of what passed to any creature? And yet you have made a common talk of the matter, not considering either my reputation, or your own.' 'I made a common talk of it, sir!' said I: 'I have nobody to talk to, hardly -'

He interrupted me, 'Hardly! you little equivocator! what do you mean by hardly? Let me ask you, Have you not told Mrs Jervis for one?' 'Pray your honour,' said I, all in agitation, 'let me go down; for it is not for me to hold an argument with your honour.' 'Equivocator, again!' and took my hand, 'why do you talk of an argument? Is it holding an argument with me, to answer a plain question? Answer me to what I ask,' 'O good sir,' said I, 'let me beg you will not urge me further, for fear I forget myself again, and be saucy.'

'Answer me then, I bid you, Have you not told Mrs Jervis? It will be saucy in you, if you don't directly answer my question.' 'Sir,' said I (and fain would have pulled my hand from him), 'perhaps I should be for answering you by another question, and that would not become me.' 'What is it you would say?' replied he, 'speak out.'

'Then, sir,' said I, 'why should your honour be so angry I should tell Mrs Jervis, or any body else, what passed, if you intended no harm?'

'Well said, pretty innocent and artless! as Mrs Jervis calls you,' said he; 'and is it thus, insolent as you are! you taunt and retort upon me! But still I will be answered directly to my question.' 'Why then, sir,' said I, 'I will not tell a lye for the world: I did tell Mrs Jervis; for my heart was almost broken; but I opened not my mouth to any other.' 'Very well, bold-face,' said he, 'and equivocator again! You did not open your mouth to any other; but did you not write to some other?' 'Why now, and please your honour,' said I, (for I was quite courageous just then) 'you could not have asked me this question, if you had not taken from me my letter to my father and mother, in which (I own it) I had broke my mind freely to them, and asked their advice, and poured forth my griefs!'

'And so I am to be exposed, am I,' said he, 'in my own house, and out of my house, to the whole world, by such a saucebox?' 'No, good sir,' said I, 'and I pray your honour not to be angry with me; it is not $I$ that expose you, if I say nothing but the truth.' He was then very angry, and called me assurance; and bid me remember to whom I was talking.

'Pray, sir,' said I, 'of whom can a poor girl take advice, if it must not be of her father and mother, and such a good woman as Mrs Jervis, who, for her sex-sake, should give it me when asked?' 'Insolence! he then called me, and stamped with his foot. I fell down on my knees, and said, 'For heaven's sake, your honour, pity a poor creature, that knows nothing, but how to cherish her virtue and good name: I have nothing else to trust to; and though poor and friendless here, yet I have always been taught to value honesty above my life.' 'Honesty, foolish girl!' said he. 'But is it not one part of honesty to be dutiful and grateful to your master?' 'Indeed, sir, said I, it is impossible I should be ungrateful to your honour, or disobedient, or deserve the names of boldface and insolent, which you are pleased to call me, 
but when your commands are contrary to that first duty, which shall ever be the principle of my life!'

He seemed to be moved, and rose up, and walked into the great chamber two or three turns, leaving me on my knees; and I threw my apron over my face, and laid my head on a chair, and cried as if my heart would break, but had no power to go from that place.

At last he came in again, but with mischief in his heart! and raising me up, he said, 'Rise, Pamela, rise; you are your own enemy. Your perverse folly will be your ruin: I am very much displeased with the freedoms you have taken with my name to my house-keeper, as also to your father and mother; and you may as well have real cause to take these freedoms with me, as to make my name suffer for imaginary ones.' And saying so, he lifted me up, and offered to set me on his knee.

O how I was terrified! I said, like as I had read in a book a night or two before,' 'Angels and saints, and all the host of heaven, defend me! And may I never survive one moment, that fatal one in which I shall forfeit my innocence!' 'Pretty fool!' said he, 'how will you forfeit your innocence, if you are obliged to yield to a force you cannot withstand? Be easy, for let the worst happen that can, you'll have the merit, and $I$ the blame; and it will be a good subject for letters to your father and mother, and a pretty tale moreover for Mrs Jervis.'

He then, though I struggled against him, kissed me, and said, 'Who ever blamed Lucretia? The shame lay on the ravisher only: and I am content to take all the blame upon myself; as I have already borne too great a share for what I have deserved.' 'May I,' said I, 'Lucretia like, justify myself by my death, if I am used barbarously?' 'O my good girl!' replied he, tauntingly, 'you are well read, I see; and we shall make out between us, before we have done, a pretty story for a romance.'

He then offered to kiss my neck. Indignation gave double strength, and I got from him by a sudden spring, and ran out of the room; and the door of the next chamber being open, I rushed into it, and threw-to the door, and it locked after me; but he followed me so close, he got hold of my gown, and tore a piece off, which hung without the door; for the key was on the inside.

I just remember I got into the room. I knew nothing further till afterwards, having fallen down in a fit; and there I lay, till he, as I suppose, looking through the key-hole, 'spied me upon the floor, and then he called Mrs Jervis, who, by his assistance, bursting open the door, he went away, seeing me coming to myself; and bid her say nothing of the matter, if she were wise.

Poor Mrs Jervis thought it was worse, and cried over me as if she was my mother; and I was two hours before I came to myself; and just as I got to my feet, he coming in, I fainted away again; and so he withdrew: But he staid in the next room to hinder any body from coming near us, that his vile proceedings might not be known.

Mrs Jervis gave me her smelling-bottle, and had cut my laces, and sat me in a great chair, and he called her to him: 'How is the girl?' said he: 'I never saw such a fool in my life. I did nothing at all to her.'

Mrs Jervis could not speak for crying. So he said, 'She has told you, it seems, that I was kind to her in the summer-house, although I assure you, I was quite innocent then as well as now, and I desire you to keep this matter to yourself, and let not my name be freely used.'

'O, sir,' said she, 'for your honour's sake, and for Christ's sake -' But he would not hear her, and said, 'For your own sake, I tell you, Mrs Jervis, say not a word more. I have done her no harm. And I will not have her stay in my house; prating, perverse fool, as she is! But since she is so apt to fall into fits, or at least to pretend to do so, prepare her to see me to-morrow after dinner, in my mother's closet, and do you be with her as a witness to what shall pass between us.'

And so he went out in a passion, and ordered his chariot to be got ready, and went a visiting somewhere."247

${ }^{247}$ RICHARDSON, S. Pamela; or Virtue Rewarded. London, Penguin, 1985. pp. 61-64. 


\title{
APÊNDICE II: CENA DO LAGO
}

\author{
“Past Eleven o'Clock
}

Mrs Jewkes is come up, and gone to bed; and bids me not stay long after her. O for a dead sleep for the treacherous brute! I never saw her so much in liquor, and that gives me hopes. I have tried again, and find I can get my head through the iron bars. I am now all prepared. I hope soon to hear her fast; and now I'll seal up these and my other papers, my last work, and to Providence commit the rest! Once more, God bless you both! And send us a happy meeting! If not here, in his heavenly kingdom! Amen.

$$
\begin{aligned}
& \text { THRUSDAY, FRIDAY, SATURDAY, SUNDAY, the } 28^{\text {th }}, 29^{\text {th }} \text {, } \\
& \qquad 30^{t h} \text {, and } 31^{\text {st }} \text { days of my distress }
\end{aligned}
$$

And distress indeed! For here I am still! And every thing has been worse and worse! O the unhappy Pamela! Without any hope left, and ruined in all my contrivances! But do you, my dear parents, rejoice with me, even in this low plunge o my distress; for your poor child has escaped from an enemy worse than any she ever met with; an enemy she never thought of before, and was hardly able to stand against: I mean the weakness and presumption, both in one, of her own mind! Which, had not the Divine Grace interposed, would have sunk her into everlasting perdition!

I will proceed, as I have opportunity, with my sad relation: for my pen and ink (in my now doubly-secured closet) is all I have to employ myself with: and indeed I have been so weak, that still yesterday evening, I have not been able to hold a pen.

I took with me but one shift, besides what I had on, and two handkerchiefs, and two caps, which my pocket held, (for it was not for me to encumber myself) and all my stock of money, which was but five or sic shillings, to set out for I knew not whither; and got out of the window, not without some difficulty, sticking a little at my shoulders and hips; but I was resolved to get out, if possible. The distance from the window to the leads was greater than I had imagined, and I was afraid I had sprained my ancle; and the distance form the leads to the ground, was still greater; but I got no hurt considerable enough to hinder me from pursuing my intentions. So, being now in the garden, I hid my papers under a rose-bush, and covered them over with mould, and there I hope they still lie. Then I hied away to the pond: the clock struck twelve, just as I got out; and it was dark misty night, and very cold; but I was not then sensible of it.

When I came to the pond-side I flung in my upper-coat, as I had designed, and my handkerchief, and a round-eared cap, with a knot pinned upon it; then ran to the door, and took the key out of my pocket, my poor heart beating all the time, as if it would have forced its way through my stays. But how miserably was I disappointed, when I found that my key would not open the lock! The wretch, as it proved, had taken off the old lock, and another was put on! I tried and tried before I was convinced it was so; but feeling about found a padlock on another part of the door; the how my heart sunk! I dropped down with grief and confusion, unable to stir for a while. But my terror soon awakened my resolution; for I knew that my attempt, if I escaped not, would be sufficient to give a pretence for the most outrageous insults from the woman; and for the cruellest treatment from my master; and to bring him down the sooner to put his horrid purposes in execution; I therefore was resolved, if possible, to get over the wall; but that being high, had no other hope to do it, than by help of the ledges of the door, which are very strong and thick. I clambered up, therefore, upon them, and upon the lock, which was a great wooden one; and reached the top of the door with my hands; which shut not close to the wall; and then, little thinking I could climb so well, I made shift to lay hold on the top of the wall with my hands: but, alas for me! nothing but ill luck! no escape for 
poor Pamela! The wall being old, the bricks I held by, gave way, just as I was taking a spring to get up; and down came I, and received such a blow upon my head, with one of the bricks, that it quite stunned me; and I broke my shins and my ancle besides, and beat off the heel of one of my shoes.

In this dreadful way, flat upon the ground, I lay, for I believe five or six minutes; and then trying to get up, I sunk down again two or three times. My left hip and shoulder were sadly bruised, and pained me much; and besides my head bled quite down into my neck, as I could feel, and aked grievously with the blow I had with the brick. Yet these hurts I valued not; but crept a good way upon my knees and hands, in search of a ladder I just recollected to have seen against the wall two days before, on which the gardener was nailing a nectarine branch, that was loosened from the wall: but no ladder could I find. What, now, thought I, must become of the miserable Pamela! Then I began to wish myself again in my closet, and to repent my attempt, which I now censured as rash; but that was because it did not succeed.

God forgive me! but a sad thought came just then into my head! I trembled to think of it! Indeed my apprehensions of the usage I should meet with, had like to have made me miserable for ever! O my dear, dear parents, forgive your poor child! But being then quite desperate, I crept along, till I could raise myself on my staggering feet; and away limped I! What to do, but to throw myself into the pond, and so put a period to all my terror in this world! But, oh! to find them infinitely aggravated in a miserable eternity! had I not by the Divine Grace been with-held.

As I have escaped this temptation, I will tell you my conflicts on this dreadful occasion, that the Divine mercies may be magnified in my deliverance; and in that I am yet on this side the dreadful gulph, from which there could have been no return.

It was well for me, as I have since thought, that I was so bruised as I was; for this made me the longer before I got to the water; and gave time for a little reflection, for a ray of grace to dart in upon my benighted mind; and so, when I came to the pond-side, I sat myself down on the sloping bank, and began to ponder my wretched condition; and thus I reasoned with myself:

Pause here a little, Pamela, on what thou art about, before thou takest the dreadful leap; and consider whether there be no way yet left, no hope, it not to escape from this wicked house, yet from the mischiefs threatened thee in it!

I then considered, and after I had cast about in my mind, every thing that could make me hope, saw no probability; a wicked woman, devoid of all compassion! a horrid abetter just arrived in this dreadful Colbrand! an angry and resenting master, who now hated me, and threatened me with the most dreadful evils! and that I should, in all probability, be soon deprived even of the opportunity I now had before me, to free myself from all their persecutions! What hast thou to do, distressed creature, said I to myself, but to throw thyself upon a merciful God, (who knows how innocently thou sufferest) to avoid the merciless wickedness of those who are determined on thy ruin?

And the, thought I (and O that thought was surely of the devil's instigation; for it was very soothing and powerful with me) these wicked wretches, who now have no remorse, no pity on me, will then be moved to lament their misdoings; and when they see the dead corpse of the miserable Pamela dragged out to these dewy banks, and lying breathless at their feet, they will find that remorse to soften their obdurate hearts, which, now, has no place in them! And my master, my angry master, will then forget his resentments and say, 'Alas!' and it may be, wring his hands. 'This is the unhappy Pamela! whom I have so causelessly persecuted and destroyed! Now do I see she preferred her honesty to her life. She, poor girl! was no hypocrite, no deceiver; but really was the innocent creature she pretended to be!'

Then, thought I, will he, perhaps, shed a few tears over the corpse of his persecuted servant; and, though he may give out, it was disappointment, and (in order to hide his own guilt) love for poor Mr Williams; yet will he be inwardly grieved, and order me a decent funeral, and save me, or rather this part of me, from the dreadful stake, and the highway internment: and the young men and maidens in my father's neighbourhood will pity poor Pamela! But yet I hope I shall not be the subject of their ballads and their elegies, but that my memory, for the sake of my dear father and mother, may quickly slide into oblivion! 
I was once rising, so indulgent was I to this sad way of thinking, to throw myself in: but again my bruises made me slow; and I thought, What art thou about to do, wretched Pamela? How knowest thou, though the prospect be all dark to thy short-sighted eye, what God may do for thee, even when all human means fail? God Almighty would not lay me under these sore afflictions, if he had not given me strength to grapple with them, if I will exert it as I ought: and who knows, but that the very presence I so much dread of my angry and designing master, (for he has had me in his power before, and yet I have escaped) may be better for me, than these persecuting emissaries of his, who, for his money, are true to their wicked trust, and are hardened by that, and a long habit of wickedness, against, compunction of heart? God can touch his heart in an instant: and if this should not be done, I can then put an end to my life by some other means, if I am so resolved.

But how do I know, thought I, on the other hand, that even these bruises and mains that I have got, while I pursued only the laudable escape I had meditated, may not have been the means of furnishing me with the kind opportunity I now have of surrendering up my life, spotless and unguilty, to that merciful Being who gave it!

But then recollecting, Who gave thee, said I to myself, presumptuous as thou art, a power over thy life? Who authorized thee to put an end to it? Is it not the weakness of thy mind that suggests to thee that there is no way to preserve it with honour? How knowest thou what purposes God may have to serve, by the trials with which thou art now exercised? Art thou to put a bound to the Divine Will, and to say, 'Thus much will I bear, and no more?' And wilt thou dare to say, That if the trial be augmented and continued, thou wilt sooner die than bear it? Was not Joseph's exaltation owing to his unjust imprisonment?

If, despairing of deliverance, I destroy myself, do I not in effect, question the power of the Almighty to deliver me? And shall I not, in that case, be guilty of a sin, which, as it admits not of repentance, cannot be hoped to be forgiven? And wilt thou, to shorten thy transitory griefs, heavy as they are, plunge both body and soul into everlasting misery! Hitherto, Pamela, thought I, thou art the innocent, the suffering Pamela; and wilt thou, to avoid thy sufferings, be the guilty aggressor? How do I know but that the Almighty may have permitted these sufferings as trials of my fortitude, and to make me, who perhaps have too much prided myself in a vain dependence on my own foolish contrivances, rely wholly on his grace and assistance?

Then again, thought I, wilt thou suffer in one moment, all the good lessons of thy poor honest parents, and the benefit of their example, (who have persisted in doing their duty with resignation to the Divine Will, amidst the extreme degrees of disappointment, poverty, and distress, and the persecutions of merciless creditors) to be thrown upon thee; and bring down, as in all probability this thy rashness will, their grey hairs with sorrow to the grave, when they shall understand, that their beloved daughter, slighting the tenders of Divine Grace, despairing of the mercies of a protecting God, has blemished, in this last act, a whole life, which those dear parents had hitherto approved and delighted in?

What then, presumptuous Pamela, dost thou here? thought I: quit with speed these perilous banks, and fly from these dashing waters, that seem in their meaning murmurs, this still night, to reproach thy rashness! Tempt not God's goodness on the mossy banks, which have been witnesses of thy guilty purpose; and while thou hast power left thee, avoid the temptation, lest thy grand enemy, now, by Divine Grace, repulsed, return to the assault with a force that thy weakness may not be able to resist! And lest thou in one rash moment destroy all the convictions, which now have awed thy rebellious mind into duty and resignation to the Divine Will!

And so saying, I arose; but was so stiff with my hurts, so cold with the dew of the night, and the wet grass on which I had sat, as also with the damps arising from so large a piece of water, that with great pain I got from this pond, which now I think of with terror; and bending my limping steps towards the house, took refuge in the corner of an out-house, where wood and coals are laid up for family use: there, behind a pile of fire-wood, I crept, and lay down, as you may imagine, with a heart just broken; and expecting to be soon found out by cruel keepers, and to be worse treated than ever I yet had been. 
This, my dear father and mother, is the issue of your poor Pamela's fruitless enterprise; and who knows, if I had got out at the back-door, whether I had been at all in a better case, moneyless, friendless, as I am, and in a strange place! But blame not your poor daughter too much: nay, if ever you see this miserable scribble, all bathed and blotted with my tears, let your pity get the better of your reprehension! But I know it will.

I must leave off for the present; for my strength and my will are at this time far unequal to each other. But yet I will add, that though I should have praised God for my deliverance, had I been freed from my wicked keepers, and my designing master; yet I have more abundant reason to praise him, that I have been delivered from a worse enemy - Myself! ${ }^{248}$

${ }^{248}$ RICHARDSON, 1985, pp. 209-214. 


\section{APÊNDICE III: ILUSTRACÕES DE PAMELA}

As seguintes ilustrações, feitas para o romance Pamela, foram selecionadas por fornecerem indícios sobre a organização e o uso dos espaços nas duas mansões em que se desenrola a narrativa: a mansão de Bedfordshire e a mansão de Lincolnshire. A maioria destas ilustrações foi produzida por Francis Hayman em conjunto com Hubert François Gravelot. Estes dois artistas produziram vinte e nove ilustrações para a edição de 1742 do romance, doze das quais foram feitas por Hayman e as restantes por Gravelot. A este último coube também a tarefa de transformá-las em gravuras. O trabalho de seleção das cenas e execução das gravuras foi supervisionado por Richardson, que desejava demonstrar e registrar as qualidades de beleza, refinamento e dignidade de Pamela. Além destas, algumas telas de Joseph Highmore são também apresentadas neste apêndice por mostrarem alguns dos espaços a que nos referimos durante a análise. Estas telas (num total de 12) buscavam recontar o enredo do romance e foram produzidas entre os anos de 1742 e 1745 sem o conhecimento de Richardson, mas foram por ele apreciadas por preservarem o espírito do romance e ilustrarem de modo fiel as personagens, a arquitetura e os costumes da época. ${ }^{249}$

${ }^{249}$ DUNCAN EAVES, T. C. "Graphic Illustration of the Novels of Samuel Richardson: 1740-1810". The Huntington Library Quarterly. University of California, v.14, n.4, ago. 1951. 


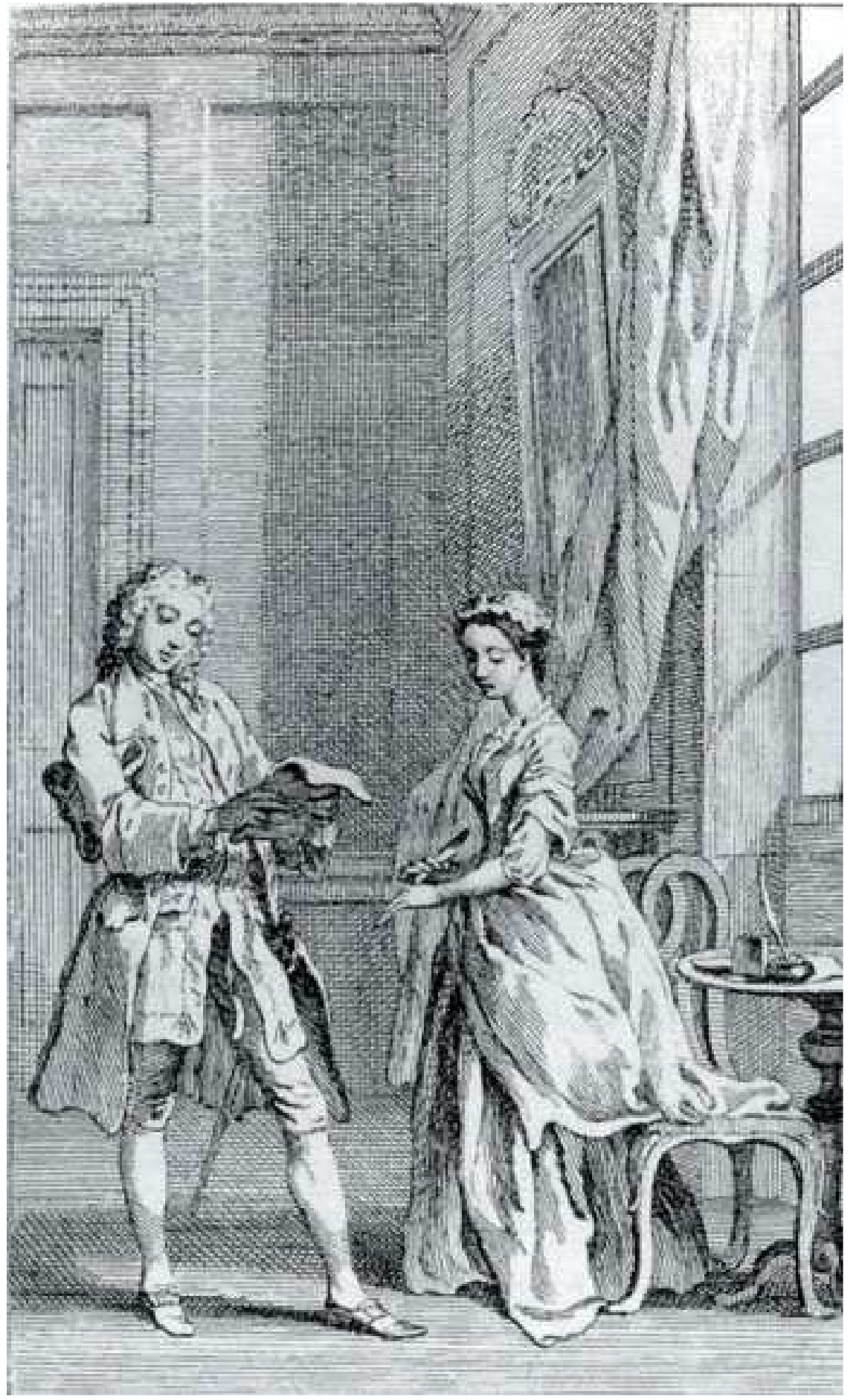

"Mr B. reading Pamela's letter". Ilustração de Hubert François Gravelot e Francis Hayman para Pamela, edição de 1742.

Nesta gravura vemos Mr B. em companhia da criada na mansão de Bedfordshire, lendo uma de suas cartas. Esta ilustração nos mostra o interior da casa, onde podemos ver parte da mobília e dos objetos de decoração, como a mesa, a cadeira, a cortina, e os apetrechos para a escrita.

Fonte: 〈http://en.wikipedia.org/wiki/Hubert_Francois_Gravelot>. Acesso em 10 julho 2009. 


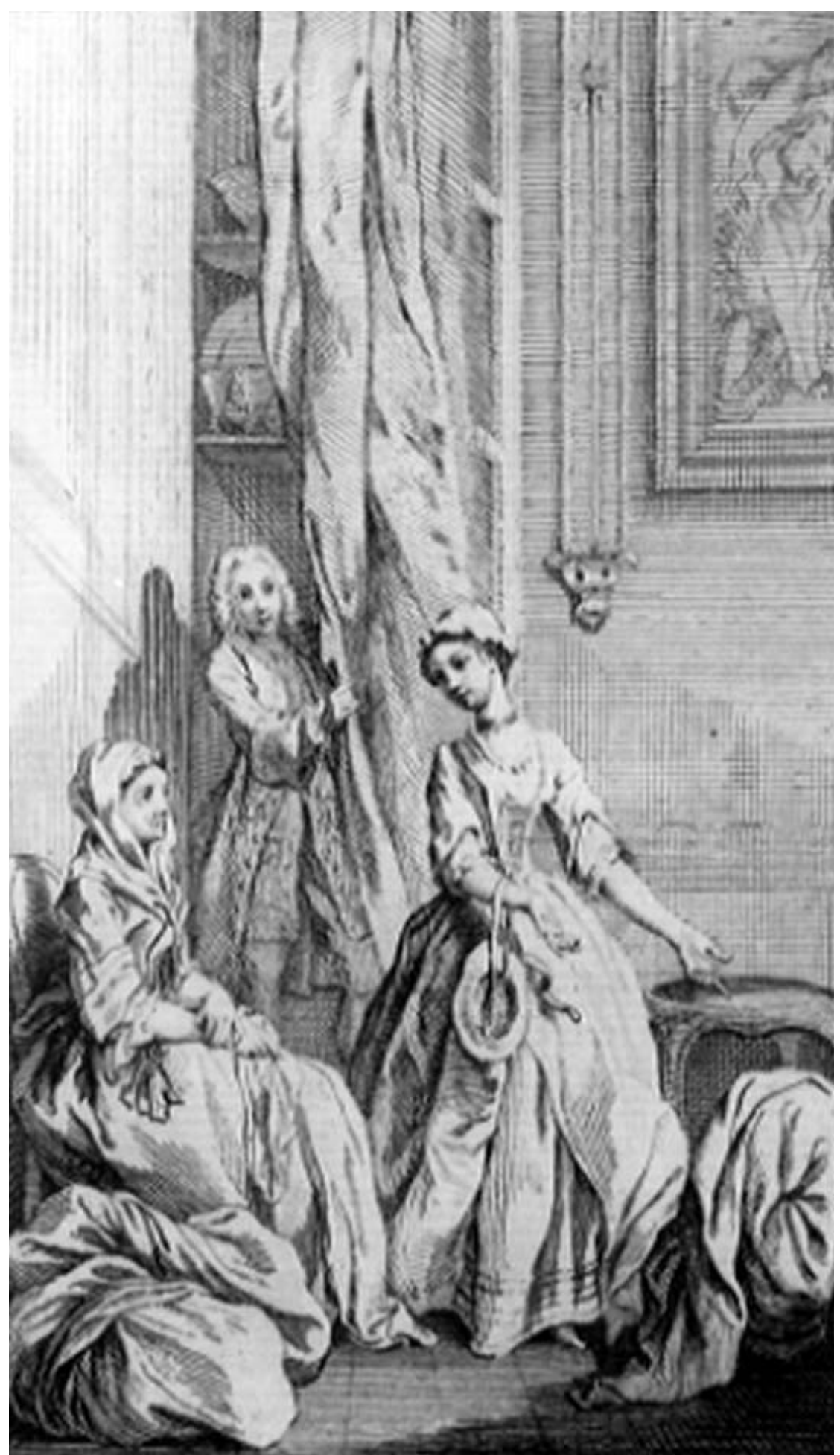

"Pamela revealing to Mrs Jervis her wishes to return home". Ilustração de Hubert François Gravelot e Francis Hayman para Pamela, edição de 1742.

Nesta gravura vemos Pamela conversando com a governanta da mansão de Bedfordshire, Mrs Jervis, com Mr B. ao fundo. Nesta cena, Pamela aponta seus fardos e revela à governanta sua intenção de voltar à casa dos pais. Aqui notamos o requinte da decoração desta primeira mansão, residência oficial de Mr B.

Fonte: <http://muse.jhu.edu/journals/eighteenth-century_life/v023/23.raynie.html>. Acesso em 23 julho 2009. 


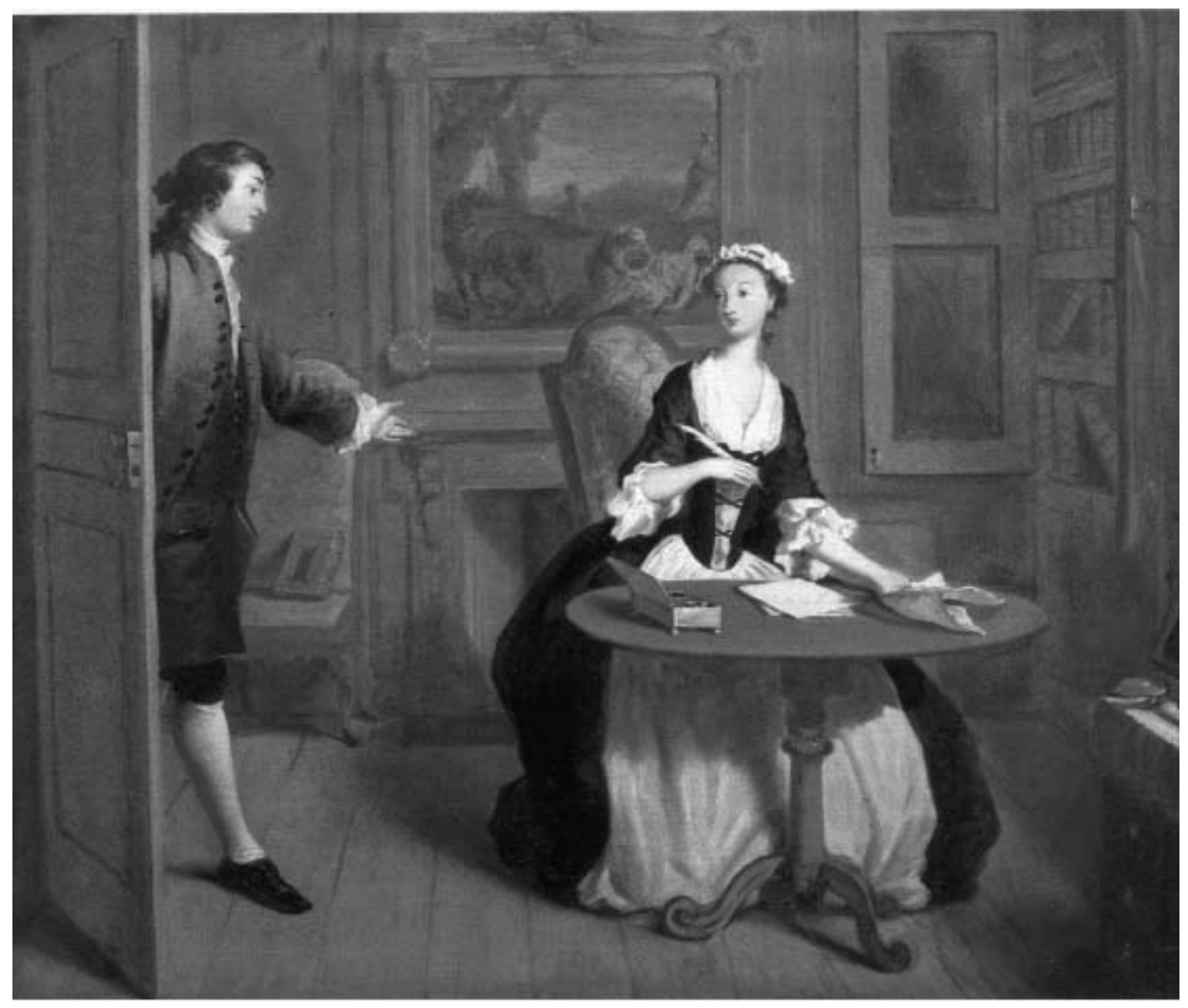

“Mr B. finds Pamela writing". Tela de Joseph Highmore, 1743-4. Parte da coleção da Tate Gallery, Londres.

Por esta tela de Highmore podemos notar o uso e alguns detalhes da decoração do closet. Observamos não só a mesa em que Pamela escreve suas cartas, mas também uma poltrona à esquerda, uma estante de livros à direita, além de uma tela sobre a lareira ao fundo. A existência de uma porta torna evidente a garantia de privacidade e isolamento deste aposento.

Fonte: Duncan Eaves, 1951, plate III. 


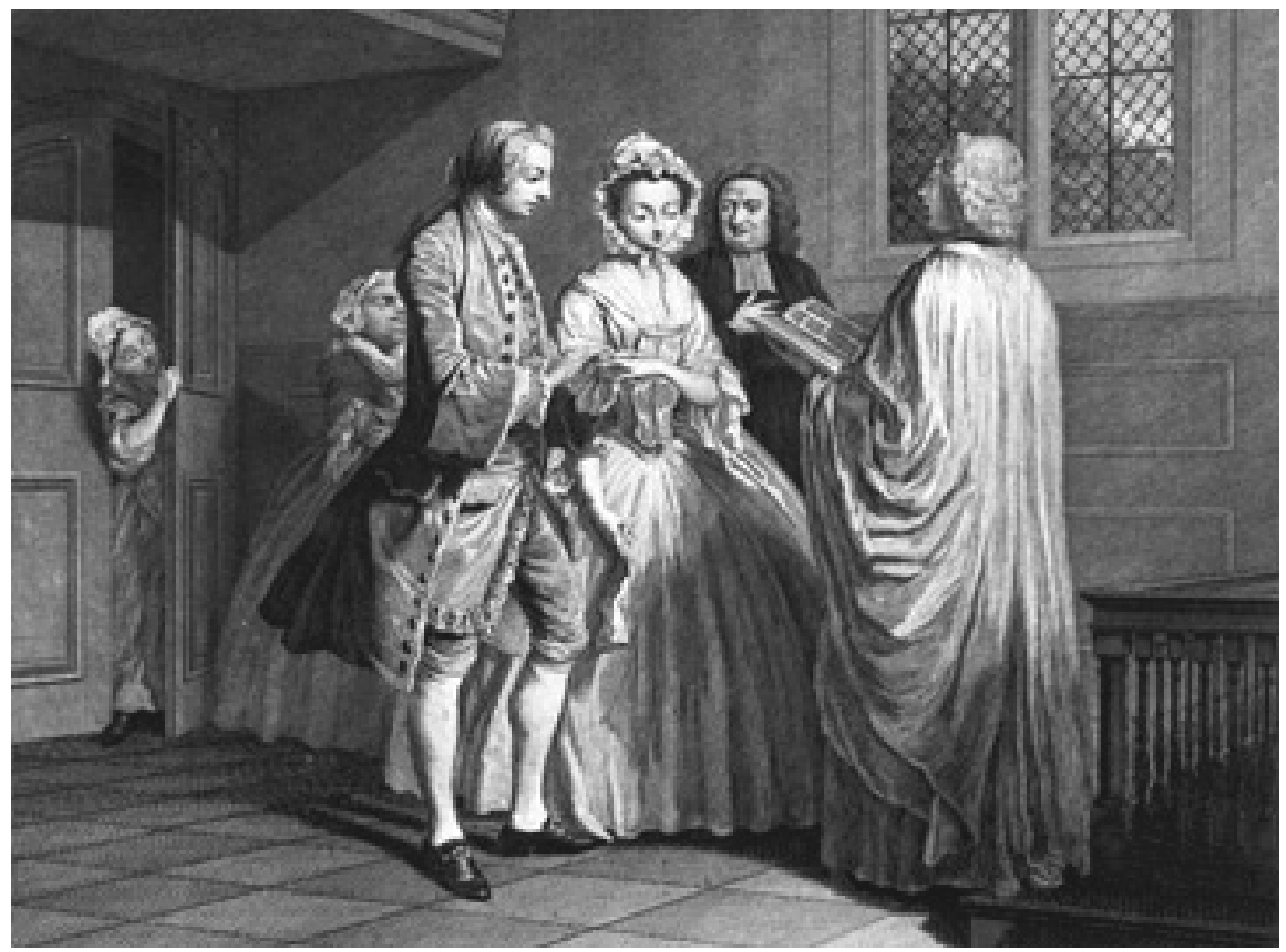

"Pamela is married". Gravura de L. Truchy elaborada a partir de tela de Joseph Highmore, 1743-4. Parte da coleção da Colonial Williamsburg Foundation.

Nesta ilustração vemos a capela em que se realiza o casamento de Pamela e Mr B. Esta é apenas uma das inúmeras construções que a mansão de Lincolnshire abriga em seus jardins. Como mencionamos na análise, esta capela sofre uma reforma antes do casamento, por ter sido utilizada como depósito durante muito tempo. Podemos observar a presença de uma janela de onde se pode enxergar um bosque.

Fonte:<http://www.history.org/History/teaching/enewsletter/volume7/images/mar/pamela_marriage_sm.jpg>. Acesso em 11 julho 2009. 


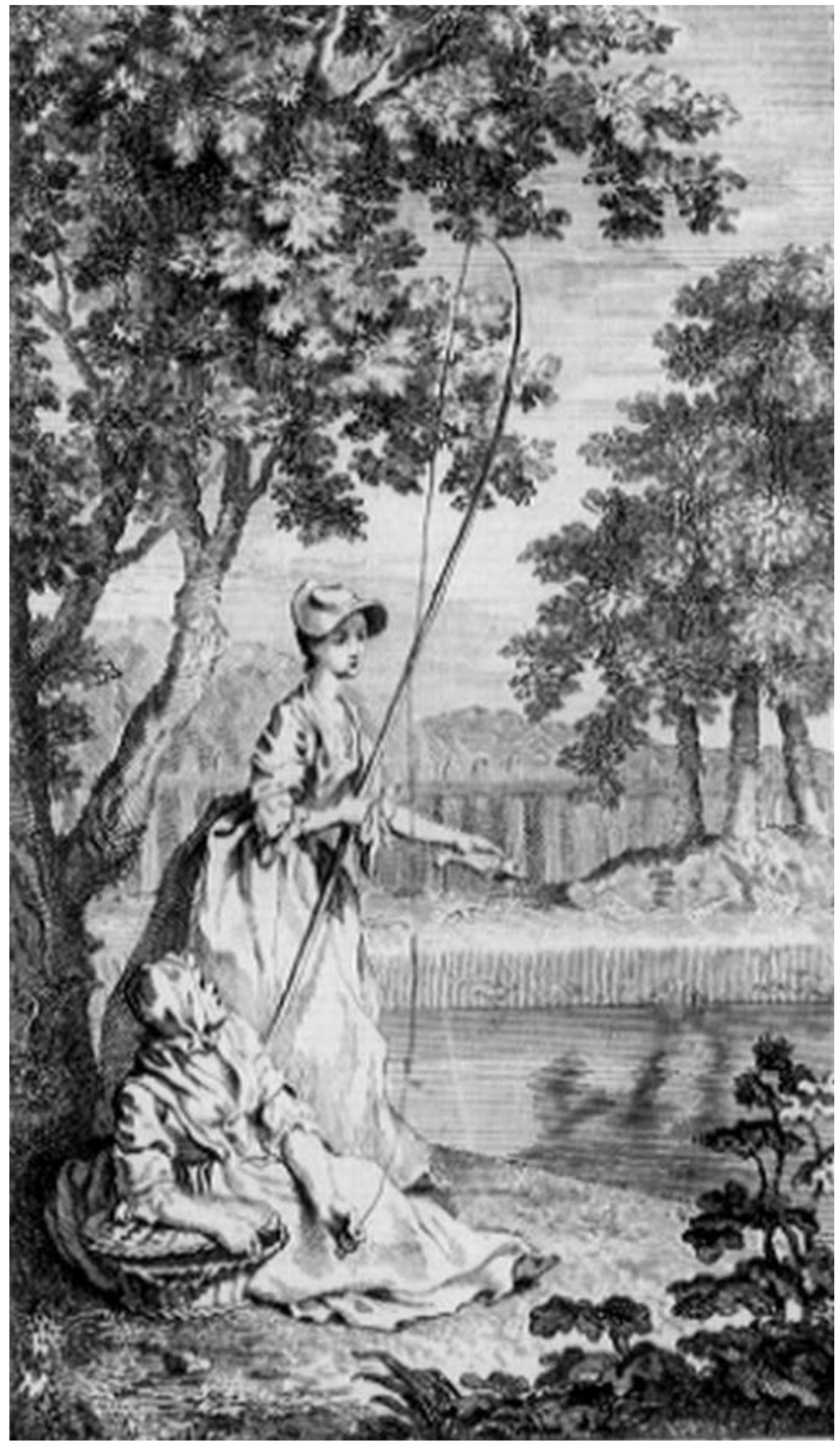

"Pamela throwing the carp into the stream". Ilustração de Hubert François Gravelot e Francis Hayman para Pamela, edição de 1742.

Nesta gravura Pamela pesca carpas em companhia de Mrs Jewkes, a governanta. Podemos observar o jardim nas proximidades do lago na mansão de Lincolnshire.

Fonte: <http://muse.jhu.edu/journals/eighteenth-century_life/v023/23.raynie.html>. Acesso em 23 julho 2009. 


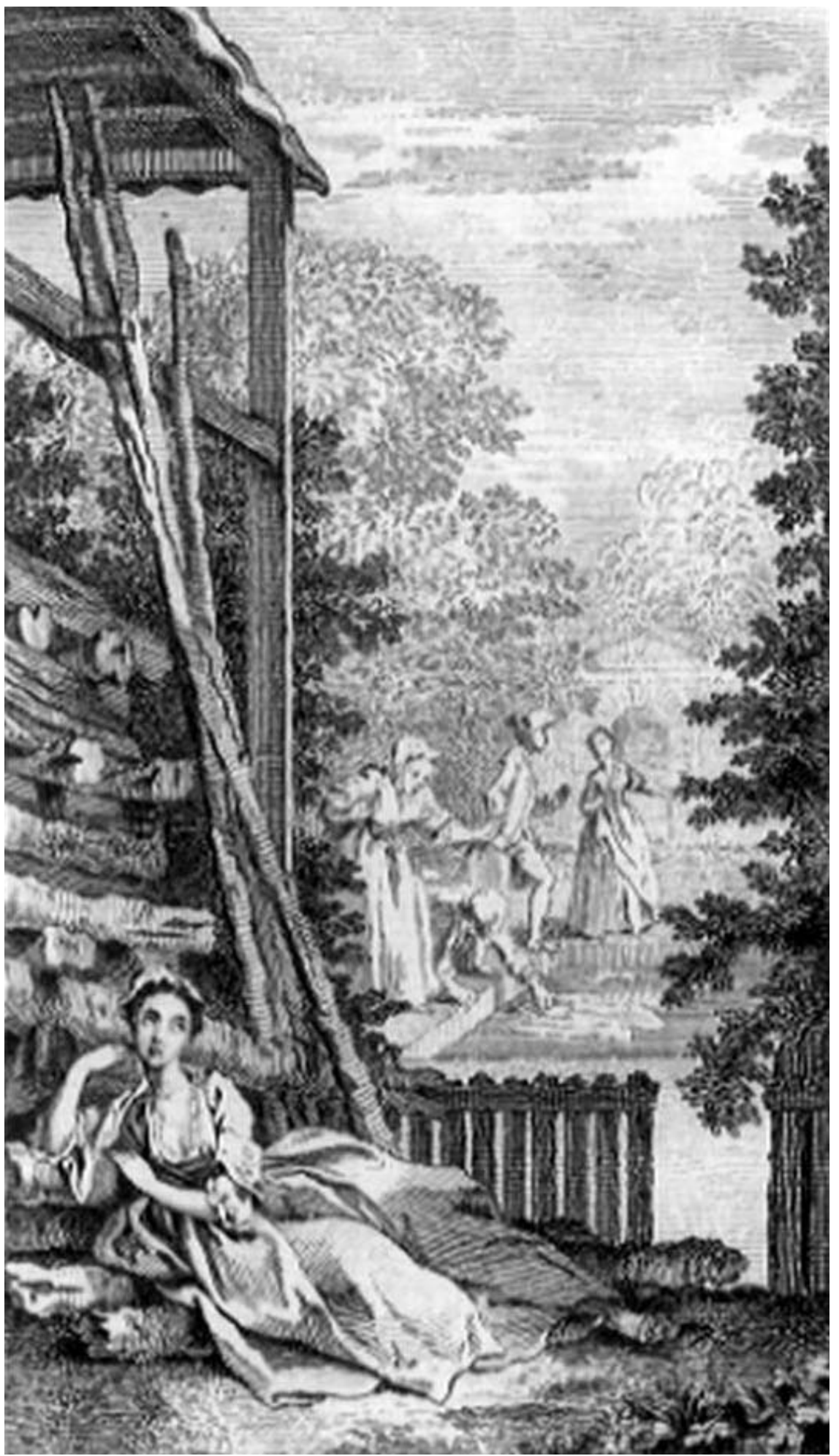

"Pamela taking refuge in the woodhouse after her attempted escape". Ilustração de Hubert François Gravelot e Francis Hayman para Pamela, edição de 1742.

Aqui temos novamente uma cena externa na mansão de Lincolnshire. Após a tentativa frustrada de fuga, Pamela se abriga em uma pequena construção próxima ao lago enquanto os empregados da casa procuram desesperadamente por ela. Esta figura nos mostra novamente o lago e o ambiente ao seu redor. Ao fundo vemos uma das inúmeras edificações do jardim.

Fonte: <http://muse.jhu.edu/journals/eighteenth-century_life/v023/23.raynie.html>. Acesso em 23 julho 2009. 


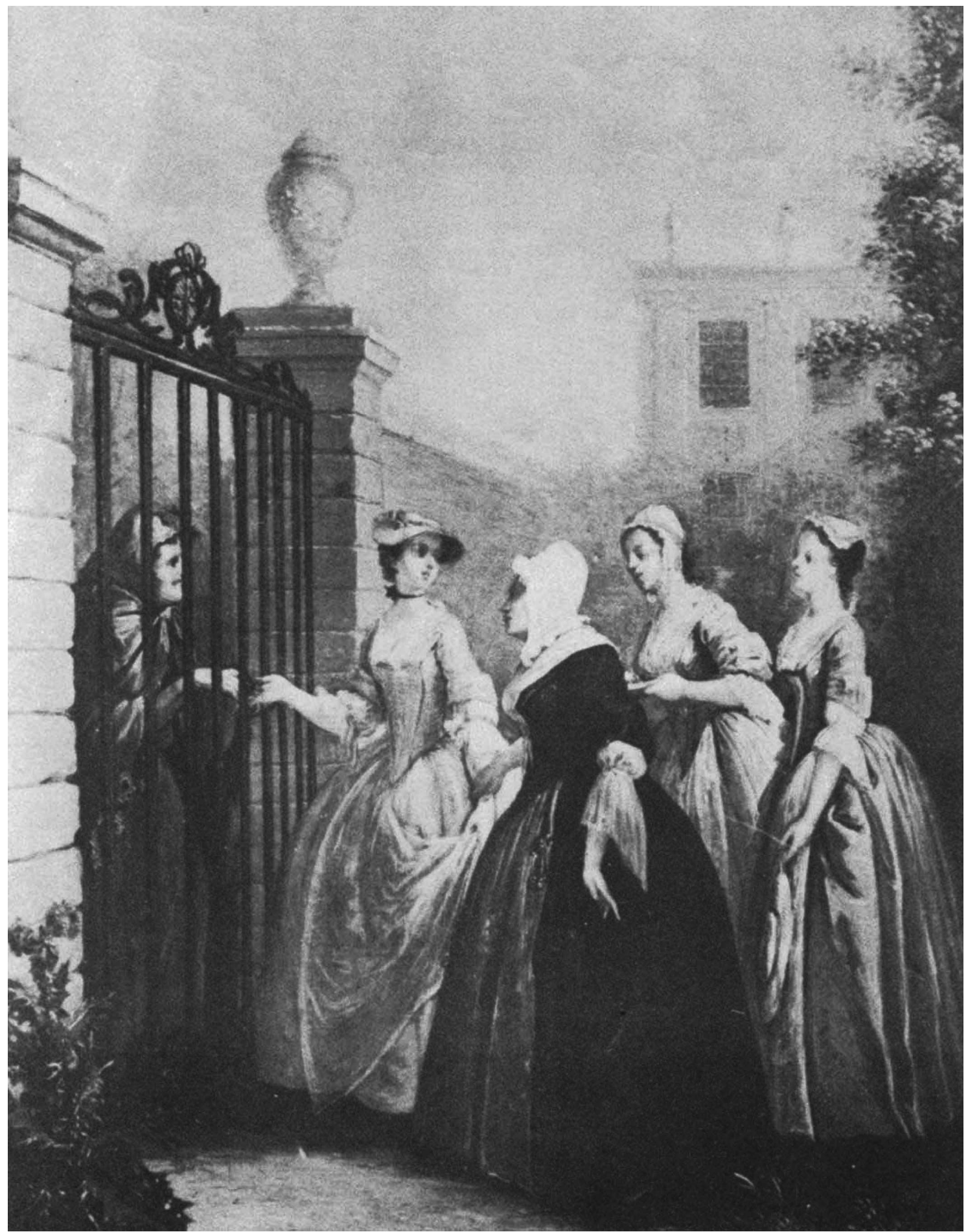

“Pamela and the fortune teller". Ilustração de Hubert François Gravelot e Francis Hayman para Pamela, edição de 1742.

Aqui temos novamente uma cena no exterior da mansão de Lincolnshire, quando Pamela conversa com a cigana e fica sabendo da intenção de Mr B. em propor-lhe um casamento falso. Pela ilustração podemos ver o muro que circunda o jardim e o portão que dá acesso a casa. Ao fundo vislumbramos o estilo arquitetônico da mansão.

Fonte: Duncan Eaves, 1951, plate II. 


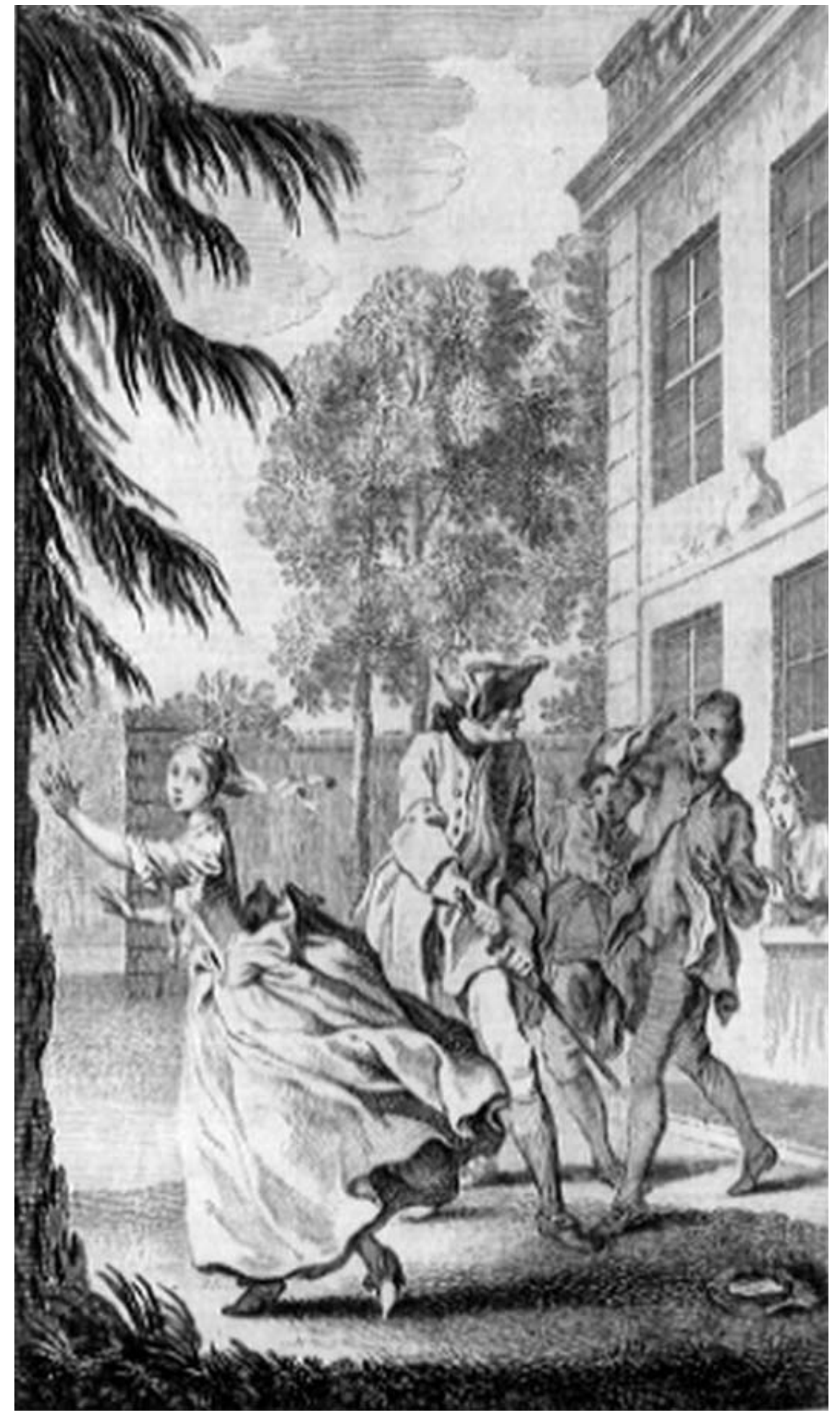

"Pamela fleeing from Lady Davers". Ilustração de Hubert François Gravelot e Francis Hayman para Pamela, edição de 1742 .

Novamente, uma cena externa na mansão de Lincolnshire. Aqui Pamela foge de Lady Davers, que vem à casa para exigir que seu irmão esqueça a criada. Por esta gravura podemos ter uma idéia mais precisa do estilo arquitetônico da casa e ao fundo podemos ver o muro que circunda os jardins.

Fonte: Duncan Eaves, 1951, plate I. 


\section{APÊNDICE IV: ILUSTRACÕES DE MANSÕES INGLESAS DA ÉPOCA}

A seguir apresentamos uma série de imagens que exemplificam o estilo arquitetônico, a decoração e a organização dos espaços interno e externo de algumas propriedades inglesas do final do século XVII e começo do século XVIII. Estas ilustrações foram escolhidas por demonstrarem certa semelhança com as mansões e os jardins retratados nas gravuras de Hayman e Gravelot, bem como nas telas de Highmore. A primeira página apresenta um mapa da Grã-Bretanha onde podemos ver a divisão da Inglaterra em condados. Em seguida, algumas plantas e perspectivas mostram vários exemplos do interior e de fachadas de diferentes mansões bem como dos jardins próximos à casa e os campos e bosques circundantes. Estas imagens foram incluídas por fornecerem uma base para a compreensão da organização, estrutura e dimensão destas propriedades inglesas. 


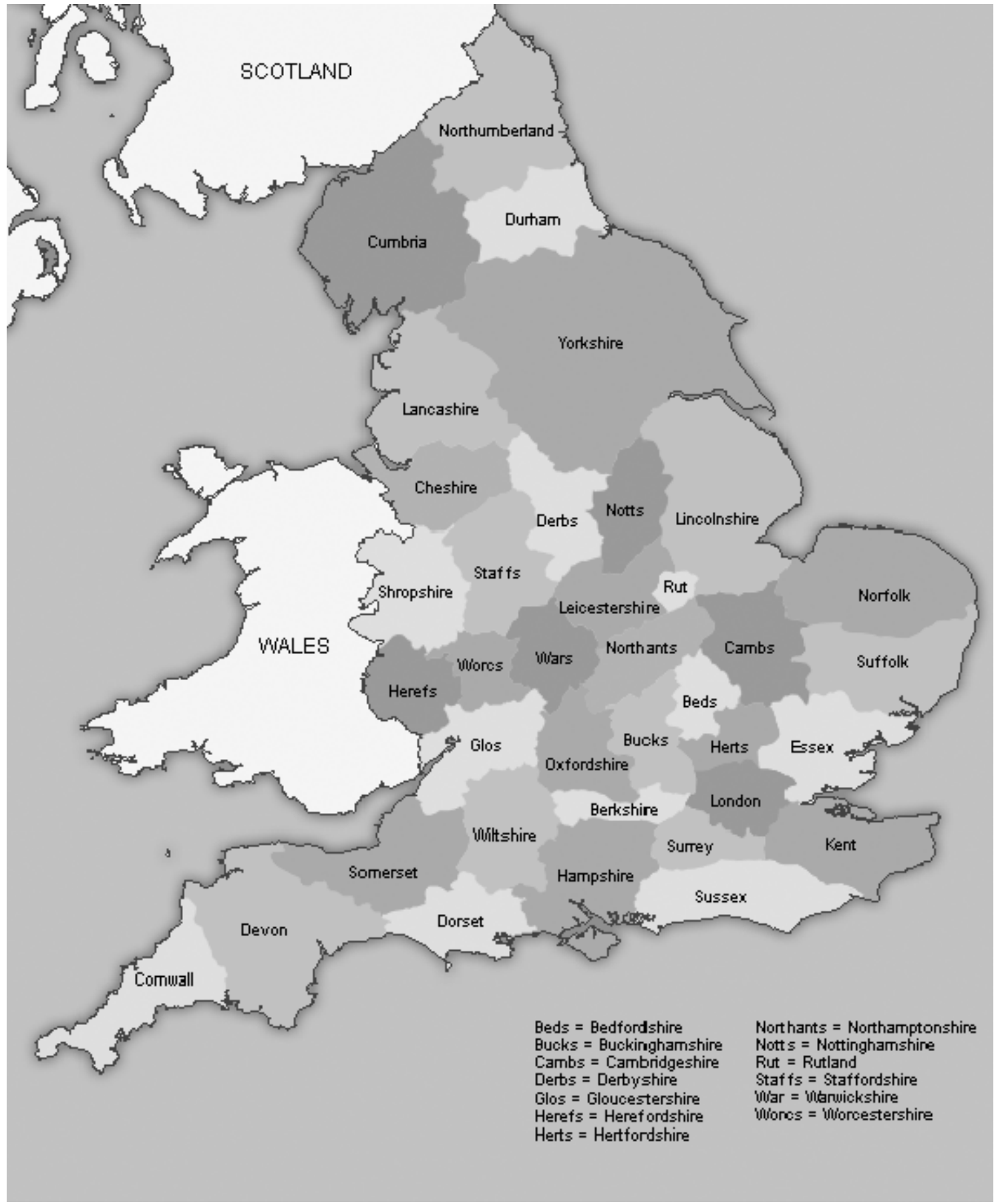

\section{Mapa da Grã-Bretanha com a subdivisão da Inglaterra em condados.}

Pelo mapa podemos notar que o condado de Bedfordshire está localizado no centro-sul, mais próximo a Londres, e o condado de Lincolnshire ao norte, logo acima de Cambridgeshire. O vilarejo de Stamford, mencionado no romance, não aparece no mapa, mas se localiza na parte sul deste condado. Fonte: <http://www.itraveluk.co.uk/maps/england>. Acesso em 23 julho 2009. 

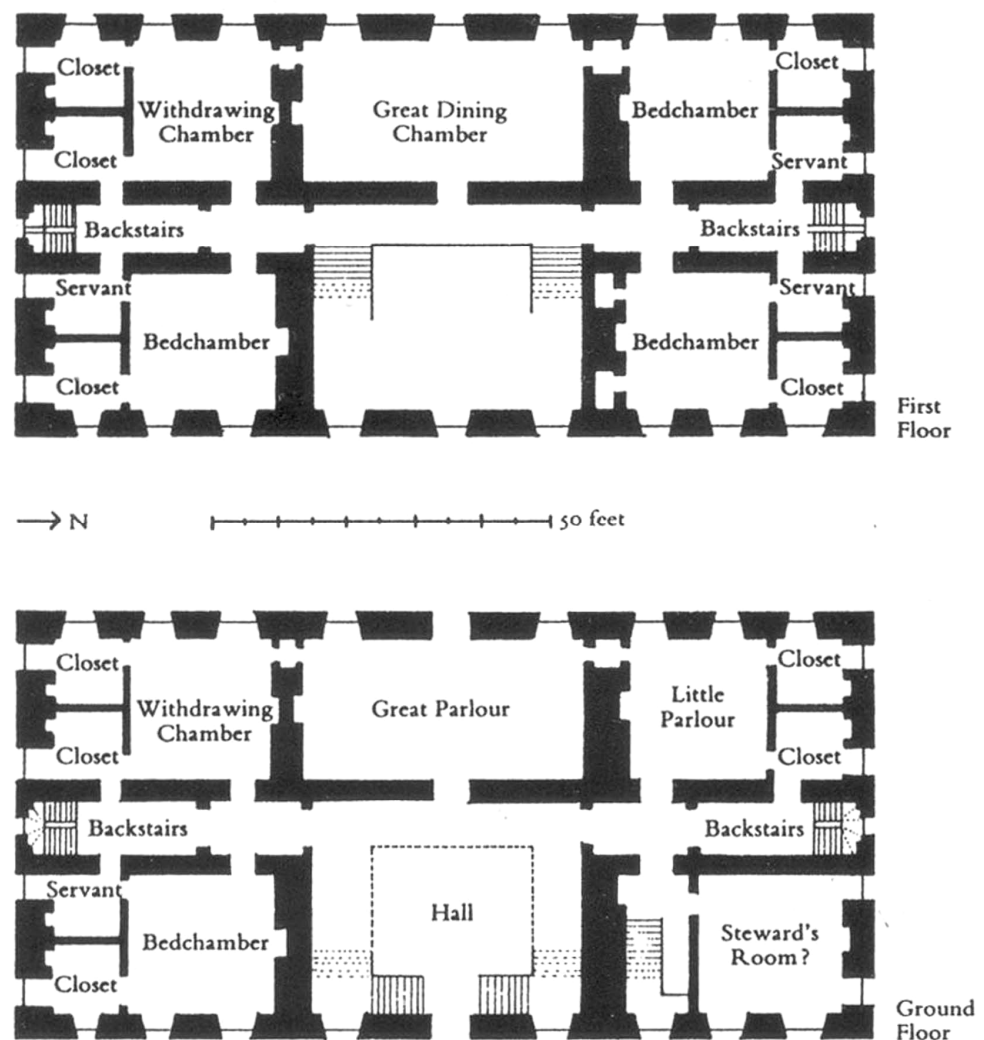

“Berkshire. Casa Coleshill, 1650".

Fonte: Steenbergen \& Reh, 2001, p. 252.

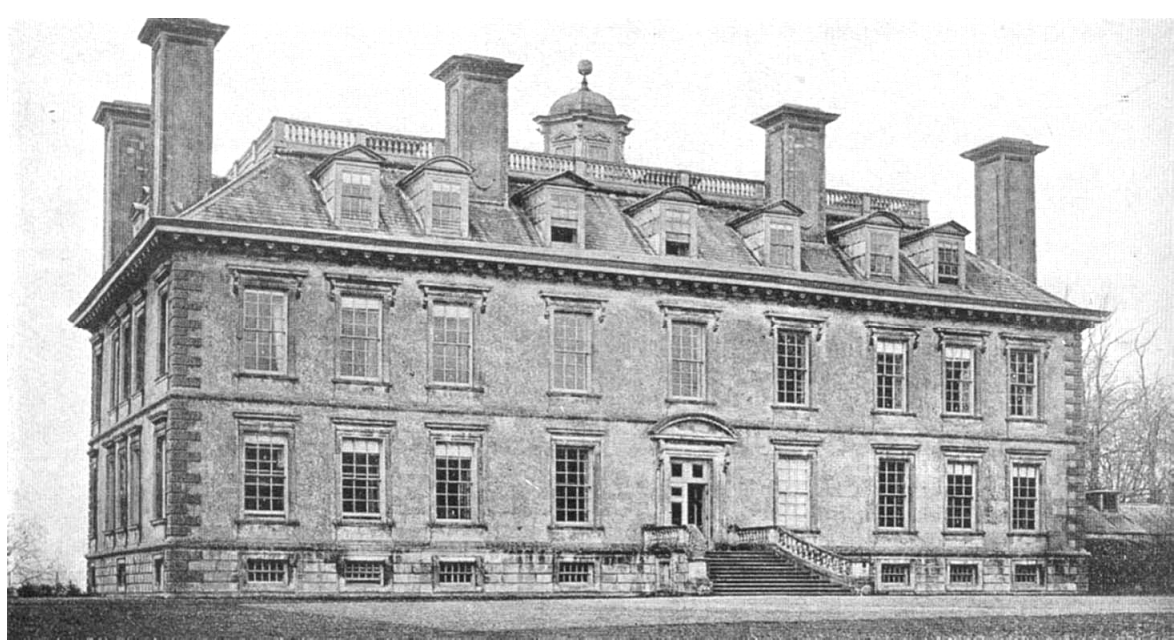

“Coleshill House, Berks: Entrance façade (AD 1650-64)”.

Imagens de uma mansão da segunda metade do século XVII localizada no condado de Berkshire. Pela planta podemos ver a distribuição dos cômodos internos da casa com a presença dos parlours, chambers e closets.

Fonte: Fletcher, 1956, p. 800. 


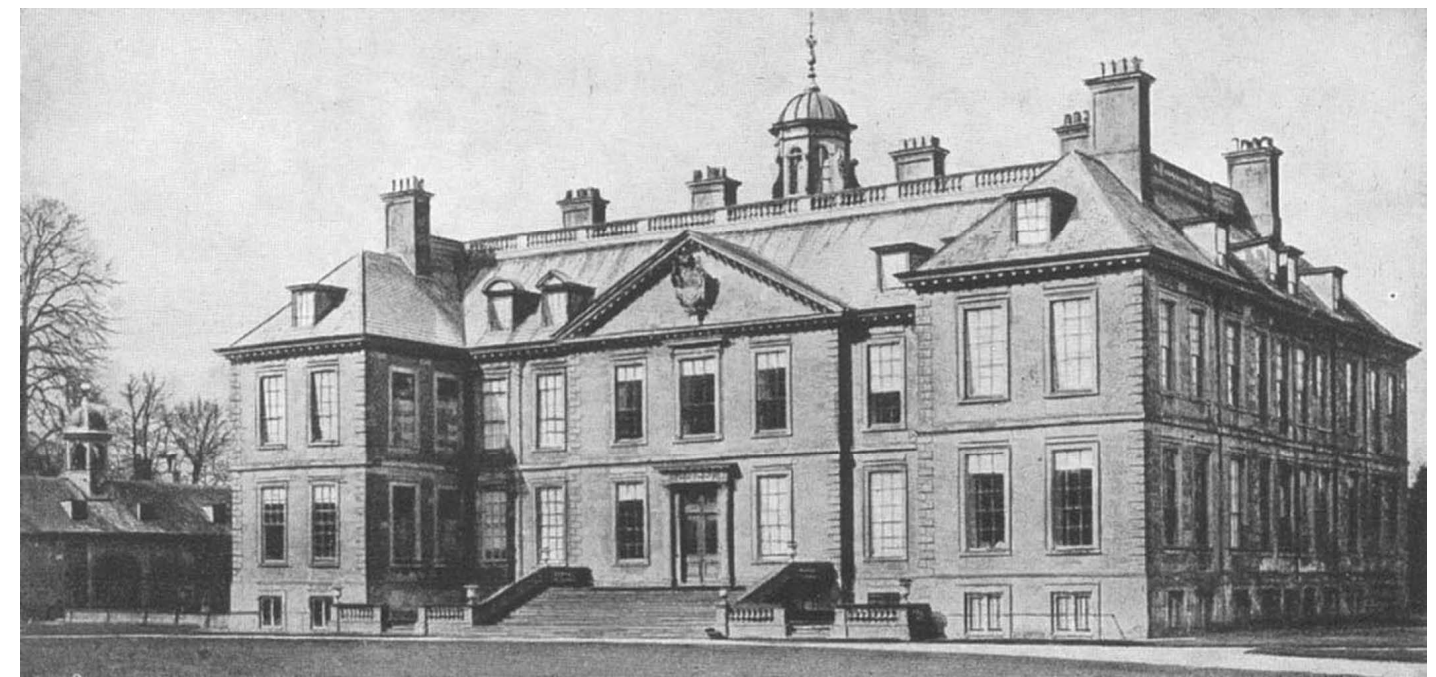

"Belton House, Lincs (AD 1689)".

Fonte: Fletcher, 1956, p. 817.

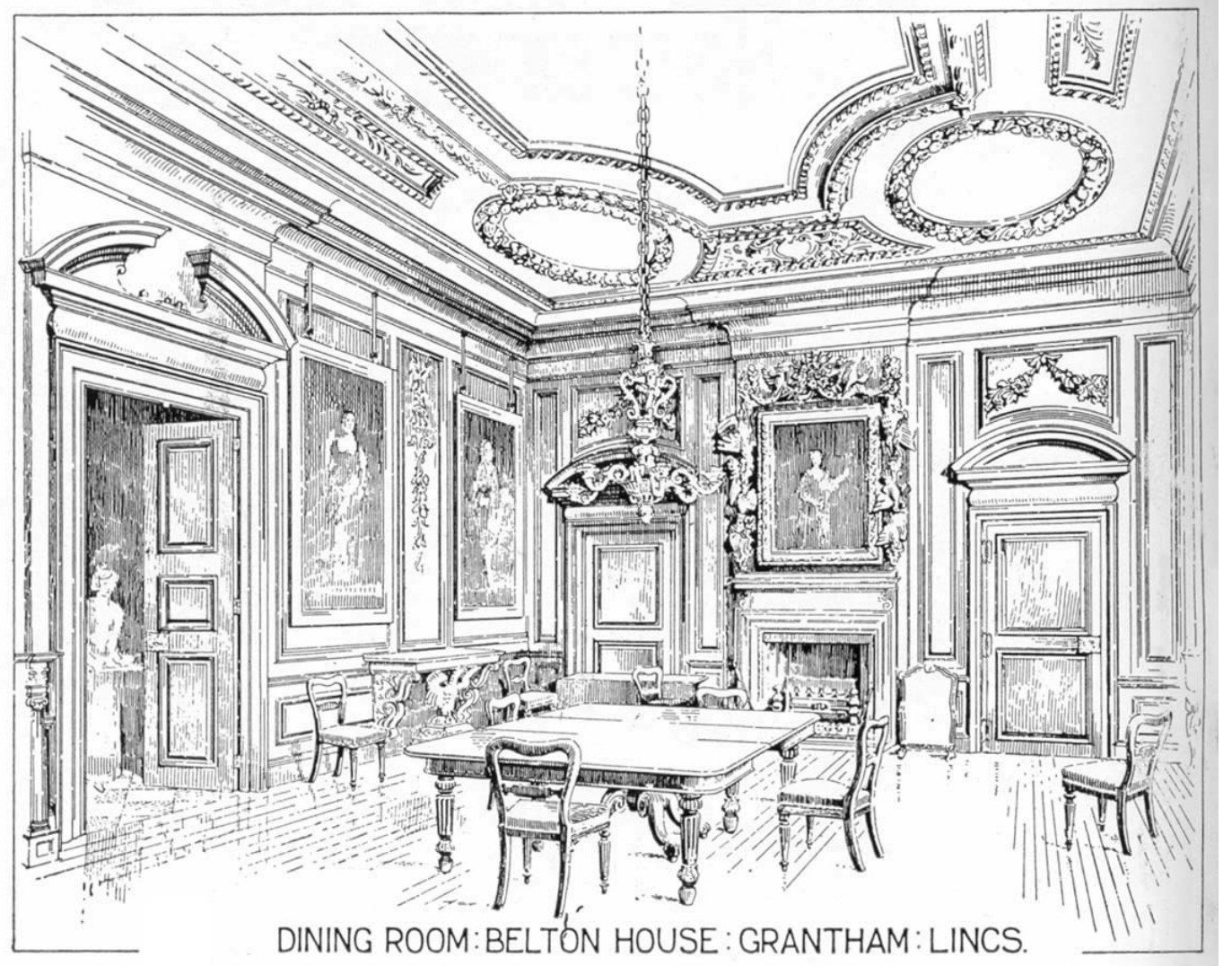

\section{"Dining room: Belton House: Grantham: Lincs".}

Imagens da fachada e de um ambiente interno de uma mansão inglesa construída na segunda metade do século XVII, localizada no condado de Lincolnshire. A perspectiva da sala de jantar mostra o grande requinte da decoração destas mansões inglesas.

Fonte: Fletcher, 1956, p. 822. 


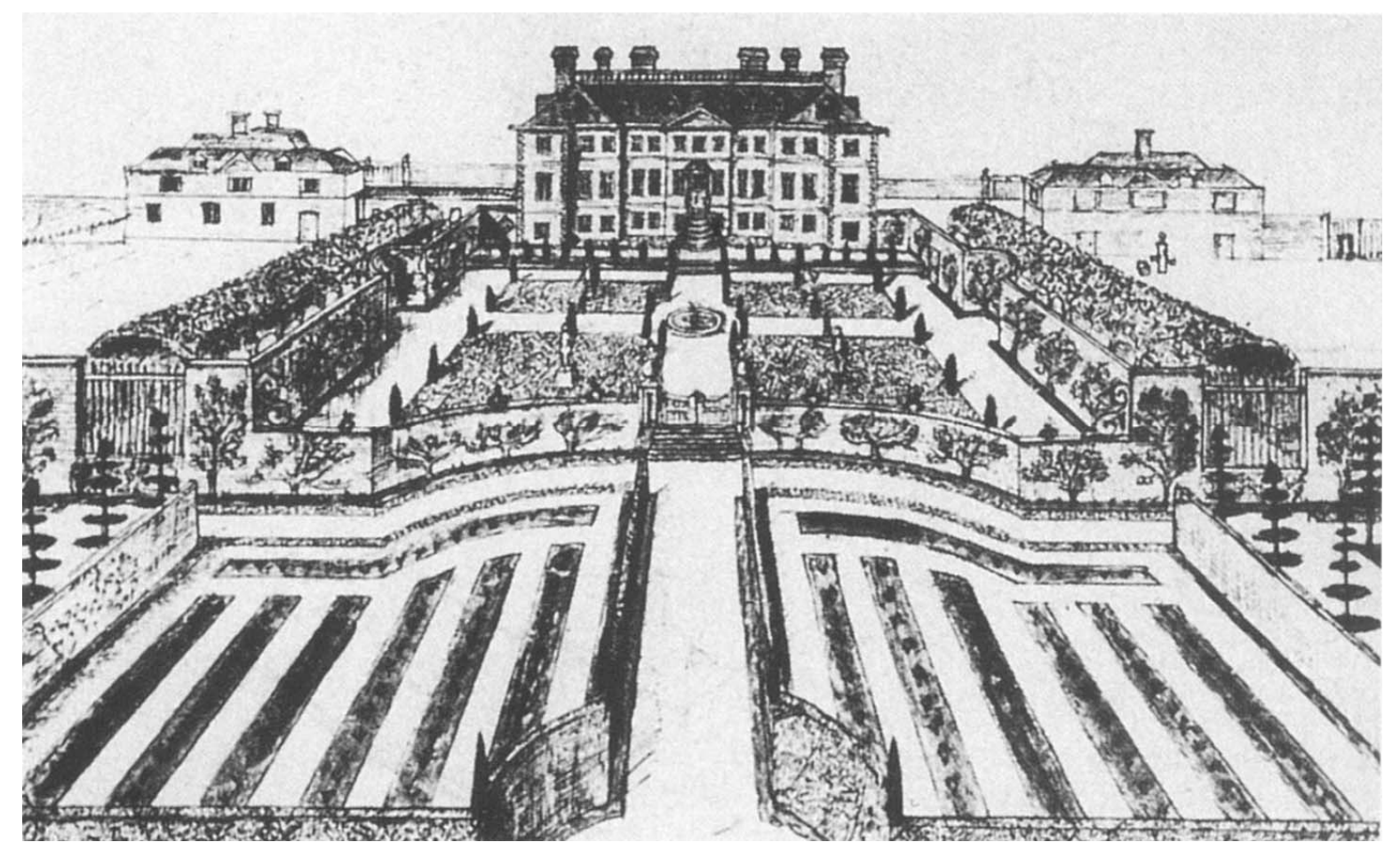

\section{“Stowe, Buckinghamshire. A casa do século XVII com o jardim na parte sul”.}

A propriedade de Stowe chegou às mãos da família Temple no século XVI, mas foi durante os séculos XVII e XVIII que a fortuna familiar permitiu ampliar a residência e embelezar os imensos jardins da propriedade rural. As transformações efetuadas no jardim durante o século XVIII fizeram de Stowe um dos exemplares mais importantes da arte paisagística inglesa. Esta imagem apresenta a mansão antes de sua ampliação. Os jardins estão configurados de maneira bastante formal, sendo delimitados por muros, com canteiros e caminhos organizados de modo regular.

Fonte: Steenbergen \& Reh, 2001, p. 282. 


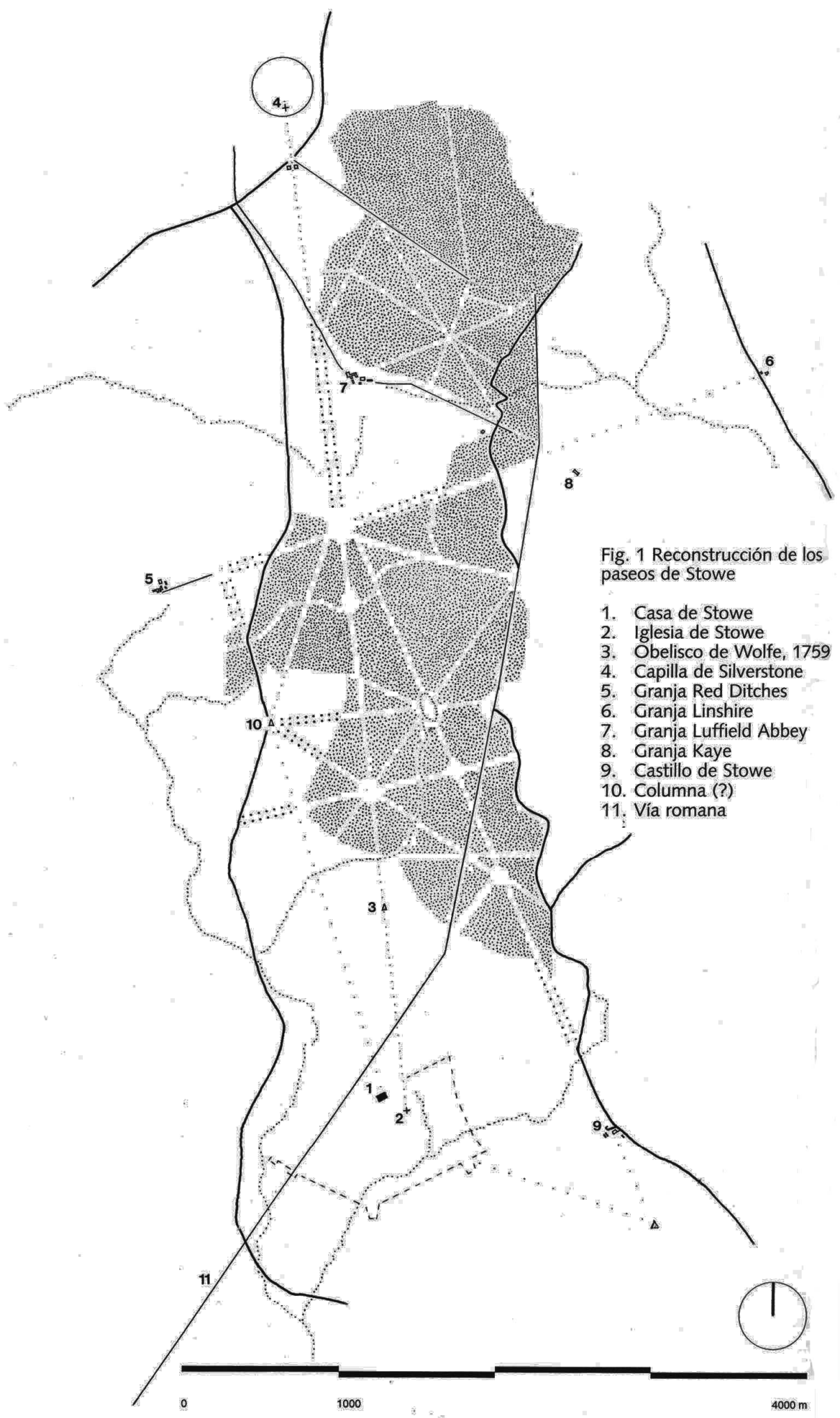

\section{“Reconstrução dos passeios de Stowe”.}

O desenho indica as principais construções e os imensos bosques de Stowe no final do século XVII. Mostra também as dimensões da propriedade, o que permite inferir a extensão dos jardins que faziam parte das mansões da aristocracia inglesa nos séculos XVII e XVIII. Fonte: Steenbergen \& Reh, 2001, p. 284. 


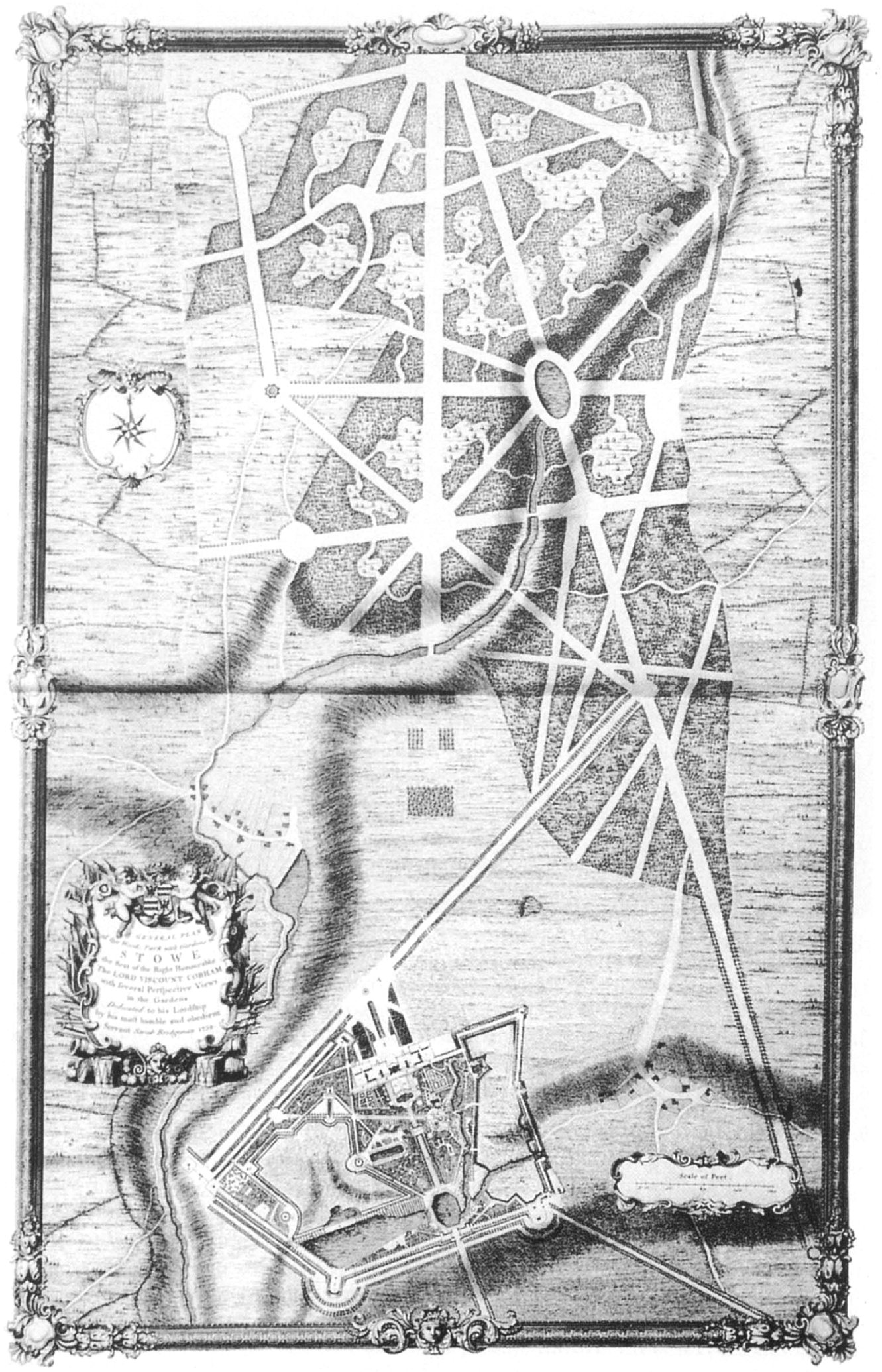

“Stowe: Plano geral. Desenho elaborado por Sarah Bridgeman, 1739”.

O desenvolvimento dos jardins de Stowe teve início com o trabalho de Charles Bridgeman e Vanbrugh a partir de 1713. Neste desenho podemos observar a casa e os jardins ao seu redor, além dos caminhos que levam ao bosque e às construções que se localizam na propriedade. Fonte: Steenbergen \& Reh, 2001, p. 287. 


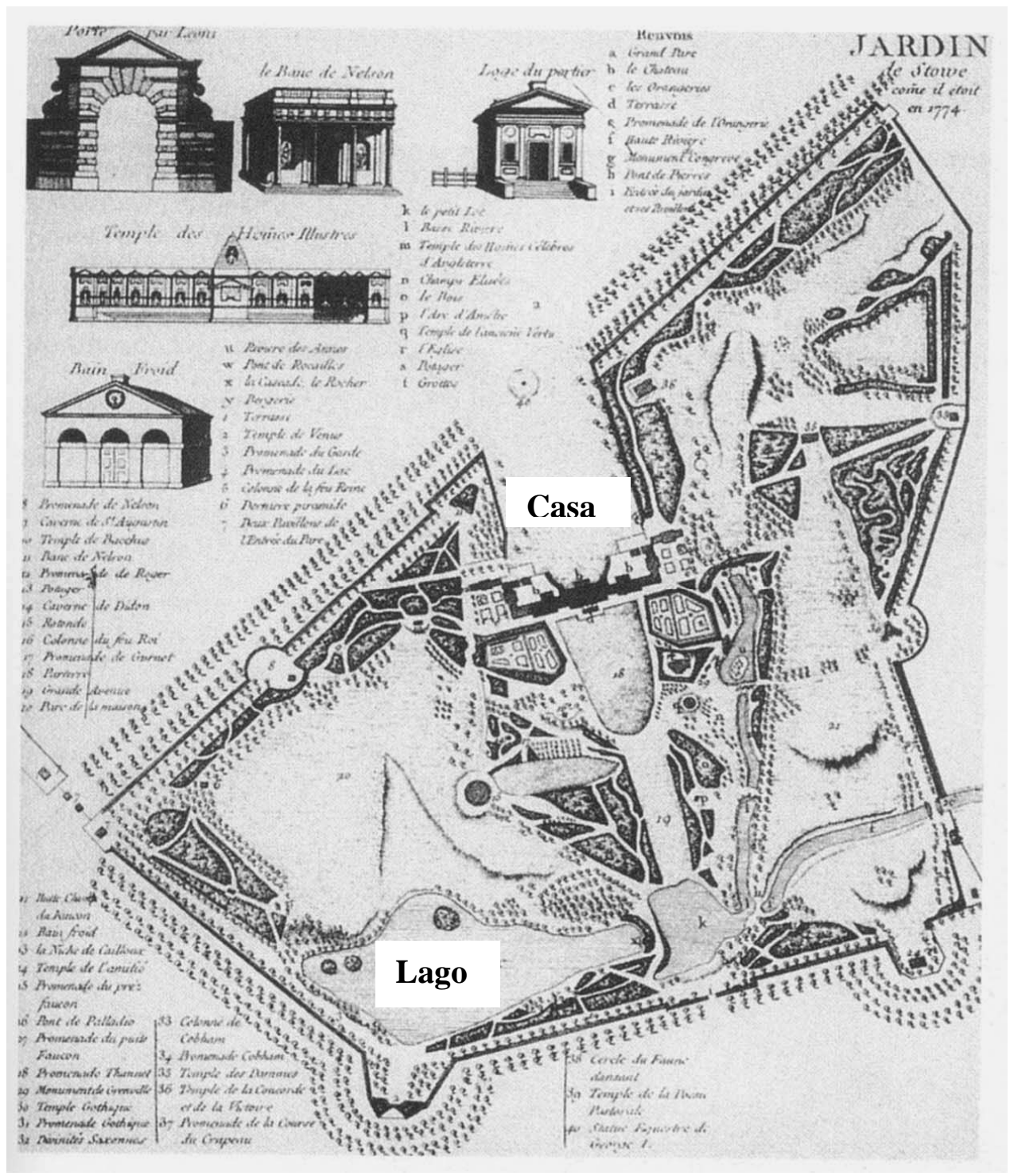

“Stowe: Plano geral de Le Rouge, 1774”.

Apesar de ser datado de um período posterior à publicação do romance, este desenho foi incluído por apresentar um detalhamento da mansão e dos jardins com o lago, os passeios e os canteiros, além de algumas construções que estão espalhadas pela propriedade. Pode-se notar a grande extensão do lago existente nas proximidades da mansão.

Fonte: Steenbergen \& Reh, 2001, p. 291. 


\section{BIBLIOGRAFIA}

ADORNO, Theodor W. "Posição do Narrador no Romance Contemporâneo". In: ADORNO, Theodor W. Notas de Literatura I. Tradução Jorge de Almeida. São Paulo, Duas Cidades:34, 2003. pp. 55-63.

ALLEN, Walter. The English Novel. London, Penguin, 1991.

ANTONIO CANDIDO. "A Personagem do Romance". In: ANTONIO CANDIDO et al. $A$ Personagem de Ficção. 10ed. São Paulo, Perspectiva, 2004. pp. 51-80.

ANTONIO CANDIDO. "O Direito à Literatura". In: ANTONIO CANDIDO. Vários Escritos. 4ed. Rio de Janeiro:Ouro sobre Azul; São Paulo:Duas Cidades, 2004. pp. 169191

ANTONIO CANDIDO. "O Homem dos Avessos". In: ANTONIO CANDIDO. Tese e Antítese. 5ed. Rio de Janeiro, Ouro sobre Azul, 2006. pp. 111-130.

ANTONIO CANDIDO. Formação da Literatura Brasileira: Momentos Decisivos 17501880. 10ed. Rio de Janeiro, Ouro sobre Azul, 2006.

ANTONIO CANDIDO. Literatura e Sociedade. 9ed. Rio de Janeiro, Ouro sobre Azul, 2006.

ANTONIO CANDIDO. O Discurso e a Cidade. 2ed. São Paulo, Duas Cidades, 1998.

ARIÈS, Phillippe. "Por uma História da Vida Privada". In: ARIÈS, Philippe \& CHARTIER, Roger, org. História da Vida Privada: da Renascença ao Século das Luzes. Tradução Hildegard Feist. São Paulo, Companhia das Letras, 2006. v. 3, pp.7-19.

ARMSTRONG, Nancy. Desire and Domestic Fiction: a Political History of the Novel. New York, Oxford University, 1987.

AUERBACH, Erich. Mimesis: a Representação da Realidade na Literatura Ocidental. 5ed. Vários Tradutores. São Paulo, Perspectiva, 2004.

BACHELARD, Gaston. A Poética do Espaço. Tradução Antonio de Pádua Danesi. São Paulo, Martins Fontes, 1993.

BAKHTIN, Mikhail. Questões de Literatura e de Estética: a Teoria do Romance. 5ed. Tradução Aurora Fornoni Bernardini et al. São Paulo, Hucitec:Annablume, 2002.

BENEDICT, Barbara M. "Readers, Writers, Reviewers and the Professionalization of Literature". In: KEYMER, Thomas \& MEE, Jon, ed. The Cambridge Companion to English Literature: 1740 - 1830. Cambridge, Cambridge University, 2004. pp. 03-23

BENJAMIN, Walter. Obras Escolhidas: Magia e Técnica, Arte e Política. Tradução Sergio Paulo Rouanet. São Paulo, Brasiliense, 1985. 
BOOTH, Wayne. The Rhetoric of Fiction. 2ed. Chicago, University of Chicago, 1983.

BRISSENDEN, R. F. Samuel Richardson. London, Longmans Green, 1965.

BRONTË, Charlotte. Jane Eyre. London, Penguin, 1994.

CHEVALIER, Jean. \& GHEERBRANT, Alain. Dicionário de Símbolos: mitos, sonhos, costumes, gestos, formas, figuras, cores, números. Tradução Vera da Costa e Silva et al. 21ed. Rio de Janeiro, José Olympio, 2007.

DIDEROT, Denis. “In Praise of Richardson”. In: DIDEROT, Denis. Selected Writings on Art and Literature. Tradução Geoffrey Bremner. London, Penguin, 1994. pp. 82-97.

DIMAS, Antonio. Espaço e Romance. 3ed. São Paulo, Ática, 1994.

DUNCAN EAVES, T. C. "Graphic Illustration of the Novels of Samuel Richardson: 17401810". The Huntington Library Quarterly. University of California, v.14, n.4, ago. 1951. pp. 349-383. Disponível em <http://www.jstor.org/stable/3816549>. Acesso em: $01 \mathrm{dez}$. 2008.

DUSSINGER, John A. "Ciceronian Eloquence: the Politics of Virtue in Richardson's Pamela”. In: BLEWETT, David. Passion and Virtue: Essays on the Novels of Samuel Richardson. Toronto, University of Toronto, 2001. pp. 27-51.

EAGLETON, Terry. Literary Theory: an Introduction. 2ed. Oxford, Blackwell, 2002.

EAGLETON, Terry. The Function of Criticism: from the Spectator to Post-Structuralism. London, Verso, 1984.

ELIOT, T. S. "Tradition and the Individual Talent". In: ELIOT, T. S. Selected Essays. London, Faber and Faber, 1991. pp. 13-22.

FIELDING, Henry. Joseph Andrews / Shamela. London, Penguin, 1999.

FLETCHER, Banister. A History of Architecture on the Comparative Method. 16 ed. London, Batsford, 1956.

FOLKENFLIK, Robert. “A Room of Pamela's Own”. ELH. Johns Hopkins University, v.39, n.4, dez. 1972. pp. 585-596. Disponível em <http://www.jstor.org/stable/2872701>. Acesso em: 01 dez. 2008.

FRIEDMAN, Norman. "O Ponto de Vista na Ficção: o Desenvolvimento de um Conceito Crítico". Revista USP. São Paulo, n. 53, março / maio 2002. pp. 166-182.

HAUSER, Arnold. História Social da Literatura e da Arte. São Paulo, Mestre Jou, 1973.

KEYMER, Tom. Richardson's Clarissa and the Eighteenth-Century Reader. Cambridge, Cambridge University, 1992.

LEITE, Ligia Chiappini Moraes. O Foco Narrativo: ou a Polêmica em Torno da Ilusão. 10ed. São Paulo, Ática, 2005. 
LEITES, Edmund. A Consciência Puritana e a sexualidade moderna. Tradução Elide Valarini. São Paulo, Brasiliense, 1987.

LINS, Osman. Lima Barreto e o Espaço Romanesco. São Paulo, Ática, 1976.

LIPSEDGE, Karen. "A Place of Refuge, Seduction or Danger? The Representation of the Ivy Summer-House in Samuel Richardson's Clarissa". Journal of Design History. Oxford University, v.19, n.3, Ago. 2006. pp. 185-196. Disponível em <http://www.jstor.org/stable/4123027>. Acesso em: 01 dez. 2008.

LOTMAN, Iuri. A Estrutura do Texto Artístico. Tradução Maria do Carmo V. Raposo e Alberto Raposo. Lisboa, Estampa, 1978.

LUKÁCS, Georg. "Narrar ou descrever". In: LUKÁCS, Georg. Ensaios sobre Literatura. Rio de Janeiro, Civilização Brasileira, 1965.

LUKÀCS, Georg. "O Romance como Epopéia Burguesa". Revista Ensaios Ad Hominem. São Paulo, n.1, t.II, 1999. pp. 87-117.

LUKÁCS, Georg. A Teoria do Romance. Tradução José Marcos Mariani de Macedo. São Paulo, Duas Cidades:34, 2000.

MACFARLANE, Alan. The Origins of English Individualism: the Family, Property and Social Transition. Oxford, Basil Blackwell, 1989.

MANNING, Susan. "Sensibility". In: KEYMER, Thomas \& MEE, Jon, ed. The Cambridge Companion to English Literature: 1740 - 1830. Cambridge, Cambridge University, 2004. pp. 80-99

MCINTOSH, Carey. "Pamela's Clothes". ELH. Johns Hopkins University, v.35, n.1, mar. 1968. pp. 75-83. Disponível em <http://www.jstor.org/stable/2872337>. Acesso em: 01 dez. 2008.

MCKEON, Michael. The Origins of the English Novel: 1600-1740. $15^{\text {th }}$ anniversary edition. Baltimore, John Hopkins, 2002.

PERNIOLA, Mario. "Expansão e fragmentação do horizonte estético". Tradução Vitor Moura. Revista Diacrítica: Filosofia e Cultura. Universidade do Minho, n. 20/2, 2006. pp. 107-118.

PIERCE, John B. "Pamela's Textual Authority". In: BLEWETT, David. Passion and Virtue: Essays on the Novels of Samuel Richardson. Toronto, University of Toronto, 2001. pp. 8-26.

POULET, Georges. O Espaço Proustiano. Tradução Ana Luiza B. Martins Costa. Rio de Janeiro, Imago, 1992.

RAYNIE, Stephen A. "Hayman and Gravelot's Anti-Pamela Designs for Richardson's Octavo Edition of Pamela I and II". Eighteenth Century Life. Duke University, v.23, n.3, nov. 1999. pp.77-93. Disponível em: <http://muse.jhu.edu/journals/eighteenthcentury_life/v023/23.raynie.html>. Acesso em: 23 jul. 2009. 
RICHARDSON, Samuel. Pamela, or Virtue Rewarded. London, Penguin, 1985.

ROSENFELD, Anatol. "Literatura e personagem". In: ANTONIO CANDIDO et al. A Personagem de Ficção. 10ed. São Paulo, Perspectiva, 2004. pp. 09-49.

ROSENFELD, Anatol. O Teatro Épico. Rio de Janeiro, Ao livro técnico, 1965.

SABOR, Peter. "Richardson, Henry Fielding and Sarah Fielding". In: KEYMER, Thomas \& MEE, Jon, ed. The Cambridge Companion to English Literature: 1740 - 1830. Cambridge, Cambridge University, 2004. pp. 139-156.

SAMBROOK, James. The Eighteenth Century: The Intellectual and Cultural Context of English Literature 1700 - 1789. 2ed. London, Longman, 1994.

SANTOS, Milton. A Natureza do Espaço: Técnica e Tempo, Razão e Emoção. São Paulo, Edusp, 2002.

SANTOS, Milton. Por uma Geografia Nova: da Crítica da Geografia a uma Geografia Crítica. 2ed. São Paulo, Hucitec, 1980.

SCHWARZ, Roberto. Um Mestre na Periferia do Capitalismo. São Paulo, 34, 2000.

SHERBURN, George \& BOND, Donald F. The Restoration and Eighteenth Century 16601789. 2ed. London, Routledge, 1993.

SPACKS, Patricia Ann Meyer. Privacy: Concealing the Eighteenth-Century Self. Chicago, University of Chicago, 2003.

STEENBERGEN, Clemens \& REH, Wouter. Arquitectura y paisaje: la proyectación de los grandes jardines europeos. Barcelona, Gustavo Gili, 2001.

TODD, Janet. Sensibility: an Introduction. London, Methuen, 1986.

VAN SANT, Ann Jessie. Eighteenth-Century Sensibility and the Novel: the Senses in Social Context. Cambridge, Cambridge University, 1993.

VAREY, Simon. Space and the Eighteenth-century English Novel. Cambridge, Cambridge University, 1990.

VASCONCELOS, Sandra G. A Formação do Romance Inglês: Ensaios Teóricos. São Paulo, Aderaldo \& Rothschild:Fapesp, 2007.

VASCONCELOS, Sandra G. Dez Lições sobre o Romance Inglês do Século XVIII. São Paulo, Boitempo, 2002.

WATT, Ian. The Rise of the Novel: Studies in Defoe, Richardson and Fielding. London, Pimlico, 2000.

WOOLF. Virginia. A Room of One's Own. London, Penguin, 2004. 